INSTITUTO DE PESQUISAS ENERGÉTICAS E NUCLEARES

Autarquia associada à Universidade de São Paulo

Estudo in-vitro dos efeitos do laser de Er,Cr:YSGG em tecido ósseo por espectroscopia ATR-FTIR

\author{
CAROLINA BENETTI
}

Dissertação como parte dos requisitos para obtenção do Grau de Mestre em Ciências na Área de Tecnologia Nuclear - Materiais.

Orientadora:

Profa. Dra.Denise Maria Zezell

SÃO PAULO 
INSTITUTO DE PESQUISAS ENERGÉTICAS E NUCLEARES

Autarquia associada à Universidade de São Paulo

Estudo in-vitro dos efeitos do laser de Er,Cr:YSGG em tecido ósseo por espectroscopia ATR-FTIR

\author{
CAROLINA BENETTI
}

Dissertação como parte dos requisitos para obtenção do Grau de Mestre em Ciências na Área de Tecnologia Nuclear - Materiais.

Orientadora:

Profa. Dra.Denise Maria Zezell 


\section{DEDICATÓRIA}

A todas as pessoas que tornaram o caminho até aqui mais brando. Anônimos por serem muitos, inesquecíveis por serem poucos. Meu agradecimento a vocês não seria o suficiente, por isso dedico o maior dos resultados dos meus dois anos de trabalho: essa dissertação.

Obrigada pela ajuda, amizade e carinho todos vocês. 


\section{AGRADECIMENTOS}

Aos meus pais, Regina Maria Bovo e Paulo Andrea Benetti, pessoas que admiro e me espelho. Obrigada por me ensinarem o valor do conhecimento e do trabalho; por me apoiarem e incentivarem nos caminhos em que eu escolhi seguir; pelo amor e carinho com que pude e posso contar em todos os momentos da minha vida.

Ao meu namorado, Thiago. Simplesmente não consigo achar as palavras para agradecer. Obrigada por estar ao meu lado quando eu precisei; por dizer que eu podia ir além, quando eu achava que estava no limite; por acreditar que tudo ia dar certo, quando tudo estava dando errado; a sua amizade e incentivo foram essenciais.

À minha irmã, Mariane, primeira amiga que tive no mundo, e com quem sempre posso contar;

Aos meus avós, Lourdes, Maria, Oswaldo e Bruno, pelo amor que só os avós são capazes de dar;

À minha tia, Denise, pela amizade, apoio, e auxilio no meu primeiro projeto de iniciação;

Aos demais membros da minha família: Claudia, Edgar, Paulo e Ricardo, que de forma direta ou indireta ajudaram na realização deste trabalho;

À família de Angelis, por todo carinho e apoio;

À Profa. Dra. Denise Maria Zezell, por exercer tão importante papel na minha formação, desde minha graduação pacientemente me orientando. Agradeço toda dedicação, carinho, e amizade neste quase cinco anos de convivência. Acredito que minha satisfação e elogios estão representados no desejo de continuar a ser sua orientada no Doutorado;

À Prof. Dra. Patrícia da Ana, por todos os conselhos, recomendações, e principalmente pela alegria e paciência com que sempre me ajudou. Sua competência, e dedicação são uma inspiração.

Ao Prof. Dr. Luciano Bachmann, por todas as discussões, ajudas, e conselhos; 
A Profa. Dra. Luciana pela ajuda e atenção nos primeiros passos deste projeto, e por sua participação no Exame de Qualificação;

A Profa. Dra. Sônia e ao Prof. Dr. Laércio, pelas recomendações e participação na banca do seminário de área;

Ao Msc. Marcos (Magá) pela ajuda e futura ajuda nos procedimentos cirúrgicos; seu interesse, dedicação e profissionalismo são um exemplo.

Aos meus amigos do laboratório e companhia: Andrezza, Claudinha, Cacau, Strefezza, Felipe, Juca, Quinto, Moisés, Thiago e Vivi, pela ajuda, companheirismo, e amizade. Sem a presença de vocês e as indescritíveis situações que vivemos juntos, grande parte da alegria desta jornada seria perdida;

Aos meus colegas de sala: Eliane, Ilka, Marcello, Marcus, Melissa e Renato por todas as conversas e discussões, algumas até de caráter cientifico;

Ao Valdir, pela ajuda prestada no laboratório e principalmente nas comemorações;

Aos demais alunos do CLA, pelas experiências, dificuldades, e vitórias compartilhadas;

À todos os pesquisadores do CLA, por contribuírem de diversas formas em diversas etapas deste projeto;

Aos funcionários da CPG, pelos serviços e auxílio prestados;

Aos demais funcionários e técnicos do CLA, em especial a Dona Nena, Seu Luiz e Rubens, por realizarem seu serviço com excelência e principalmente bom humor;

Ao Biotério da Faculdade de Medica da USP pelos serviços prestados;

À CAPES pela bolsa de mestrado concedida;

A FAPESP, CNPq, CePOF por financiarem os projetos de pesquisa associados a esse trabalho; 
"Se você tem que se sustentar, é melhor achar uma ocupação que seja interessante."

Katherine Herburn 


\title{
ESTUDOS IN VITRO DOS EFEITOS DO LASER DE Er,Cr:YSGG EM TECIDO ÓSSEO POR ESPECTROSCOPIA ATR-FTIR
}

\author{
CAROLINA BENETTI
}

\begin{abstract}
RESUMO
O laser tem se mostrado eficaz no auxílio ao profissional de saúde, sendo extensivamente utilizado em procedimentos médicos e odontológicos nas ultimas décadas. Em particular, os lasers de alta intensidade emissores no infravermelho possuem grande potencial para corte de tecidos biológicos mineralizados, visto que são bastante absorvidos pela hidroxiapatita e água, principais componentes desses tecidos. Em comparação aos instrumentos mecânicos, o laser apresenta uma série de vantagens no corte de tecidos, com possibilidade de menor dano ao tecido remanescente e melhor hemostasia. Entretanto, para uma aplicação eficiente e segura é necessário conhecer os efeitos que a irradiação laser causa ao tecido. A técnica de espectroscopia no Infravermelho por Transformada de Fourier (FTIR) é bastante utilizada no estudo de materiais orgânicos, pois além de permitir a identificação de componentes, possibilita uma análise semiquantitativa. Este trabalho tem como objetivos estabelecer a técnica de ATR-FTIR para caracterização do tecido ósseo natural e irradiado, e verificar as eventuais mudanças químicas e estruturais causadas pela irradiação laser. Primeiramente, foram determinadas as melhores condições instrumentais para a obtenção dos espectros de amostras de osso. Posteriormente foram analisadas as amostras de osso natural e irradiado com o laser de Er,Cr:YSGG $(2,78 \mu \mathrm{m})$ com diferentes densidades de energia. Verificou-se que a técnica foi eficaz na caracterização do tecido ósseo, sendo possível observar as alterações químicas promovidas pelo aumento de temperatura ocasionado pela irradiação laser. Foi observada a perda gradativa de material orgânico em função do aumento da densidade de energia utilizada. Os resultados obidos são os primeiros passos para a verificação da eficácia do laser de Er,Cr:YSGG quando empregado como uma ferramenta de corte, essencial para sua consolidação na prática clínica.
\end{abstract}




\title{
STUDY IN VITRO OF Er,Cr:YSGG LASER EFFECTS IN BONE TISSUE BY ATR-FTIR SPECTROSCOPY
}

\author{
CAROLINA BENETTI
}

\begin{abstract}
Laser proves to be, more and more, an effective tool for helping health professionals, being intensively used in ophthalmological and odontological procedures. In particular, high-density, infrared emitting lasers have great potential in cutting mineralized biological hard tissues, given their high absorption by hydroxyapatite and water, these tissues' main components. In comparison to mechanical instruments, laser presents a series of advantages, namely, smaller damage to the remaining tissue and promotion of homeostatic effect, apart from making it possible to execute procedures in areas with difficult access. However, for an efficient and safe use of this technique, it is necessary to know the effects of the laser irradiation on the tissue. The Fourier transform infrared (FTIR) technique is heavily used in the study of organic materials, because apart from making it possible to identify the materials' components, it also allows to prepare a semi quantitative analysis. This work aims to establish the ATR-FTIR technique in the characterization of natural and irradiated osseous tissue, and to verify the possible chemical and structural changes caused by irradiation. Firstly, the best conditions for the obtainment of bone sample spectra were determined. Then, bone samples, irradiated with the Er,Cr:YSGG $(2,78 \mu \mathrm{m})$ infrared emitting laser (adjusted with different energy densities) were analyzed alongside with natural bone samples. It has been verified that the technique is effective in the bone tissue characterization, and that it is possible to observe the chemical changes caused by the temperature rise due to laser irradiation. It has been observed a gradual organic material loss as the energy density goes up. These results are the first steps in testing the Er,Cr:YSGG laser efficacy as a cutting tool, a pivotal aspect of its consolidation in clinical procedures.
\end{abstract}


1. INTRODUÇÃO............................................................................. 11

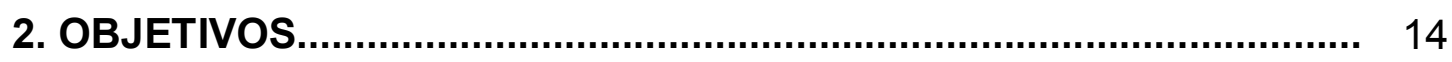

3. REVISÃO DA LITERATURA........................................................ 15

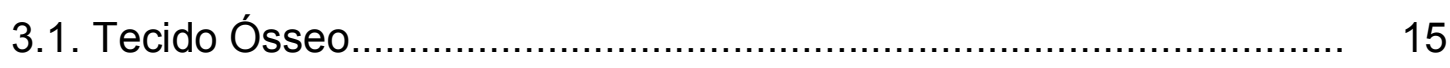

3.2. O Laser como Ferramenta de Corte Ósseo.................................... 17

3.3. Espectroscopia no Infravermelho por transformada de Fourier... 22

3.3.1. Radiação Eletromagnética................................................... 22

3.3.2. Técnicas Espectroscópicas................................................. 23

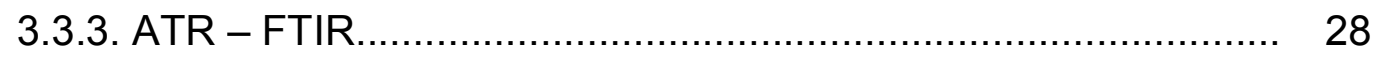

3.4. Espectroscopia FTIR na análise de tecidos biológicos

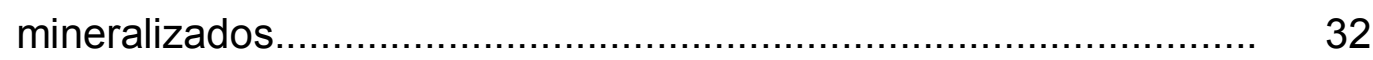

3.4.1. Bandas de Absorção......................................................... 33

4. MATERIAL E MÉTODOS............................................................ 39

4.1. Preparação das amostras........................................................... 39

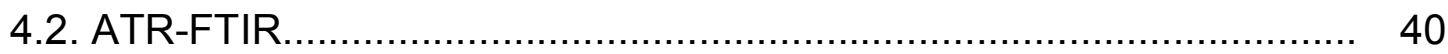

4.3. Determinação dos parâmetros do ATR-FTIR ................................. 42

4.3.1. Detector e Beamsplitter..................................................... 42

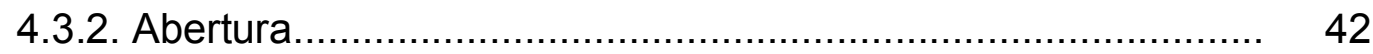

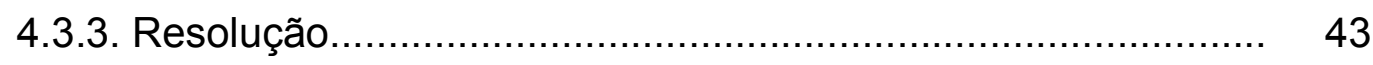

4.3.4. Número de varreduras..................................................... 45 
4.3.5. Velocidade do espelho..................................................... 47

4.4. Obtenção dos Espectros.............................................................. 47

4.4.1 Amostras não irradiadas..................................................... 47

4.4.2. Amostras irradiadas com laser de Er,Cr:YSGG.................... 48

4.5. Estudo das formas de analise dos espectros................................. 51

4.5.1. Identificação das Bandas.................................................... 51

4.5.2. Reprodutibilidade do Espectro........................................... 52

4.5.3. Normalização dos Espectros.............................................. 52

4.5.4. Definição das posições das bandas......................................... 52

4.5.5. Cálculo da área das bandas................................................ 53

4.5.6. Método estatístico....................................................... 55

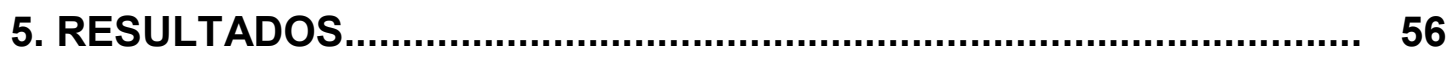

5.1. Parâmetros do ATR-FTIR .............................................................. 56

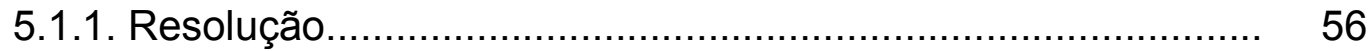

5.1.2. Número de varreduras................................................... 59

5.1.3. Velocidade do espelho..................................................... 61

5.2. Identificação das Bandas........................................................... 61

5.3. Estudo das formas de análise dos espectros................................. 70

5.3.1. Reprodutibilidade do Espectro............................................. 70

5.3.2. Normalização do espectro................................................... 73

5.3.3. Determinação da posição das bandas..................................... 78

5.3.4 Calculo da área sob as bandas.......................................... 79 
5.4. Amostras irradiadas.............................................................. 81

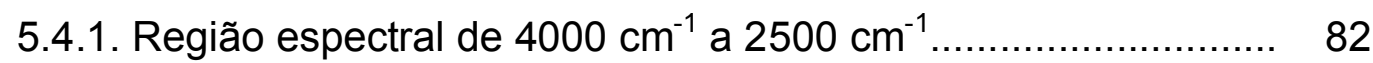

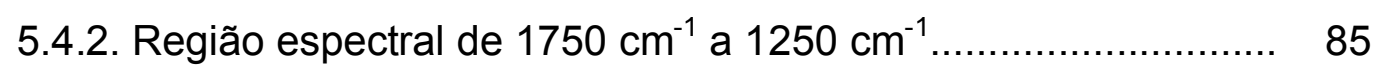

5.4.3. Região espectral de $1300 \mathrm{~cm}^{-1}$ a $1180 \mathrm{~cm}^{-1} \ldots \ldots \ldots \ldots \ldots \ldots \ldots \ldots . . . \ldots 1$

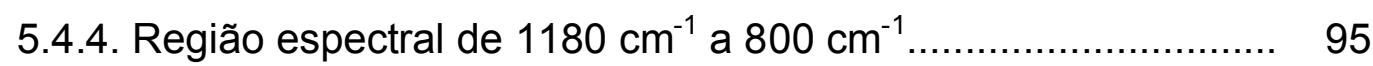

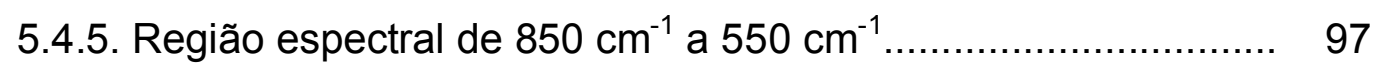

6. DISCUSSÂO................................................................................ 101

6.1. Considerações Gerais................................................. 101

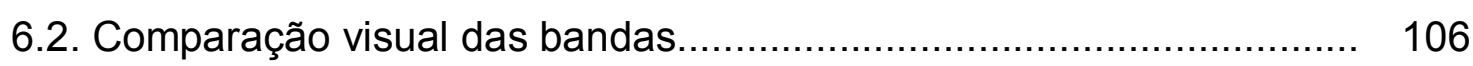

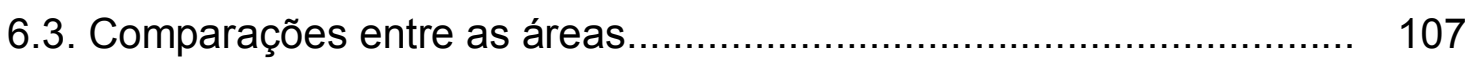

7. CONCLUSÃO....................................................................... 113

ANEXO A - Principais publicações e prêmios referentes ao trabalho desenvolvido.......................................................................... 114

REFERÊNCIAS BIBLIOGRÁFICAS.................................. 115 


\section{INTRODUÇÃO}

O corte ósseo é frequentemente realizado durante os procedimentos cirúrgicos, seja por motivos de acesso a regiões subjacentes ou por motivos terapêuticos inerentes ao próprio tecido ${ }^{1}$. Entretanto, as ferramentas de corte tradicionais e ainda amplamente utilizadas, tais como os instrumentos rotatórios em alta e baixa rotação, muitas vezes acabam por retardar o período pósoperatório do paciente, pois muitas vezes podem causar traumas mecânicos, aumento excessivo de temperatura local, hemorragias excessivas que dificultam a visualização do profissional ${ }^{2,3,4}$. Uma das alternativas para o corte de tecidos duros e moles é a irradiação laser.

O laser é extensivamente utilizado em procedimentos clínicos médicos e odontológicos ${ }^{5,6}$, sendo, neste último caso, utilizado para realização de preparo cavitário, prevenção de cáries, desinfecções, corte de tecidos moles, dentre outros $^{5,7,8}$. O potencial dos lasers emissores no infravermelho na ablação de tecidos biológicos mineralizados já é amplamente estabelecido e reconhecido na literatura $^{4}$. O laser de Er,Cr:YSGG com comprimento de onda de 2,78 $\mu \mathrm{m}$ é fortemente absorvido pela água e hidroxiapatita ${ }^{1,5,7,8,9}$, os principais componentes da dentina e ossos ${ }^{5,10}$. Desta maneira, sua forte interação promove cortes precisos e com rapidez, além de apresentar segurança quanto aos efeitos térmicos promovidos. Entre as vantagens que o laser oferece em relação aos instrumentos de corte tradicionais destacam-se a maior precisão de corte, maior hemostasia, a possibilidade de cortar tecidos em área de difícil acesso, além de minimizar danos mecânicos e térmicos ${ }^{2,4,7,9,11}$.

$\mathrm{Na}$ literatura há uma grande variedade de estudos sobre os efeitos da irradiação do laser de Er,Cr:YSGG com os tecidos duros dentários ${ }^{5}$, assim como durante o corte ósseo ${ }^{1,4,7,9}$. Normalmente, os estudos são focados nas mudanças morfológicas e histológicas promovidas pelas irradiações ${ }^{1,4,7}$, havendo a necessidade de melhor analisar os efeitos da irradiação laser no tecido ósseo do ponto de vista químico e estrutural. 
Nos últimos anos, a espectroscopia no infravermelho por transformada de Fourier (FTIR) vem sendo extensivamente utilizada na análise de materiais orgânicos. Essa técnica permite identificar os componentes da amostra analisada, possibilitando uma análise semiquantitativa, além de fornecer informações químicas e estruturais do material ${ }^{12,13,14}$. Dentre as técnicas de espectroscopia no infravermelho existentes, a que utiliza o efeito da reflexão total atenuada (ATR) é a mais indicada para a análise de amostras sólidas por possibilitar a obtenção de espectros qualitativos independentemente da espessura da amostra ${ }^{15}$.

A espectroscopia no infravermelho já foi utilizada na caracterização de tecido dental duro irradiado ${ }^{13,16,17,18}$,onde a técnica se mostrou capaz de detectar as mudanças composicionais causadas pela irradiação laser. Ela também já foi utilizada na caracterização do tecido ósseo para diversas finalidades, como: na diferenciação de tecidos saudáveis e cancerígenos ${ }^{19,20}$ na análise das modificações causadas com o envelhecimento do osso $^{21}$, no estudo da $o_{\text {osteoporose }}{ }^{22}$. Entretanto, por se tratar de uma técnica relativamente nova ${ }^{18}$, ainda existem muitos aspectos da interação laser tecido que podem ser explorados por esta técnica.

Estudos prévios realizados em tecido dental irradiado demonstraram que a irradiação laser provoca perda de material orgânico e mudança na cristalinidade do tecido, sendo estas alterações maiores quanto maior a densidade de energia utilizada $^{13,16,17}$. Nas estruturas dentais, essas alterações afetam a resistência do dente à desmineralização e consequentemente sua resistência à cárie ${ }^{23,24}$. No tecido ósseo, uma alteração significativa de material orgânico pode retardar o processo de regeneração ${ }^{14}$, além de poder torná-lo mais quebradiço, visto que a dureza e resistência do tecido ósseo se dão pela associação das fibras colágenas e hidroxiapatita ${ }^{25}$.

Considerando que ainda não há um protocolo específico para o emprego do laser de Er,Cr:YSGG para o corte de tecido ósseo, torna-se importante caracterizar este tecido após sua irradiação com o laser de Er,Cr:YSGG com diferentes densidades de energia. A técnica de ATR-FTIR é sugerida para esta 
análise, que representa um passo importante para consolidar o laser de Er,Cr:YSGG como uma ferramenta segura para o corte ósseo. 


\section{OBJETIVOS}

Este trabalho pretende desenvolver uma metodologia de avaliação das mudanças composicionais por espectroscopia no infravermelho por transformada de Fourier, ocorridas em amostras de tecido ósseo quando irradiados com laser de Er,Cr:YSGG.

Os objetivos específicos são:

- Determinar as condições de obtenção dos espectros, otimizando a qualidade de sinal usando a técnica ATR-FTIR;

- Avaliar os efeitos composicionais causados em tecido ósseo irradiado com diferentes densidades de energia. 


\section{REVISÃO DA LITERATURA}

Nesta seção procurou-se esclarecer os detalhes sobre a técnica de análise empregada, além de contextualizar o que já se conhece sobre a interação laser com o tecido.

\subsection{Tecido Ósseo ${ }^{25}$}

O tecido ósseo é um tipo especializado de tecido conjuntivo, formado por células (osteócitos, osteoblastos, e osteoclastos), e material extracelular calcificado (a matriz óssea). Entre suas funções estão: suporte para as partes moles, proteção de órgãos vitais, alojamento e proteção da medula óssea, proporcionar apoio aos músculos, além de funcionar como depósito de cálcio, fosfato e outros íons. Em relação ao seu peso, a composição do tecido ósseo é: 20 - 30\% de material orgânico (principalmente colágeno); de $60-70 \%$ de material inorgânico; e $10 \%$ de água ${ }^{26}$.

As principais células do tecido ósseo são: os osteoclastos, responsáveis pela reabsorção e remodelação dos ossos; os osteoblastos, que sintetizam a parte orgânica da matriz óssea, além de participarem da sua mineralização; e os osteócitos, essenciais para a manutenção da matriz óssea.

A parte inorgânica da matriz óssea é formada principalmente por íons de fosfato e cálcio que formam cristais de hidroxiapatita - $\mathrm{Ca}_{10}\left(\mathrm{PO}_{4}\right)_{5}(\mathrm{OH})_{2}$, além de íons de bicarbonato, magnésio, potássio, sódio, e citrato em pouca quantidade.

A parte orgânica da matriz óssea é formada $95 \%$ por fibras colágenas, constituídas principalmente por colágeno tipo I, além de pequenas quantidades de outras proteínas.

A dureza e resistência do tecido ósseo ocorrem pela associação das fibras colágenas e hidroxiapatita. Ocorrendo a destruição da parte orgânica da matriz óssea o tecido mantém sua forma intacta, porém torna-se quebradiço e de difícil 
manipulação. Se ocorrer perda de cálcio, o tecido fica intacto, mas torna-se borrachudo.

Macroscopicamente o tecido ósseo é dividido em ossos compactos e esponjosos. O tecido ósseo esponjoso apresenta lacunas em sua matriz, enquanto que o tecido ósseo compacto não. Por sua forma os ossos são divididos em longos, curtos, e chatos. Os ossos curtos têm seu centro composto de tecido ósseo esponjoso, sendo sua periferia recoberta com uma camada de tecido ósseo compactado. Os ossos longos têm suas extremidades (epífises) formadas por ossos esponjosos, e a parte cilíndrica (diáfise) é quase totalmente formada por osso compacto - osso cortical, havendo uma pequena quantidade de osso esponjoso na região mais interna, na interface do canal medular.

Histologicamente o tecido ósseo é classificado por imaturo ou primário, e maduro ou secundário (ou ainda lamelar). A classificação se dá devido à diferença da organização das fibras colágenas: enquanto no primário elas não apresentam disposição regular, no secundário estão organizadas em lamelas. 0 tecido ósseo primário está presente no desenvolvimento embrionário, e na reparação de fratura. É um tecido temporário, sendo substituído gradativamente pelo tecido ósseo secundário e, por isso, é pouco frequente em ossos de adultos. Ente suas características destacam-se as fibras colágenas sem organização definida, a menor quantidade de minerais e a maior proporção de osteócitos em comparação com o tecido ósseo secundário. No tecido ósseo secundário as fibras colágenas estão organizadas em lamelas ou paralelas uma às outras em camadas concêntricas em torno de canais com vasos, formando os sistemas de Havers ou Ósteons (FIG. 1). 


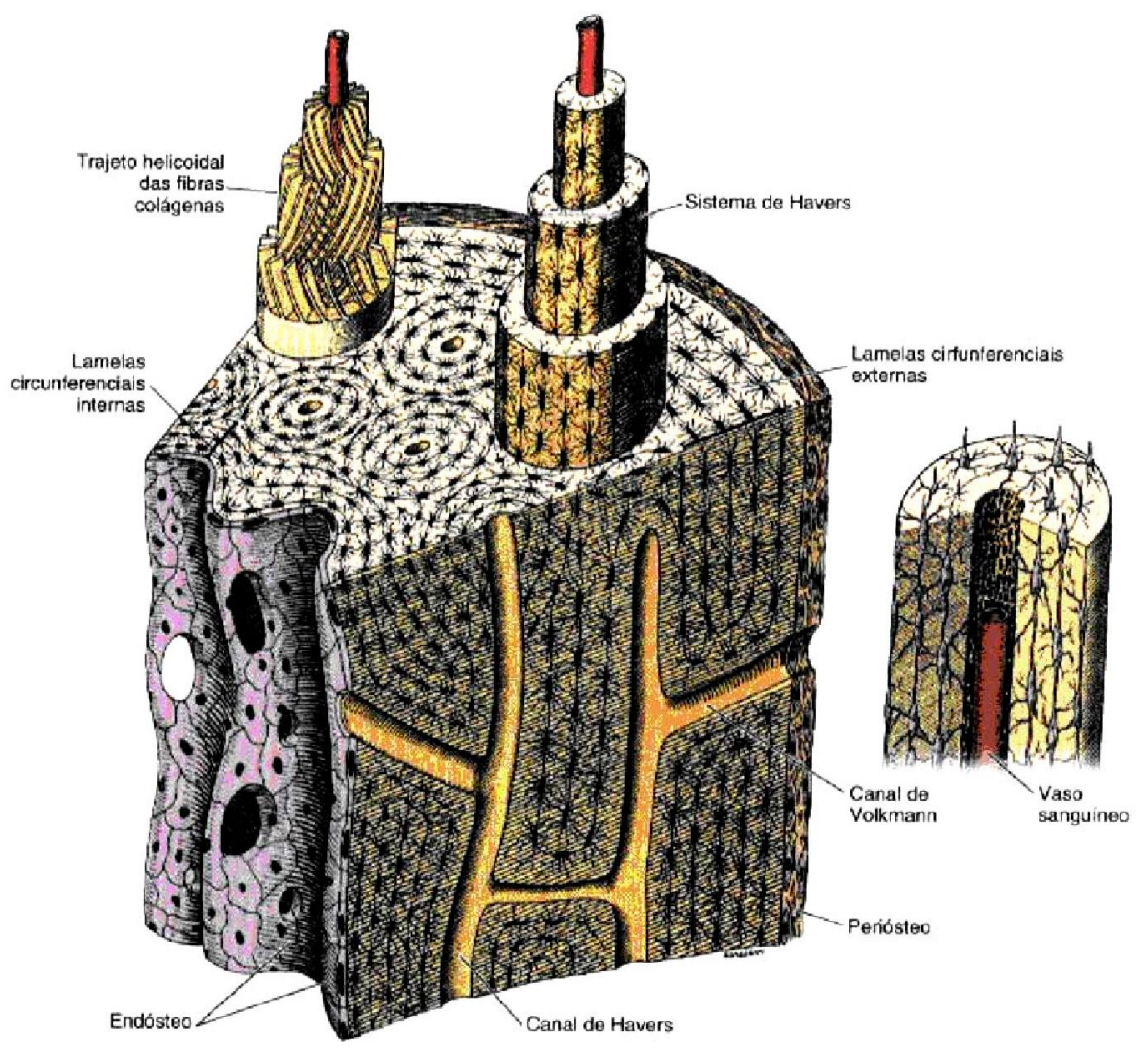

FIGURA 1 - Imagem do tecido ósseo longo com a identificação de suas partes ${ }^{25}$

Neste trabalho o osso estudo foi a parte cortical da tíbia de coelhos adultos, portanto um osso compacto, longo, e secundário (FIG. 1).

\subsection{O Laser como Ferramenta de Corte Ósseo}

Em diversos procedimentos médicos e odontológicos, como em cirurgias ortognaticas, ortopédicas e bucomaxilofacial, o corte ósseo é necessário, seja para permitir o acesso a uma região, ou devido à necessidade da remodelação, desgaste ou remoção do tecido ${ }^{1}$. Os instrumentos cortantes utilizados atualmente como brocas, e serras (FIG. 2) causam traumas mecânicos e aumento de temperatura ao tecido ósseo ${ }^{27}$, devido ao atrito entre o metal com o tecido. Em alguns casos, ocorre a deposição de partículas metálicas no tecido remanescente, o que prejudica o processo regenerativo ${ }^{2,3}$. O corte em regiões com acesso limitado é dificultado devido ao tamanho dos equipamentos, e a baixa precisão de corte faz com que mais tecido do que o necessário seja removido ${ }^{4}$. 
(A)

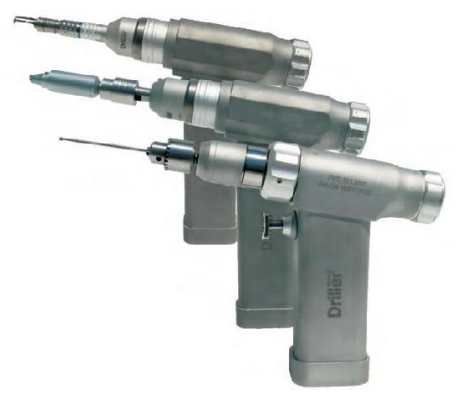

(B)

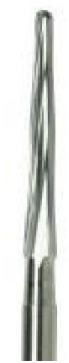

FIGURA 2 - Instrumentos para o corte ósseo utilizados atualmente: (A) motores elétricos $^{28}$ (B) ponta diamantada ${ }^{29}$.

Os lasers são uma possível alternativa para a realização do corte ósseo, pois apresentam vantagens em relação aos instrumentos atuais, como: maior facilidade no alcance de regiões de difícil acesso ${ }^{11}$; maior precisão de corte, devido ao pequeno diâmetro do feixe ${ }^{9}$; menor aumento de temperatura e choque mecânico ${ }^{7}$; e menor sangramento ${ }^{30}$.

Os primeiros estudos utilizando o laser no corte de tecido datam de $1964^{9}$. Desde então diversos trabalhos foram publicados utilizando diferentes lasers para o corte e remoção de tecido mineralizados duros. Muitos estudos foram realizados utilizando-se os lasers $\mathrm{Ho}: \mathrm{YAG}^{31}$, Nd:YAG e $\mathrm{CO}_{2}{ }^{32}$ para a remoção e desgaste de tecidos mineralizados duros, entretanto, sinais de dano térmico como carbonização e necrose do tecido remanescente, e também atraso no processo de regeneração óssea, foram observados ${ }^{31,32}$.

A interação da luz laser com os tecidos biológicos depende das propriedades óticas e térmicas do tecido, principalmente, o coeficiente de absorção e espalhamento; e dos parâmetros do laser, como comprimento de onda, modo de emissão (continuo ou pulsado), energia do pulso, densidade de energia, tempo do pulso, entre outros. Ao incidir sobre o material, a luz pode sofrer reflexão, transmissão, espalhamento e absorção, conforme ilustrado na FIG. 3, sendo o ultimo fundamental na interação da luz com tecidos biológicos, já que é neste processo que ocorre a transferência de energia para o tecido ${ }^{33}$, 


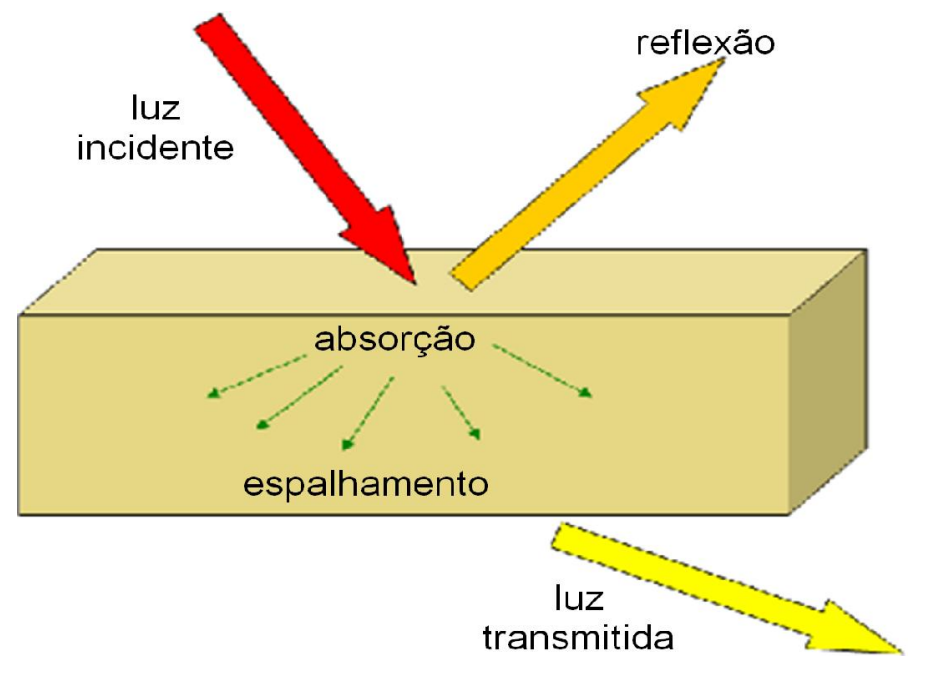

FIG 3 - Interações da luz com a matéria

Atualmente, sabe-se que o potencial da utilização do laser para realização de cortes ósseos está principalmente relacionado com o seu comprimento de onda, densidade de energia, e refrigeração com água e ar da amostra durante a irradiação, visto que o uso de diferentes parâmetros resulta em resultados contrastantes no processo de regeneração óssea ${ }^{34},{ }^{35}$. Os laser emissores no infravermelho como o Er:YAG $(2,94 \mu \mathrm{m})$ e Er,Cr:YSGG $(2,78 \mu \mathrm{m})$ apresentam um grande potencial de uso, visto que são fortemente absorvidos pelos principais componentes dos tecidos mineralizados duros, como pode ser visto na FIG. 4 


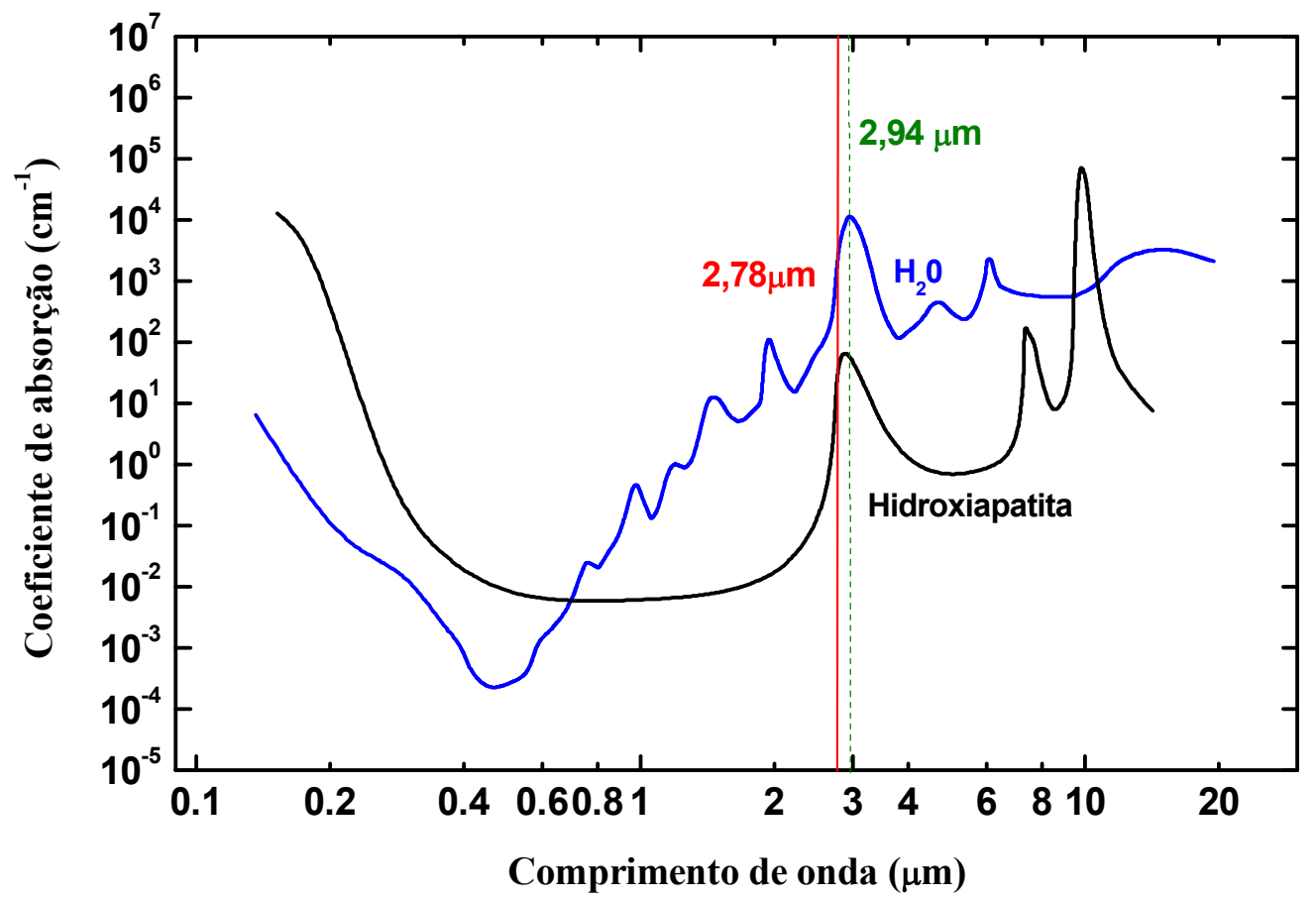

FIGURA 4 - Espectro de absorção dos hidroxiapatita e água ${ }^{8}$.

Os lasers emissores no infravermelho promovem remoção de tecido mineralizados pelo processo de ablação térmica. Nele, a energia depositada pelo laser é absorvida pela água presente no material, aumentando sua temperatura. A água entra em ebulição, e aumenta a pressão interna do tecido, gerando uma microexplosão que causa a remoção de material, resultando em uma cratera de ablação ${ }^{36}$. A FIG. 5 ilustra o processo de ablação explosiva.

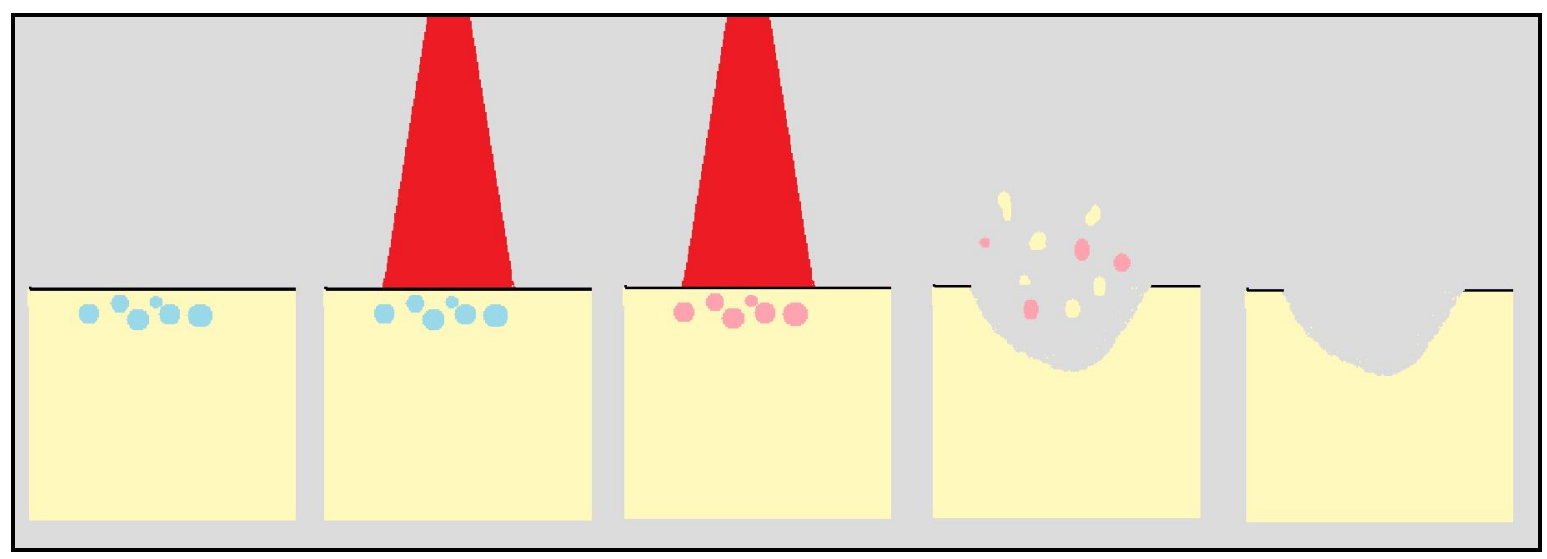

FIGURA 5 - Ilustração do processo de ablação explosiva 
Os lasers de Er:YAG $(2,94 \mu \mathrm{m})$ e Er,Cr:YSGG $(2,78 \mu \mathrm{m})$, por serem fortemente absorvidos pela água, fazem com que o processo de ablação ocorra rapidamente, causando menor danos térmicos ao tecido adjacente. Entretanto, para ocorrer ablação, não basta que o laser seja fortemente absorvido pela água. É necessário que ele tenha densidade de energia grande o suficiente. Chama-se de limiar de ablação o valor de densidade mínima com que o laser promove ablação. No caso do laser de Er,Cr:YSGG, o limiar de ablação para o tecido ósseo é $5 \mathrm{~J} / \mathrm{cm}^{2}$. ${ }^{37}$

Diversos estudos foram realizados utilizando estes lasers no corte ósseo ${ }^{4,9,34}$ demonstrando que eles são mais eficientes ao remover o tecido que os lasers de $\mathrm{Ho}: Y A G, \mathrm{Nd}: Y A G$, e $\mathrm{CO}_{2}$, uma vez que o fazem de forma mais rápida e com menor dano aos tecido remanescentes ${ }^{4,34}$. Não existe consenso na literatura sobre os efeitos destes lasers na regeneração óssea, uma vez que há estudos que demonstram atraso nos primeiros estágios da regeneração do osso em cortes realizados com laser em comparação com as brocas ${ }^{35,38}$, enquanto outros sugerem não haver diferenças significativas entre os instrumentos ${ }^{39.40}$, e alguns resultados indicam regeneração mais rápida quando os corte foram realizados com laser ${ }^{34}$. As diferenças nos resultados reportados ocorrem devido às densidades de energia utilizadas e também à utilização ou não de água e ar para refrigeração durante a irradiação, o que influencia no aumento da temperatura dos tecidos adjacentes.

Eriksson e colaboradores ${ }^{41}$ demonstrou que se o tecido ósseo sofre danos irreversíveis quando submetido a um aumento de temperatura de $10^{\circ} \mathrm{C}$ por mais de um minuto, entretanto, aumentos de temperaturas maiores com menor duração, ou um menor aumento de temperatura em maior duração podem afetar o tecido. Como pode ser observado na FIG. 6, mesmo um pequeno aumento de temperatura pode afetar a estabilidade térmica dos compostos do osso, o que pode afetar a processo regenerativo. 


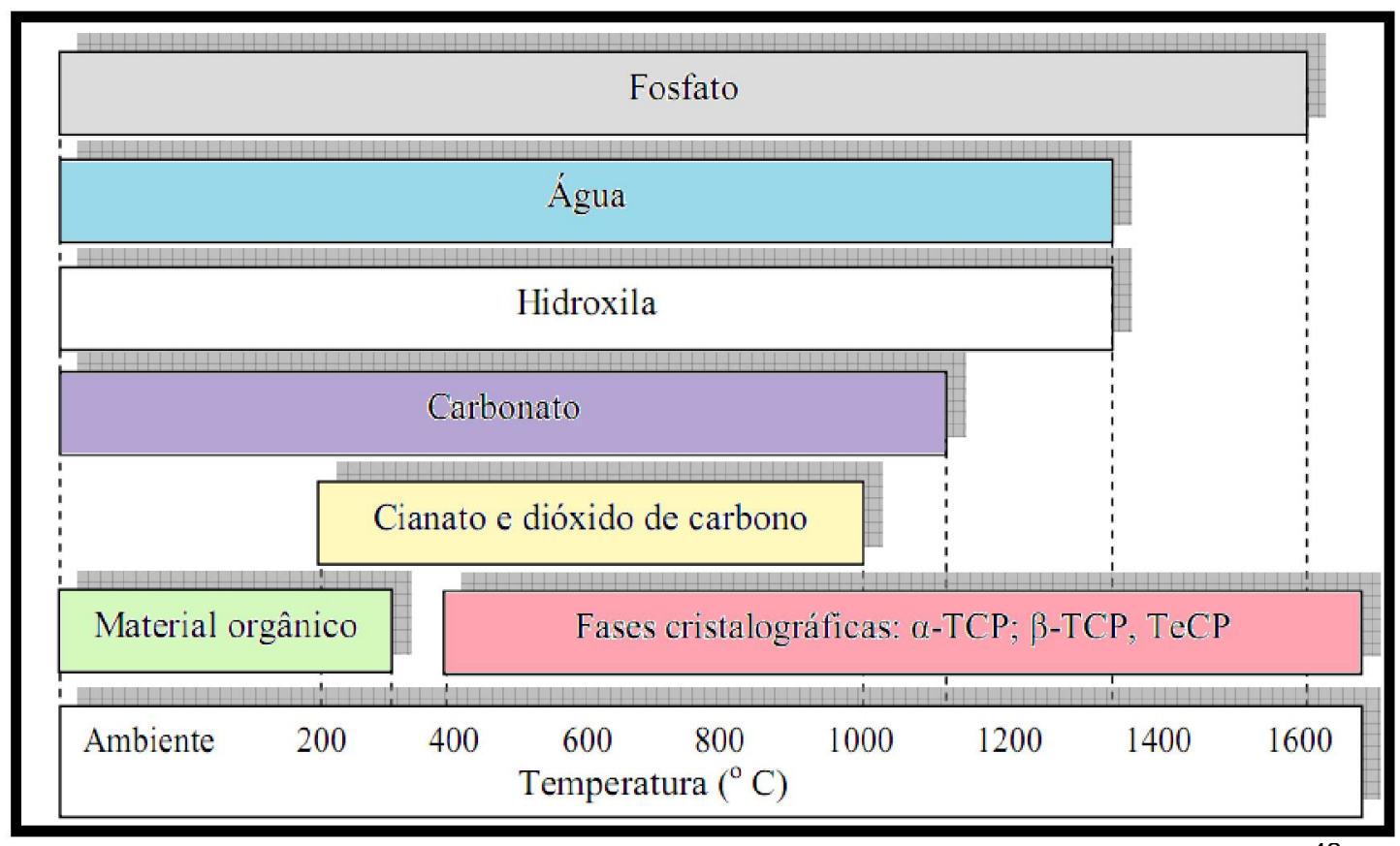

FIGURA 6 - Estabilidade térmica dos principais componentes do osso ${ }^{42}$.

Apesar dos diferentes resultados reportados todos os estudos realizados indicam que os lasers de Er,Cr:YSGG e Er:YAG têm potencial como ferramenta de corte, seja na substituição da broca, ou apenas como uma ferramenta de auxílio para situações específicas, sendo importante o estudo dos efeitos do laser no tecido ósseo para uma melhor compreensão das suas implicações no processo de remoção e regeneração óssea.

\subsection{Espectroscopia no Infravermelho por transformada de Fourier}

\subsubsection{Radiação Eletromagnética}

As ondas eletromagnéticas (radiação eletromagnética) são a combinação de um campo elétrico e um campo magnético que se propagam simultaneamente, oscilando perpendicularmente um ao outro e à direção da propagação de energia (FIG. 7). São classificadas no espectro eletromagnético (FIG. 8) conforme sua energia, frequência ou comprimento de onda ${ }^{43}$. 

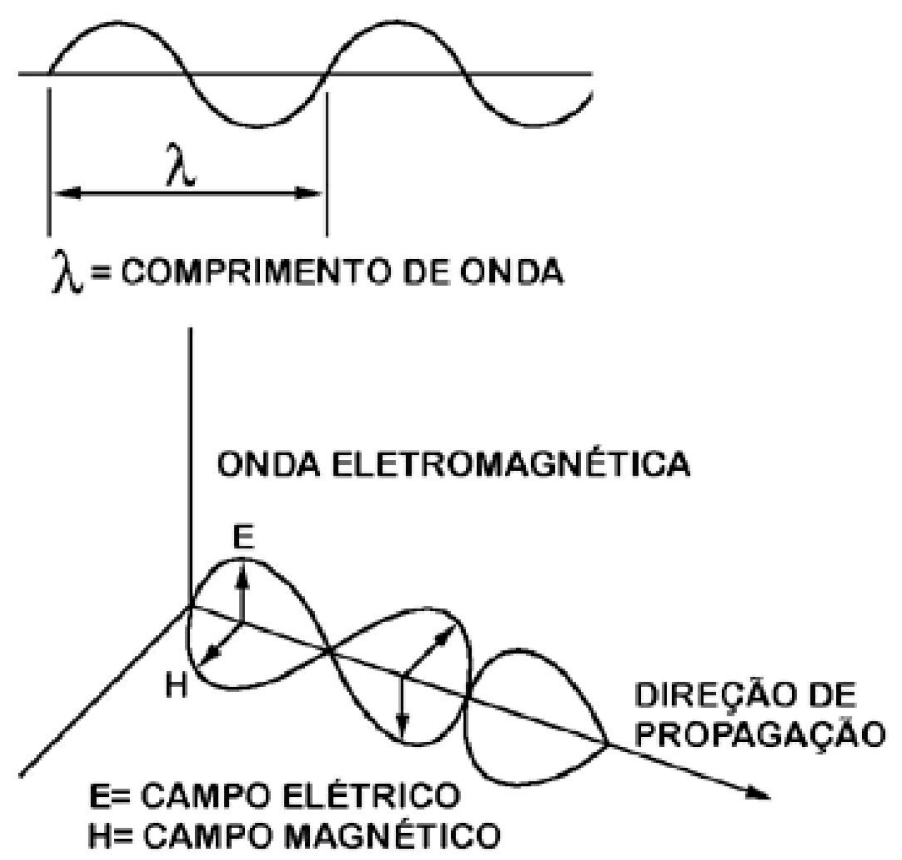

FIGURA 7 - Onda eletromagnética ${ }^{44}$.

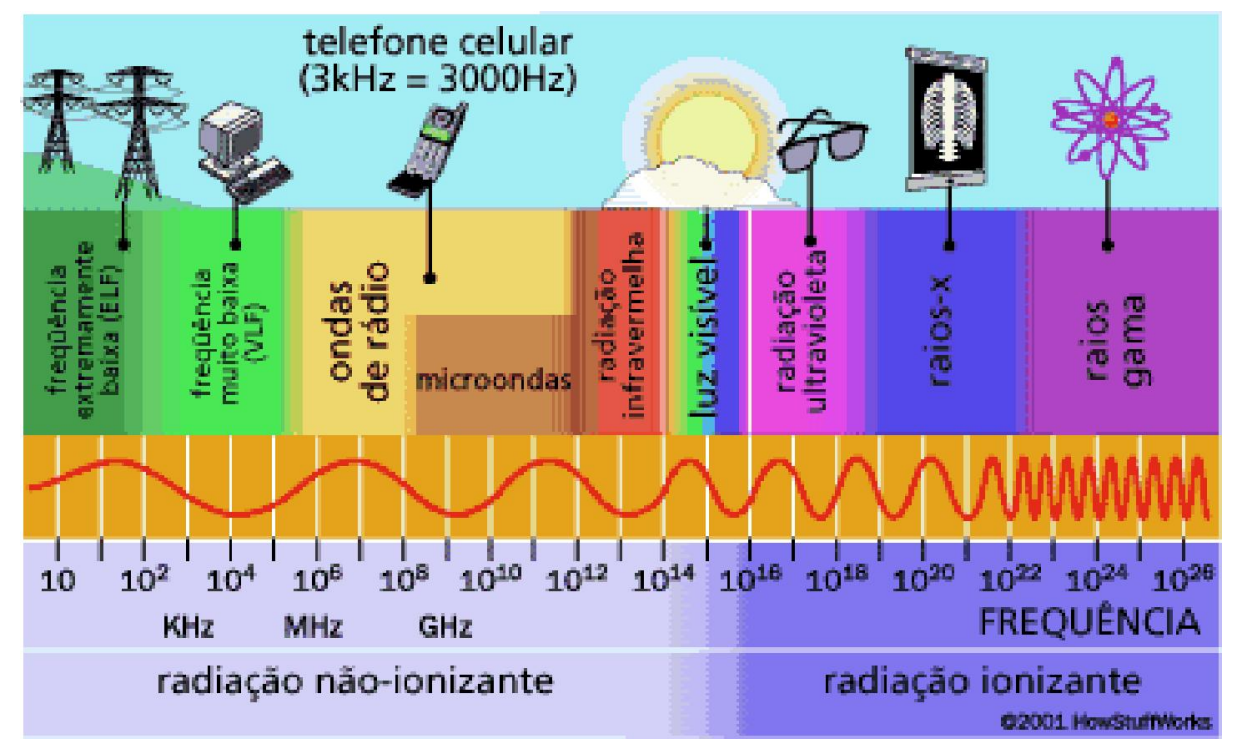

FIGURA 8 - Espectro eletromagnético

A energia de uma onda eletromagnética é proporcional à sua frequência (expressão 1), e inversamente proporcional ao seu comprimento de onda (expressão 2):

$$
f=\frac{E}{h} \quad(1) \quad \lambda=\frac{c}{f}
$$


onde $f$ é a frequência, $E$ a energia e $h$ a constante de Planck, $\lambda$ o comprimento de onda e $c$ a velocidade da luz no vácuo ${ }^{43}$.

A radiação infravermelha, utilizada neste trabalho, localiza-se na região espectral entre a luz visível e as micro-ondas (FIG. 8), compreendendo radiações com número de onda de 12800 a $10 \mathrm{~cm}^{-1}$, aproximadamente, ou comprimento de onda de 0,78 a $1000 \mu \mathrm{m}$. Ela é subdividida em três regiões, conforme apresentado na TAB. 1, sendo a região mais comumente utilizada em análise de compostos orgânicos de 4000 a $670 \mathrm{~cm}^{-1} \cdot{ }^{15}$

TABELA 1 - Subdivisões da região espectral do infravermelho ${ }^{45}$.

\begin{tabular}{c|c|c|c}
\hline & $\begin{array}{c}\text { Número de onda } \\
\left(\mathbf{c m}^{-1} \mathbf{)}\right.\end{array}$ & $\begin{array}{c}\text { Frequência } \\
\mathbf{( H z )}\end{array}$ & $\begin{array}{c}\text { Comprimento } \\
\text { de onda }(\boldsymbol{\mu m})\end{array}$ \\
\hline $\begin{array}{c}\text { Infravermelho } \\
\text { próximo }\end{array}$ & $12800-4000$ & $3,8 \times 10^{14}-1,2 \times 10^{14}$ & $0,78-2,5$ \\
\hline $\begin{array}{c}\text { Infravermelho } \\
\text { médio }\end{array}$ & $4000-200$ & $1,2 \times 10^{14}-6,0 \times 10^{12}$ & $2,5-50$ \\
\hline $\begin{array}{c}\text { Infravermelho } \\
\text { distante }\end{array}$ & $200-10$ & $6,0 \times 10^{12}-3,0 \times 10^{11}$ & $50-1000$ \\
\hline
\end{tabular}

$\mathrm{Na}$ espectroscopia de infravermelho, a característica utilizada para classificar as ondas eletromagnéticas é o número de onda, pois este é diretamente proporcional à sua energia e frequência, além de possuir ordens de grandeza de fácil representação.

Em teoria, ele representa o número de vezes que uma onda atinge a mesma fase em uma determinada distância de propagação (expressão 3). Mas na prática, ele é calculado utilizando-se a expressão (4): 


$$
k=\frac{2 \pi}{\lambda} \quad \text { (3) } \quad k=\frac{1}{\lambda}
$$

onde $k$ é o número de onda, e $\lambda$ é o comprimento de onda.

\subsubsection{Técnicas Espectroscópicas}

Chama-se de espectroscopia qualquer técnica de análise que utiliza a interação da radiação eletromagnética com a matéria para obter informações físicas e químicas sobre o material analisado. As técnicas espectroscópicas são divididas em espectroscopia de emissão e de absorção. Na espectroscopia de emissão, ocorre a excitação dos átomos do alvo do material estudado por meios térmicos e eletrônicos. Quando os átomos decaem de volta ao estado estável, emitem a energia que haviam absorvido em forma de ondas eletromagnéticas, sendo a energia emitida utilizada para a análise do material. A FIG. 9 apresenta um esquema do funcionamento da técnica de espectroscopia por emissão. $\mathrm{Na}$ espectroscopia de absorção, a substância analisada é posicionada entre o detector e uma fonte de energia que emite a radiação eletromagnética com o comprimento de onda desejado. A análise é feita comparando-se a radiação transmitida ou refletida pela amostra, com a radiação da fonte, conforme esquematizado na FIG. $10^{46}$.

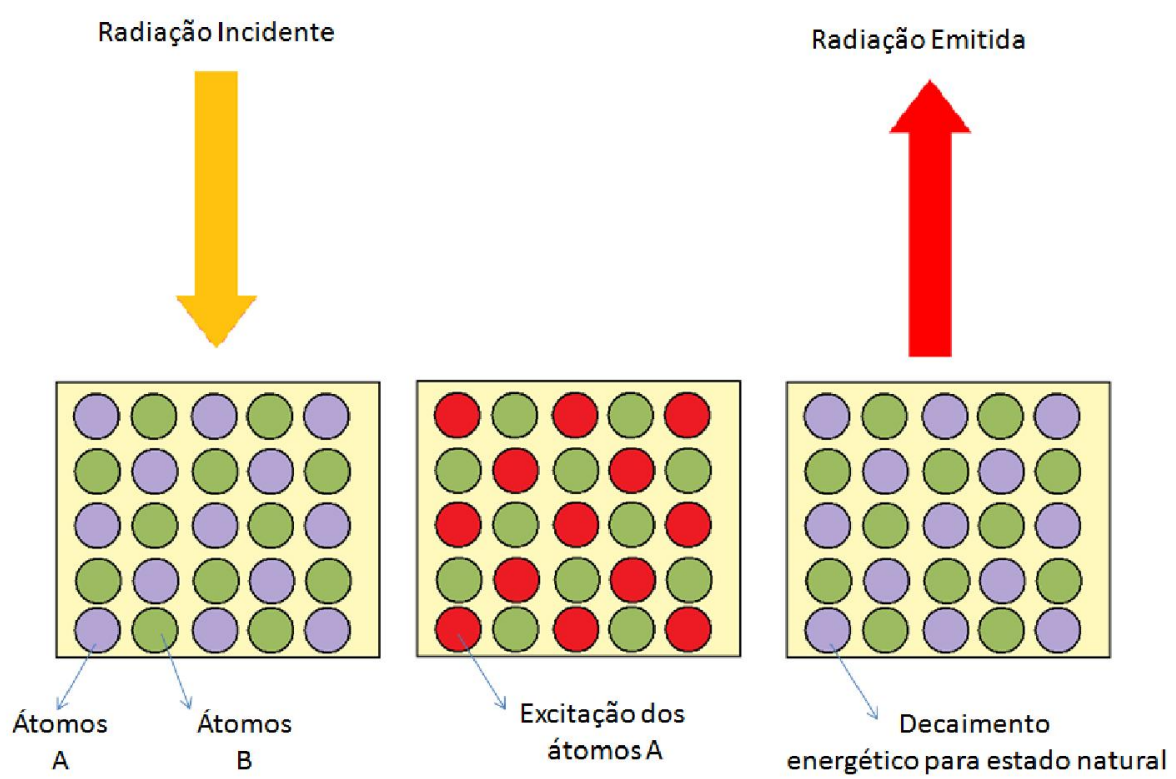


FIGURA 9 - Espectroscopia de emissão

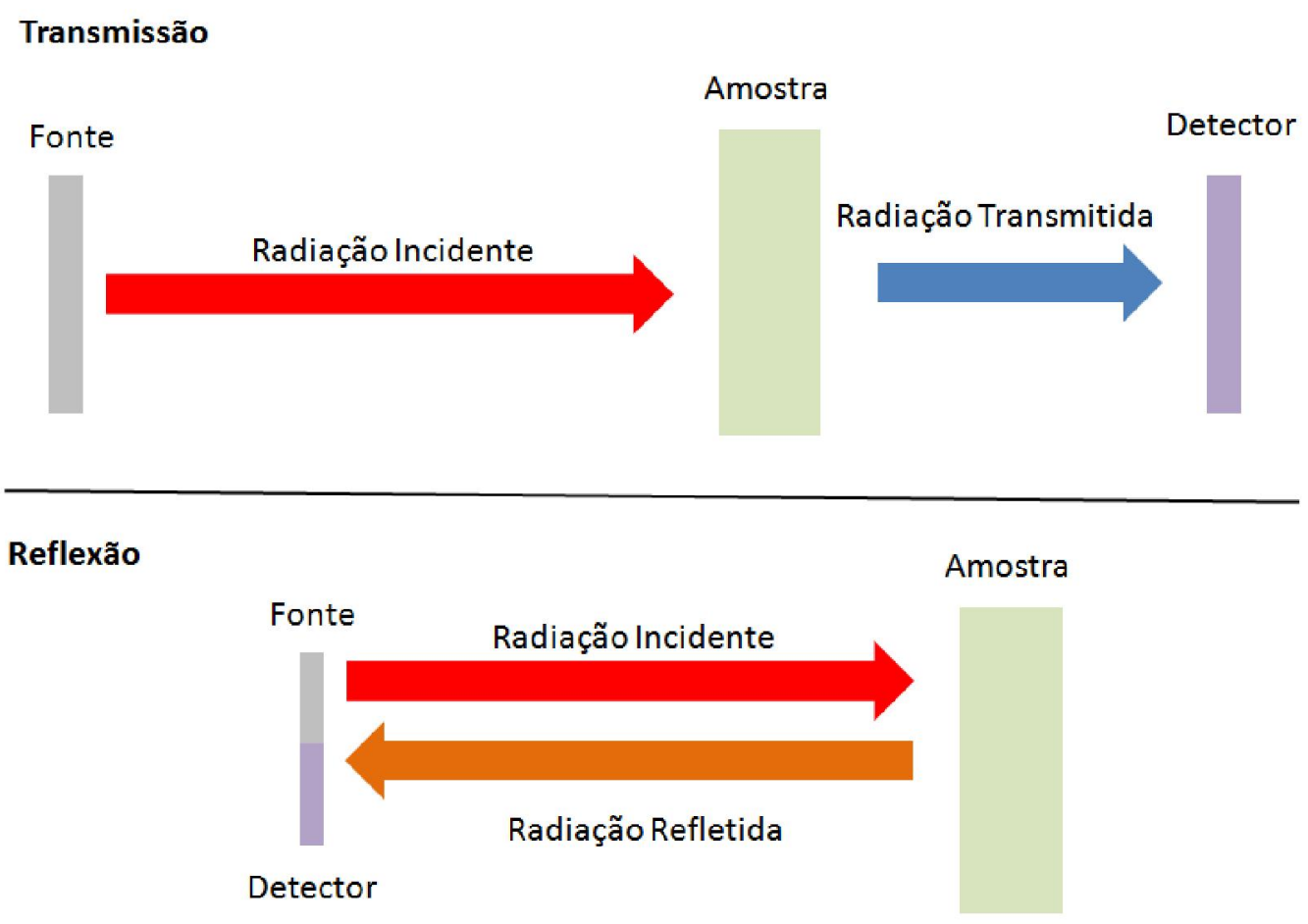

FIGURA 10 - Espectroscopia de absorção por transmissão e reflexão.

A escolha da técnica espectroscópica depende do material ou substância que se deseja analisar, da informação que se pretende obter, e da radiação eletromagnética utilizada. Quando se trata de compostos orgânicos a espectroscopia de absorção da radiação no infravermelho é a mais adequada, pois existe uma ampla gama de compostos que apresentam bandas de absorção $^{45,46}$.

O processo de absorção ocorre quando a frequência da radiação incidente é a mesma que a frequência de vibração molecular. As moléculas e átomos que compõe um material não são estáticos; possuem uma frequência natural de vibração (FIG. 11). Quando a vibração molecular origina uma mudança no momento dipolo da molécula, surge um campo elétrico. Se a radiação eletromagnética tiver a mesma frequência da vibração molecular, o campo elétrico que compõe a radiação incidente interage com o campo elétrico originado pela mudança de momento dipolo, e ocorre uma transferência de energia (absorção) ${ }^{45}$. 


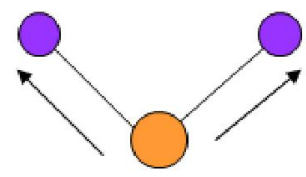

Symmetric stretching (Estiramento Simétrico)

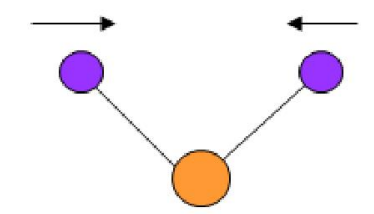

Deformation/Scissoring (Tesoura)

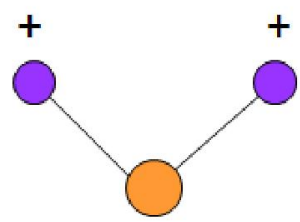

Wagging

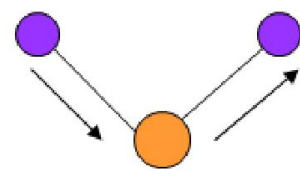

Asymmetric stretching (EstiramentoAssimétrico)

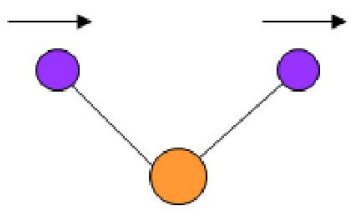

$$
\begin{array}{r}
\text { Rocking } \\
\text { (Balanço) }
\end{array}
$$

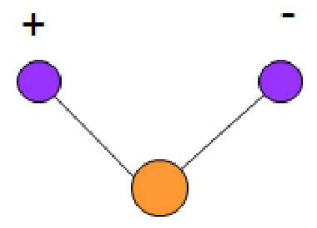

Twisting

(Torção)

FIGURA 11 - Modos de vibração molecular

Pode-se calcular a frequência de vibração de uma molécula utilizando-se a expressão (5):

$$
v=\frac{1}{2 \pi} \sqrt{\frac{k}{\mu}}
$$

onde: $v$ é a frequência vibracional, $k$ a constante de ligação química (uma medida da rigidez), e $\mu$ a massa reduzida, dada por:

$$
\mu=\frac{m_{1} m_{2} \ldots m_{n}}{m_{1}+m_{2}+\ldots+m_{n}}
$$

onde $m_{1}, m_{2}, m_{n}$ são as massas dos $n$ átomos que formam a molécula ${ }^{15}$.

A radiação infravermelha não possui energia suficiente para que sua absorção alterar o nível energético da molécula ${ }^{45}$, e por isso a técnica espectroscópica utilizada é de absorção (FIG. 10), sendo que o sinal analisado 
será o transmitido ou o refletido, a depender do equipamento utilizado e do material analisado.

\subsubsection{ATR - FTIR}

Desde os anos 80, quando a tecnologia permitiu um avanço dos equipamentos de espectroscopia no infravermelho com transformada de Fourier (FTIR), o uso dessa técnica vem crescendo. Em comparação com os demais equipamentos espectroscópicos existentes, os espectrômetros com transformada de Fourier apresentam uma série de vantagens como: melhor relação sinal-ruído, maior velocidade de coleta dos dados, e maior resolução ${ }^{45}$.

Os componentes básicos de um equipamento de espectroscopia FTIR são apresentados na FIG. 12. A radiação proveniente de uma fonte passa por um interferômetro antes de atingir a amostra. A radiação refletida ou transmitida (dependendo do equipamento) atinge o detector. O sinal passa por um amplificador, convertido em sinal analógico, e é enviado para um computador, onde a transformada de Fourier é aplicada ${ }^{47}$.

\section{Fonte Interferômetro Amostra Detector Amplificador Conversor Computador}

FIGURA 12 - Componentes básicos de um equipamento de espectroscopia FTIR

A maioria dos equipamentos FTIR utiliza o interferômetro de Michelson (FIG. 13) ou interferômetros com variações do modelo Michelson. Ele consiste em dois espelhos planos perpendiculares um ao outro, um fixo e outro móvel, e um espelho semi-reflexivo (beamsplitter) posicionado na bissetriz dos espelhos, que permite a passagem apenas de uma parcela do feixe. Uma fonte de radiação emite um feixe colimado de comprimento de onda $\lambda$, ao passar pelo beamsplitter o feixe é $50 \%$ transmitido para um dos espelhos e $50 \%$ refletido para o outro espelho. Os dois espelhos refletem o feixe de volta ao beamsplitter, onde eles são recombinados, e o "novo" feixe incide na amostra. Após passar pela primeira vez no beamsplitter cada parcela do feixe inicial percorre um caminho óptico diferente, visto que a distância do espelho móvel ao beamsplitter varia. Portanto, existe uma 
diferença de fase entre as porções do feixe quando elas se reencontram no beamsplitter. Dependendo desta diferença, a interação entre as parcelas do feixe podem ser construtivas ou destrutivas ${ }^{47}$.

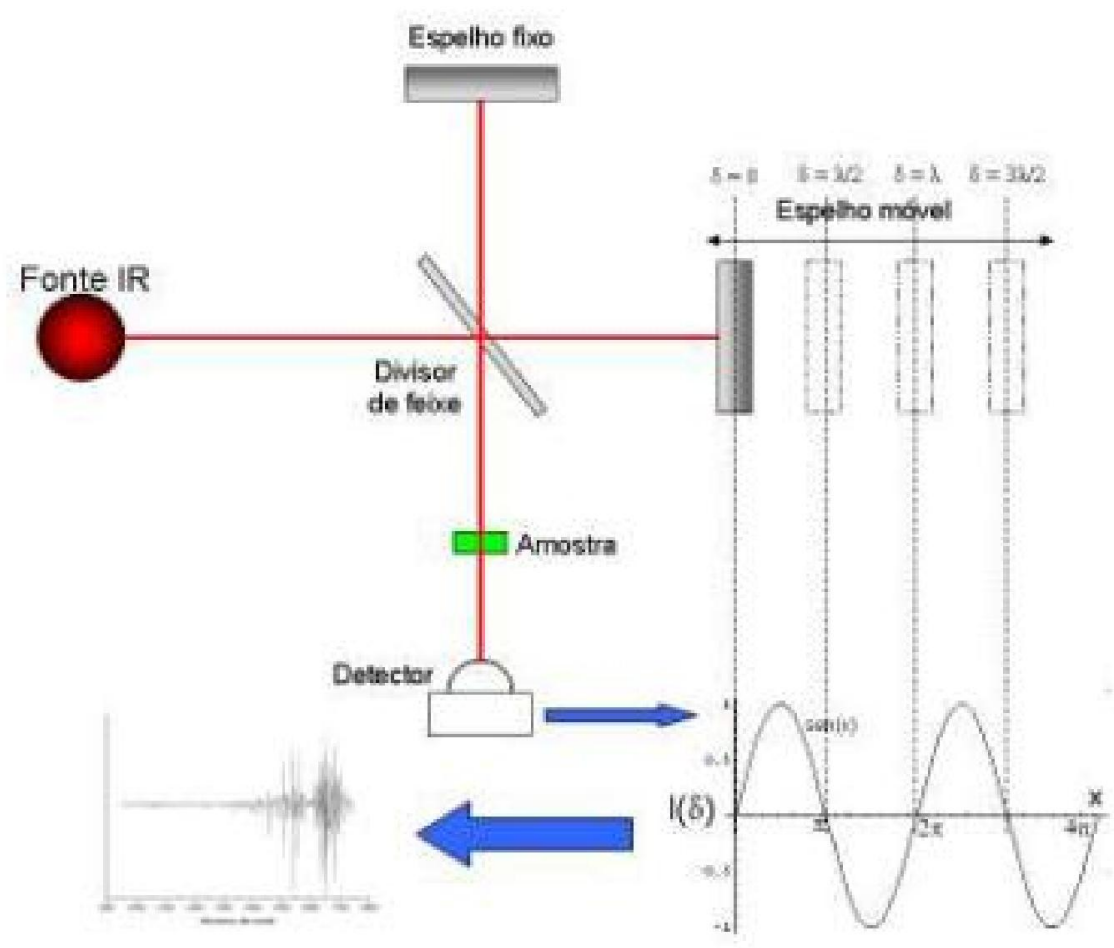

FIGURA 13 - Interferômetro de Michelson ${ }^{48}$

A FIG 13(i) mostra o resultado do interferograma de Michelson para uma fonte monocromática. O irterferograma é um gráfico da intensidade que chega ao detector pela posição do espelho móvel. Quando a posição do espelho é tal que a diferença de fase das parcelas do feixe é $n \lambda$, sendo $n$ um número inteiro, então a interferência da onda é construtiva; se o fator de multiplicação do $\lambda$ não for inteiro a interferência é destrutiva. A FIG 14(ii) apresenta um interferograma no caso de uma fonte de radiação policromática, ou seja, com mais de um comprimento de onda. 

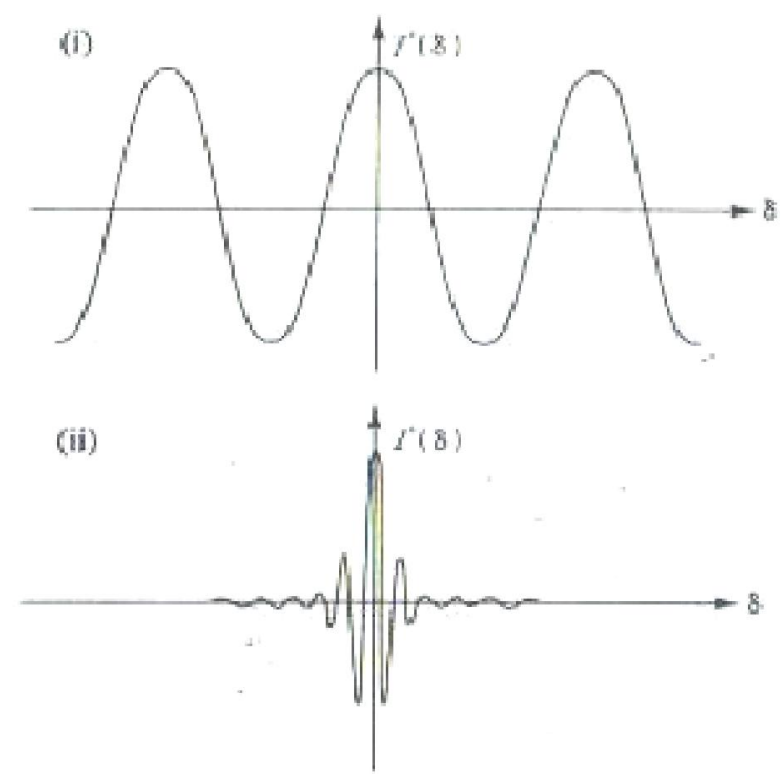

FIGURA 14 - Interferograma: (i) fonte monocromática; (ii) fonte policromática. ${ }^{47}$

Normalmente existem dois interferômetros nos equipamentos: um para formar o feixe que vai incidir na amostra e outro para criar o feixe de referência, com o qual a radiação refletida ou transmitida pela amostra vai ser comparada ${ }^{47}$.

Uma vez obtido o interferograma da amostra, utiliza-se a transformada de Fourier para obter o seu espectro. De forma superficial, pode-se dizer que sabemos como a intensidade do feixe varia com a diferença de caminho óptico (expressão 8). Aplicando-se a transformada de Fourier passamos a conhecer como essa intensidade varia com o número de onda (expressão 9):

$$
\begin{aligned}
& I(\delta)=\int_{0}^{\infty} B(k) \cos (2 \pi k \delta) d k \\
& B(k)=\int_{-\infty}^{+\infty} I(\delta) \cos (2 \pi k \delta) d \delta
\end{aligned}
$$

onde $I(\delta)$ é a equação que descreve a intensidade que incide no detector em função da diferença de caminho óptico $(\delta), k$ o número de onda, $B(k)$ a equação 
que descreve a intensidade que incide no detector em função do número de onda ${ }^{47}$.

A técnica reflexão total atenuada (ATR) possibilita a obtenção de espectros qualitativos e quantitativos de amostras sólidas independente de sua espessura ${ }^{15}$. A técnica consiste na reflexão de um feixe que passa de um meio menos denso para um meio mais denso. Entretanto uma pequena parcela da radiação incidente penetra poucos micrometros no meio, e pode ser absorvida (FIG. 15). Essa radiação que penetra no material é chamada de onda evanescente. O meio onde o feixe se propaga inicialmente é composto por um material de alto índice de refração, pode ser um cristal de diamante, $\mathrm{ZnSe}$ ou Ge. A proporção de feixe refletido varia com o ângulo de incidência, havendo um ângulo critico onde a reflexão é total, que depende do elemento de reflexão (o cristal). Com a absorção da radiação que penetrou na amostra o feixe refletido tem sua intensidade atenuada, e assim consegue se identificar as bandas de absorção ${ }^{15,45,47}$.

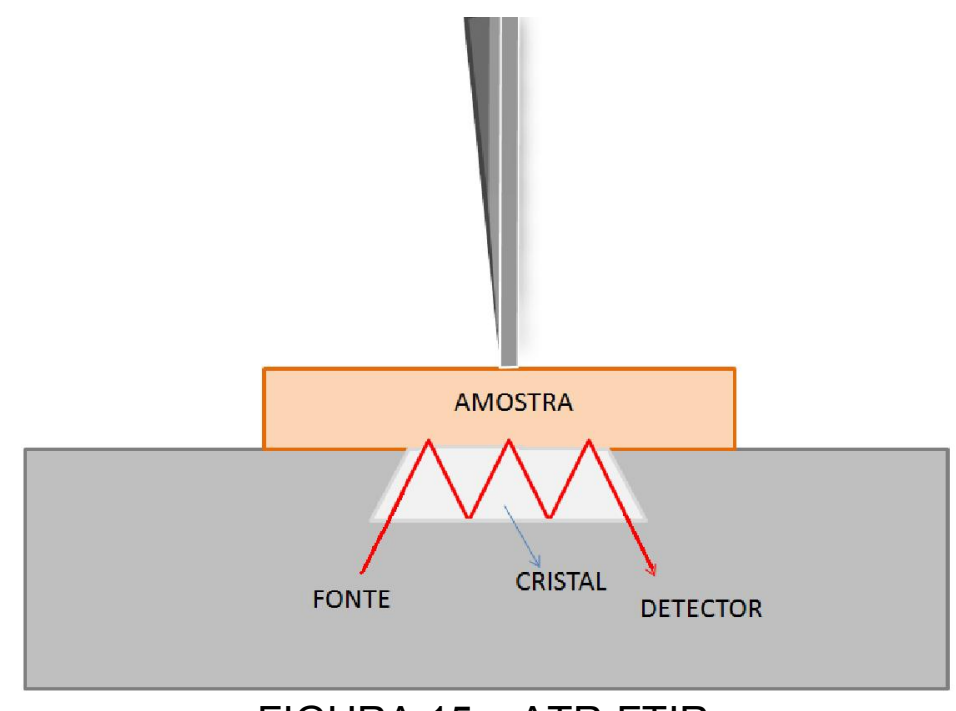

FIGURA 15 - ATR-FTIR

A profundidade da penetração depende do comprimento de onda do feixe $(\lambda)$, do ângulo de incidência deste com a amostra $(\theta)$, e do índice de refração do cristal do equipamento $\left(n_{2}\right)$ e do material analisado $\left(n_{1}\right)$, que se relacionam por :

$$
d_{p}=\frac{\lambda / n_{1}}{2 \pi\left[\sin \theta-\left(n_{1} / n_{2}\right)^{2}\right]^{\frac{1}{2}}}
$$


onde $d_{p}$ é a profundidade de penetração ${ }^{47}$. A FIG. 16 apresenta o gráfico da profundidade de penetração do feixe do ATR-FTIR utilizado em amostras de osso. Considerou-se um diamante de índice de refração de $2,42^{49}$, e a amostra de osso com índice de refração de $1,55^{49}$. O ângulo de incidência foi considerado como $45^{\circ}$; e o comprimento de onda foi variado de acordo com os valores utilizados neste estudo.

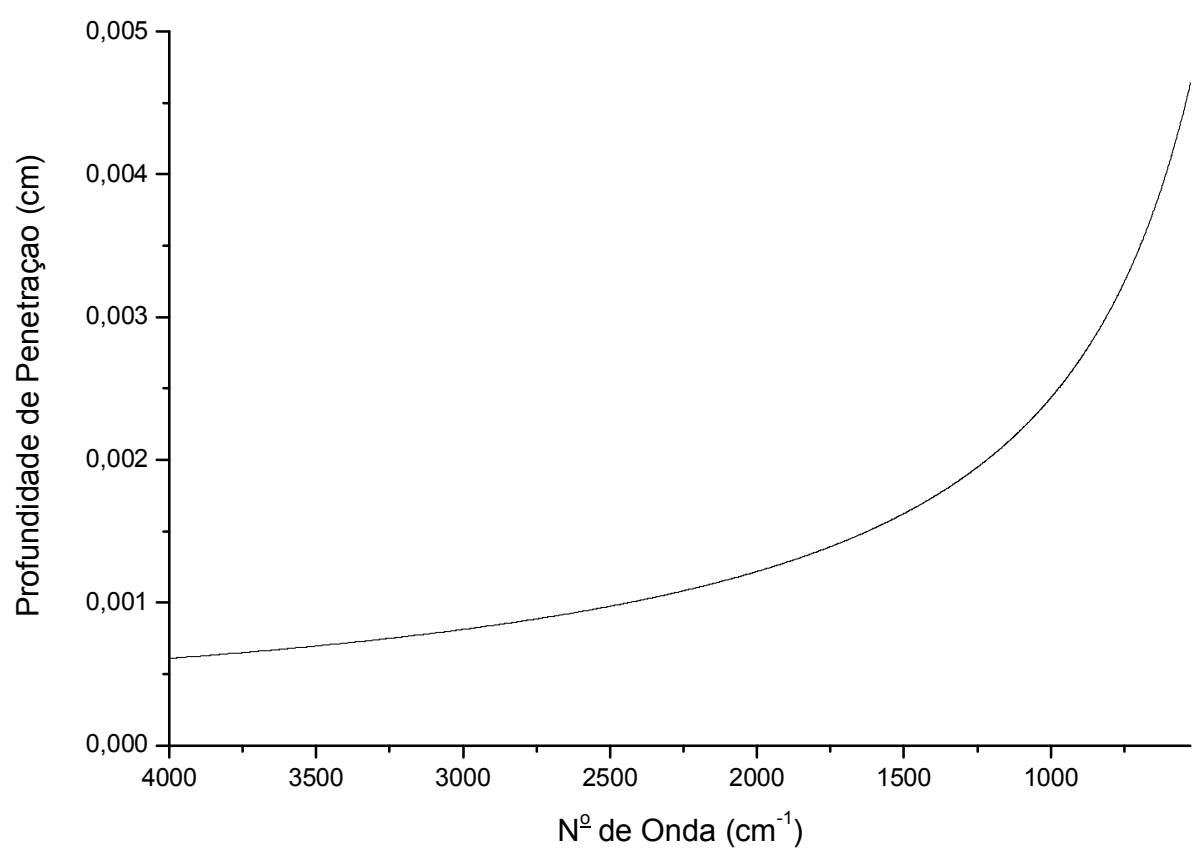

FIGURA 16 - Profundidade de penetração do feixe do ATR-FTIR em amostras de osso no intervalo de número de onda estudado.

\subsection{Espectroscopia FTIR na análise de tecidos biológicos mineralizados}

As possibilidades de uso da espectroscopia FTIR são vastas, sendo utilizada: no estudo das propriedades químicas de diversos materiais ${ }^{50}$, no diagnóstico de câncer e outras patologias, no combate ao narcotráfico ${ }^{51}$, e na otimização do processo de fabricações de alimentos ${ }^{52}$. Nos tecidos mineralizados, o efeito da irradiação com diferentes densidades de energia foi estudado para o esmalte dental e dentina ${ }^{53,16}$, visando a utilização do laser na prevenção à carie. Também foram realizados estudos para verificar as mudanças químicas e 
estruturais que o aumento de temperatura provoca em hidroxiapatita sintética e no esmalte ${ }^{54,42}$.

Para o tecido ósseo, foram realizados estudos na diferenciação de tecidos saudáveis e cancerígenos, na análise das modificações causadas com o envelhecimento do osso $^{21}$, no estudo da osteoporose ${ }^{19}$, e também na caracterização de tecido ósseo irradiado. Nesses últimos, foi possível observar a perda de compostos orgânicos ${ }^{14}$. Entretanto, não foi estudada a irradiação com diferentes densidades de energia, como proposto neste trabalho.

A utilização da espectroscopia FTIR para verificar as alterações químicas e estruturais promovidas por irradiação laser em diferentes densidades de energia no esmalte e dentina mostrou-se capaz de detectar uma diminuição dos compostos orgânicos com o aumento de densidade de energia ${ }^{53}$. Estudos utilizando a técnica na análise de esmalte dental após aquecimento em forno mostram resultados semelhantes ${ }^{13}$; um indicativo de que as alterações causadas na irradiação são devido ao aumento de temperatura sofrido pela amostra ${ }^{42}$.

\subsubsection{Bandas de Absorção}

Um espectro obtido por espectroscopia ATR-FTIR é apresentado na FIG.17. Na TAB. 2 a TAB. 5 são apresentadas as bandas vibracionais na região do infravermelho para os componentes do osso. 


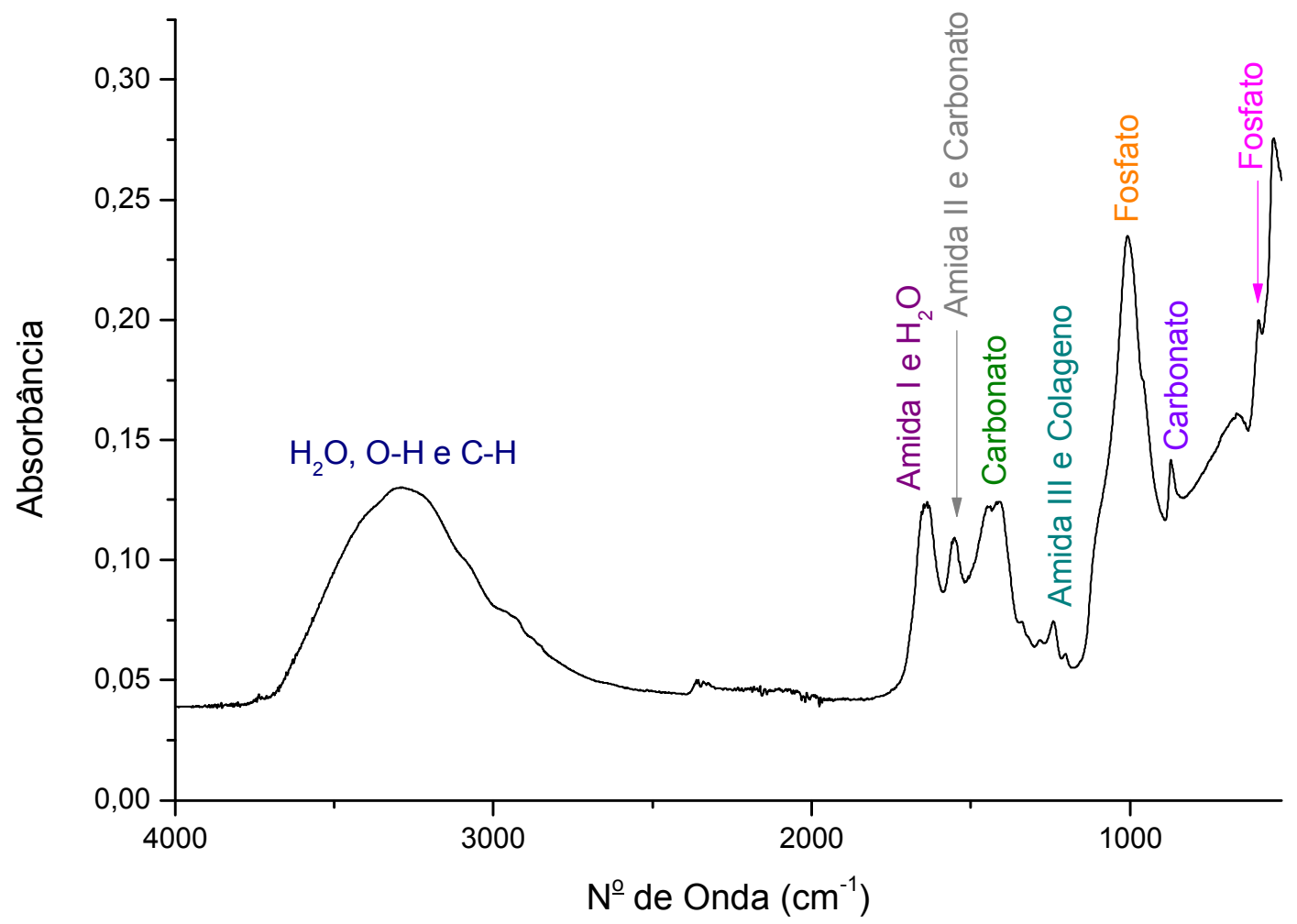

FIGURA 17 - Espectro de osso não irradiado obtido em um equipamento ATRFTIR 
TABELA 2 - Bandas de absorção associadas ao fosfato $\left(\mathrm{PO}_{4}{ }^{3-}\right)$ presente em esmalte, dentina e osso ${ }^{42,54,55}$.

\begin{tabular}{c|c|c|c}
\hline \multirow{2}{*}{ Vibração } & \multicolumn{3}{|c}{$\begin{array}{c}\text { Frequência de vibração } \\
\text { aproximada }\left(\mathbf{c m}^{-1}\right)\end{array}$} \\
\cline { 2 - 4 } & Esmalte & Dentina & Osso \\
\hline $\begin{array}{c}\text { Deformação } \\
\text { angular } \\
\text { simétrica no } \\
\text { plano }\left(v_{2}\right)\end{array}$ & 471 & 471 & 470 \\
\hline Deformação & 561 & 563 & \\
angular & 602 & 603 & 600 \\
assimétrica no & 582 & 755 & 560 \\
plano $\left(v_{4}\right)$ & 620 & 606 & 575 \\
\hline & 559 & 1020 \\
Estiramento & 1028 & $1280-950$ & 1100 \\
assimétrico $\left(v_{3}\right)$ & 1008 & & 1125 \\
& & & 1145 \\
\hline$v_{1}$ & $950-1000$ & $470 / 467$ & 960 \\
\hline
\end{tabular}


TABELA 3 - Bandas de absorção associadas ao carbonato $\left(\mathrm{CO}_{3}{ }^{2-}\right)$ presente em esmalte, dentina e osso ${ }^{21,53,54,56}$.

\begin{tabular}{c|c|c|c}
\hline \multirow{2}{*}{ Vibração } & \multicolumn{3}{|c}{$\begin{array}{c}\text { Frequência de vibração } \\
\text { aproximada }\left(\mathbf{c m}^{-1}\right)\end{array}$} \\
\cline { 2 - 4 } & Esmalte & Dentina & Osso \\
\hline $\begin{array}{c}\text { Deformação } \\
\text { angular }\end{array}$ & & & $868 / 866$ \\
assimétrica no & $873 / 880$ & 872 & 871 \\
plano $\left(v_{2}\right)$ & & & $877 / 879$ \\
\hline \multirow{2}{*}{$\begin{array}{c}\text { Estiramento } \\
\text { assimétrico }\left(v_{3}\right)\end{array}$} & 1460 & 1410 & 1417 \\
& 1543 & 1547 & 1441 \\
& 1460 & 1540 & 1460 \\
\end{tabular}


TABELA 4 - Bandas de absorção associadas na região espectral de 4000 - 2500 $\mathrm{cm}^{-1}$ em esmalte, dentina e osso $\mathrm{o}^{2,42,54,57,58}$

\begin{tabular}{|c|c|c|c|c|}
\hline \multirow[t]{2}{*}{ Composto } & \multirow[t]{2}{*}{ Vibração } & \multicolumn{3}{|c|}{$\begin{array}{c}\text { Frequência de vibração } \\
\text { aproximada }\left(\mathrm{cm}^{-1}\right)\end{array}$} \\
\hline & & Esmalte & Dentina & Osso \\
\hline $\mathrm{OH}$ estrutural & libração & 635 & 749 & - \\
\hline $\mathrm{H}_{2} \mathrm{O}$ adsorvida & $\begin{array}{c}\text { Deformação } \\
\text { angular } \\
\text { assimétrica fora } \\
\text { do plano }\left(v_{2}\right)\end{array}$ & 1638 & 1648 & - \\
\hline $\mathrm{H}_{2} \mathrm{O}$ adsorvida & $\begin{array}{l}\text { Estiramento } \\
\text { simétrico }\end{array}$ & 3448 & & - \\
\hline $\mathrm{OH}$ estrutural & Estiramento & 3569 & 3580 & - \\
\hline $\mathrm{H}_{2} \mathrm{O}$ ou Amida $\mathrm{A}$ & $v_{1}+2 v_{2}$ & - & 3318 & - \\
\hline $\mathrm{H}_{2} \mathrm{O}$ & $v_{1}+2 v_{2}$ & - & 3200 & - \\
\hline $\mathrm{H}_{2} \mathrm{O}$ & $v_{3}$ & - & 3410 & - \\
\hline Amida B & & - & 3066 & - \\
\hline $\mathrm{C}-\mathrm{H}$ & estiramento & $\begin{array}{l}- \\
- \\
-\end{array}$ & $\begin{array}{l}2961 \\
2931 \\
2875\end{array}$ & $\begin{array}{l}- \\
- \\
-\end{array}$ \\
\hline Grupo OH & & - & - & $\begin{array}{c}3600-2400 \\
3500-3300 \\
3500-2500 \\
1620\end{array}$ \\
\hline
\end{tabular}


TABELA 5 - Bandas de absorção associadas na região espectral de 1750 - 1180 $\mathrm{cm}^{-1}$ em esmalte, dentina e osso ${ }^{2,42,54,57,58}$

\begin{tabular}{|c|c|c|c|c|}
\hline \multirow[t]{2}{*}{ Composto } & \multirow[t]{2}{*}{ Vibração } & \multicolumn{3}{|c|}{$\begin{array}{c}\text { Frequência de vibração } \\
\text { aproximada }\left(\mathrm{cm}^{-1}\right)\end{array}$} \\
\hline & & Esmalte & Dentina & Osso \\
\hline Amida III & & 1236 & 1224 & $\begin{array}{l}1320-1190 \\
1300-1200\end{array}$ \\
\hline $\begin{array}{l}\text { Carbonato+Amida II } \\
\qquad \begin{array}{c}\mathrm{N}-\mathrm{H} \\
\mathrm{C}-\mathrm{N}\end{array}\end{array}$ & & $\begin{array}{l}1395 \\
1443 \\
1534\end{array}$ & $\begin{array}{l}1393 \\
1442 \\
1540\end{array}$ & $\begin{array}{c}1550 \\
1560-1510 \\
1580-1480\end{array}$ \\
\hline $\begin{array}{c}\text { Água+Amida I } \\
\qquad \mathrm{C}=\mathrm{O}\end{array}$ & & $\begin{array}{l}1634 \\
1650\end{array}$ & $1700-1550$ & $\begin{array}{c}1650 \\
1680-1620 \\
1680-1600\end{array}$ \\
\hline $\begin{array}{l}\text { Estrutura do } \\
\text { Colágeno }\end{array}$ & & - & $\begin{array}{l}1338 / 1335 \\
1288 / 1281 \\
1204 / 1201\end{array}$ & $\begin{array}{c}1334 / 1342 \\
1276 \\
1204\end{array}$ \\
\hline $\mathrm{CH}_{3}$ & abano & - & 1315 & - \\
\hline $\begin{array}{c}\text { CONH (amida III) } \\
\text { CN } \\
\mathrm{NH}\end{array}$ & $\begin{array}{c}\text { - } \\
\text { Estiramento } \\
\text { Deformação }\end{array}$ & - & $1245 / 1234(\mathrm{~L})$ & $\begin{array}{c}1238 / 1233 \\
1240\end{array}$ \\
\hline
\end{tabular}




\section{MATERIAL E MÉTODOS}

\subsection{Preparação das amostras}

Este trabalho foi aprovado pelo comitê de ética em pesquisa animal do IPEN - CNEN/SP ( $n^{\circ}$. 6/CEPA-IPEN/SP).

As amostras foram obtidas da tíbia de dois coelhos adultos, machos, da raça New Zealand, adquiridos do Biotério da Faculdade de Medicina da USP. Após o sacrifício (utilizando quetamina e xilazina em dose letais), os ossos foram seccionados ao meio, a medula óssea retirada, e as partes cortadas em pedaços de aproximadamente $10 \times 15 \mathrm{~mm}$ utilizando-se o motor odontológico de alta rotação com uma ponta diamantada (endo $Z-21 \mathrm{~mm}$ ).

Cada pedaço de osso obtido foi lixado utilizando lixas d'águas de numeração 1800, 2500, 4000, respectivamente, tomando-se o cuidado de movimenta-los em movimentos formando um oito, para não criar marcas. Ambos os lados foram lixados, uma vez que a região do periósteo (região externa do osso) é convexa e a região do endósteo, (vizinha ao canal medular) é côncava e bastante irregular. Portanto, no processo de lixamento, as amostras foram planificadas até atingir a espessura de aproximadamente $100 \mu \mathrm{m}$, espessura esta determina em um dos estudos pilotos por permitir um maior contato da amostra com o cristal do ATR, devido a flexibilidade de amostras com esta espessura.

O processo de lixamento diminui as dimensões das amostras devido ao desgaste das extremidades, sendo que ao final do processo, as amostras tinham a dimensão de $8 \times 5 \mathrm{~mm}$, com espessura de $100 \mu \mathrm{m}$ e tolerância de $10 \%$. As amostras foram mantidas em ambiente refrigerado em meio úmido para não perderem suas características naturais. A FIG. 18 ilustra o processo de preparação de amostras. 


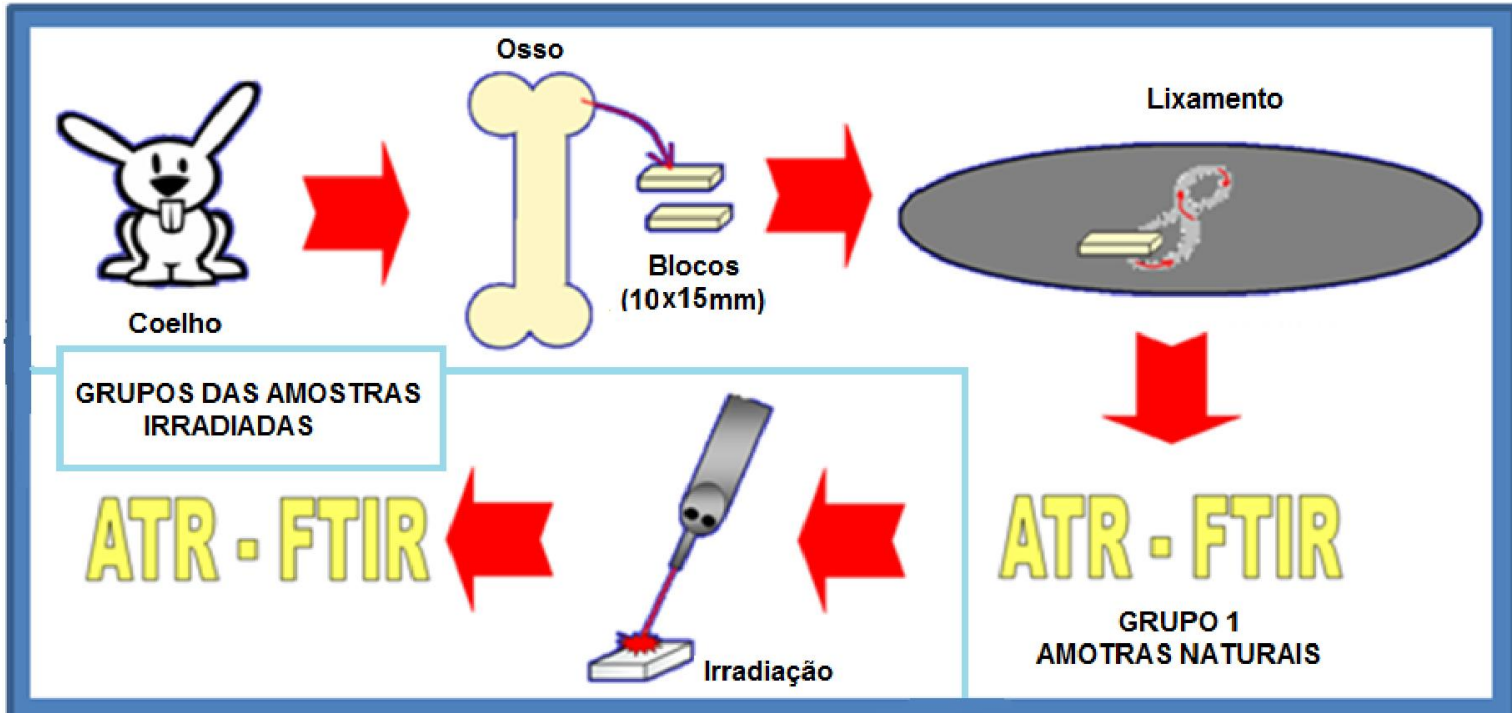

FIGURA 18 - Preparação das amostras.

No total foram utilizadas 19 amostras, divididas conforme os tipos de estudos que foram realizados (TAB. 6).

TABELA 6 - Divisão conforme o estudo realizado das 22 amostras.

\begin{tabular}{c|c}
\hline No de amostras & Estudo realizado \\
\hline 1 & $\begin{array}{c}\text { Determinação das melhores } \\
\text { condições do espectrômetro ATR-FTIR }\end{array}$ \\
\hline 3 & Estudo do osso não irradiado \\
\hline 15 & Estudo da irradiação com diferentes \\
& densidades de energia \\
\hline
\end{tabular}

\subsection{ATR-FTIR}

O espectrômetro utilizado foi um acessório de Reflexão Total Atenuada ATR (Smart Orbit, Thermo, EUA) acoplado a um espectrômetro no infravermelho por transformada de Fourier - FTIR (Nicolet 6700, Thermo Inc., EUA), ambos apresentados na FIG. 19. 


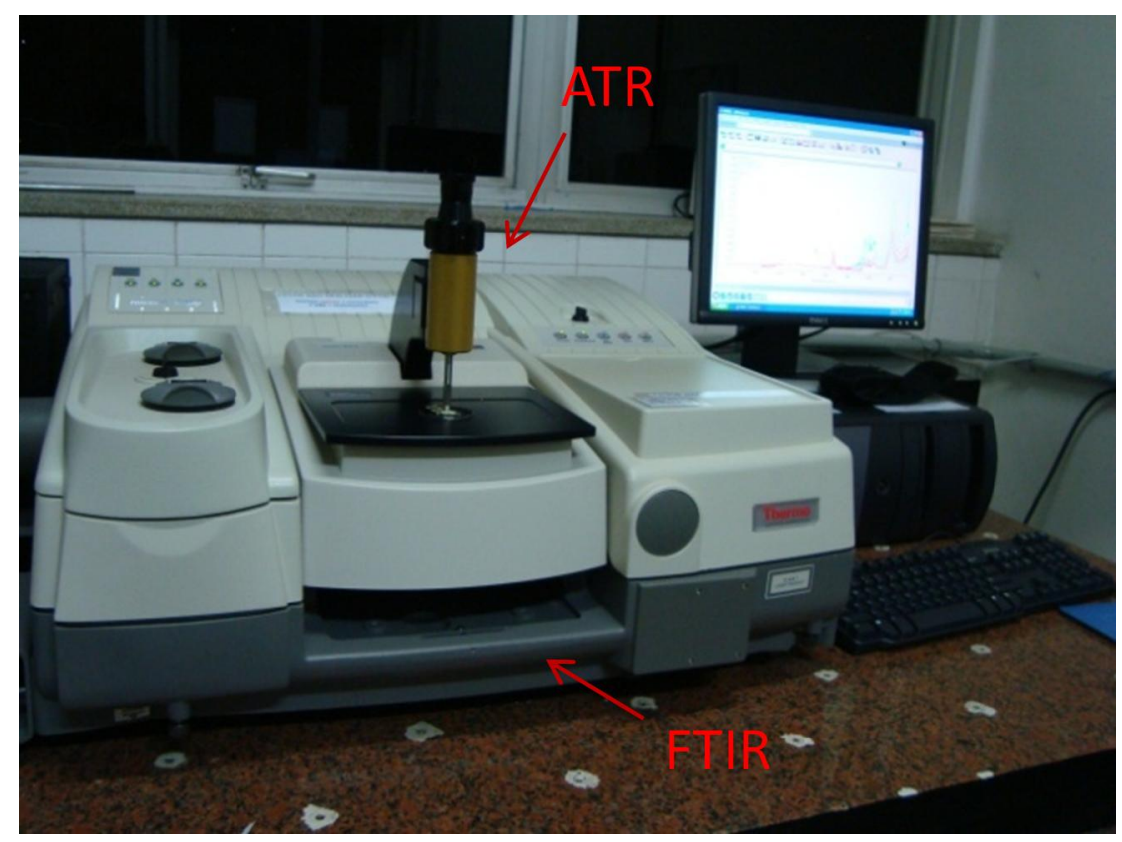

FIGURA 19 - ATR-FTIR

O equipamento trabalha em ambiente de temperatura e umidade controladas em $17{ }^{\circ} \mathrm{C}$ e $40 \%$, respectivamente, para evitar que estes fatores influenciem na obtenção dos espectros.

O ATR utilizado tem como elemento de reflexão interna um cristal de diamante com índice de refração de 2,40 , sendo $38,8^{\circ}$ menor ângulo permitido para a incidência do feixe.

O espectrômetro utilizado permite a caracterização de vários tipos de materiais em diferentes estados. Para a otimização dos espectros das amostras estudadas foram definidos os parâmetros do equipamento, como tipo de detector, resolução e número de varreduras.

O software utilizado na aquisição dos espectros foi o software OMINIC. Os espectros foram salvos em formato CSV e analisados no software Origin 8.0 (Origin ${ }^{\circledR}$, Northampton, MA, USA). 


\subsection{Determinação dos parâmetros do ATR-FTIR}

Antes da análise das amostras não irradiadas (controle) e irradiadas com diferentes densidades de energia, uma amostra de osso não irradiado foi utilizada para a determinação dos melhores parâmetros do equipamento para o tipo de análise realizada, descritos a seguir.

\subsubsection{Detector e Beamsplitter}

Os primeiros parâmetros a serem definidos são o detector e o beamsplitter que serão utilizados. Os fatores que se deve levar em consideração para a escolha são: a compatibilidade entre os sistemas e a faixa espectral de interesse. A compatibilidade se dá quando o sinal do detector é intenso o suficiente para permitir que o beamspliter seja alinhado.

O manual do espectrômetro Nicolet 6700 apresenta uma tabela sobre a compatibilidade dos diferentes detectores e beamsplitters e uma tabela com as faixas espectrais compatíveis com a combinação dos equipamentos.

A cominação beamsplitter XT-KBr e detector DTGS TEC permite a realização de análises na faixa espectral de $11000-375 \mathrm{~cm}^{-1}$, dependendo da fonte utilizada. Como a faixa espectral de interesse é $4500-525 \mathrm{~cm}^{-1}$, ou seja, na região do infravermelho médio, optou-se por utilizar essa combinação, indicada como a melhor para a análise na faixa espectral de interesse.

\subsubsection{Abertura}

O parâmetro 'abertura', que o equipamento permite modificar, refere-se ao diâmetro da abertura por onde passa o feixe laser que atinge a amostra e é uma forma de controlar a intensidade deste feixe. Em geral quanto maior a abertura, melhor a relação sinal ruído, sendo que uma abertura menor melhora a acurácia e estabilidade, sendo normalmente utilizada para experimentos que precisam de alta resolução. 
Os detectores do tipo DTGS, como utilizado neste experimento, são capazes de suportar altas energias e por isso é possível utilizar uma grande abertura. O tamanho da abertura no equipamento utilizado pode variar de 0 a 150 , sendo este um parâmetro de controle, sendo que o tamanho de abertura recomendado pelo fabricante quanto se utiliza detectores do tipo DTGS é 100. Os espectros obtidos com a resolução recomendada possuem a qualidade de sinal suficiente para a identificação das bandas.

\subsubsection{Resolução}

A resolução do equipamento determina quão próximos dois picos podem estar entre si e ainda assim serem identificados como dois picos independentes. Quanto menor o valor da resolução, melhor definida é a posição dos picos.

Assim como o número de varreduras e a velocidade do espelho, a resolução afeta o tempo de coleta do espectro, sendo recomendado aumentar a resolução o suficiente para diferenciar os picos de interesse, uma vez que aumentar a resolução mais que o necessário não promove nenhuma informação adicional e pode aumentar o ruído do espectro.

Normalmente, para amostras liquidas e sólidas utilizam-se resoluções de número de onda de $8 \mathrm{~cm}^{-1}$ a $4 \mathrm{~cm}^{-1}$, e para amostras gasosas, resoluções menores que $2 \mathrm{~cm}^{-1}$. O background e o espectro das amostras devem ser sempre coletados utilizando-se a mesma resolução, sendo o background o espectro de absorção do ambiente.

Para determinar a melhor resolução para amostras de tecido mineralizados com aproximadamente $100 \mu \mathrm{m}$ de espessura, foram realizadas seis medidas independentes de uma mesma amostra de osso de tíbia, sendo os espectros obtidos variando-se a resolução e mantendo-se os demais parâmetros constantes, a saber: 80 varreduras e velocidade do espelho de $0,6329 \mathrm{~cm} / \mathrm{s}$. 
As resoluções testadas são apresentadas na TAB. 7. Para que a posição analisada da amostra não afetasse o espectro, os valores de resolução foram comparados dois a dois, pois o equipamento permite retirar o background antes e depois do espectro da amostra. Desta forma, no primeiro valor de resolução estudado, o background foi obtido antes do espectro da amostra, e no segundo valor, o background foi obtido depois. Assim os dois espectros foram obtidos sem a amostra ser movida, garantindo a análise da mesma região para os dois valores de resolução. Portanto, na TAB. 7 as medidas 1 e 2 são referentes à uma mesma região da amostra, assim como as medidas 3 e 4 , e as medidas 5 e 6 . As diferentes cores das linhas da tabela representam diferentes regiões analisadas em uma mesma amostra.

TABELA 7 - Parâmetros do FTIR utilizado na determinação da resolução. As diferentes cores das linhas da tabela representam diferentes regiões analisadas em uma mesma amostra.

\begin{tabular}{c|c}
\hline Medidas & Resolução $\left(\mathbf{c m}^{-1}\right)$ \\
\hline 1 & 8 \\
\hline 2 & 6 \\
\hline 3 & 6 \\
\hline 4 & 4 \\
\hline 5 & 4 \\
\hline 6 & $2^{*}$ \\
\hline
\end{tabular}

* a abertura teve que ser diminuída para 61, para restringir o feixe e não haver risco de distorcer as bandas.

Os espectros obtidos foram sobrepostos para comparação, e assim foi determinada qual resolução apresentava melhor qualidade para as amostras de osso. 


\subsubsection{Número de varreduras}

O número de varreduras, como o próprio nome diz, determina quantas varreduras serão realizadas durante a aquisição do background e do espectro da amostra. Quando mais de uma varredura é realizada, o sistema calcula a média para o espectro final. Normalmente, aumentando-se o número de varreduras diminui-se o ruído, entretanto aumenta-se o tempo de aquisição de dados.

Como realizado na determinação da melhor resolução, foram realizadas seis medidas de uma mesma amostra variando-se o número de varreduras conforme apresentado na TAB. 8 e mantendo-se os demais parâmetros constantes, a saber: resolução $4 \mathrm{~cm}^{-1}$ e velocidade do espelho de $0,6329 \mathrm{~cm} / \mathrm{s}$. Novamente, para que as diferenças das regiões analisadas na amostra não afetassem os resultados, uma mesma região da amostra foi analisada com diferentes números de varreduras, conforme procedimento explicado na determinação da resolução (seção 4.3.3). As diferentes cores das linhas da tabela representam diferentes regiões analisadas em uma mesma amostra.

TABELA 8 - Parâmetros do FTIR utilizado na otimização do número de varreduras. As diferentes cores das linhas da tabela representam diferentes regiões analisadas em uma mesma amostra.

\begin{tabular}{c|c}
\hline Medidas & Número de varreduras \\
\hline 1 & 20 \\
\hline 2 & 40 \\
\hline 3 & 40 \\
\hline 4 & 80 \\
\hline 5 & 80 \\
\hline 6 & 120 \\
\hline
\end{tabular}


Para cada espectro obtido foi calculado individualmente o RMS (Root Mean Square ou raiz quadrática média) do ruído, e a distância pico a pico utilizando-se o software de aquisição dos espectros OMINIC.

O RMS é calculado utilizando-se a expressão (11):

$$
R M S=\sqrt{\frac{\sum_{i=1}^{n}\left(S_{x}-S_{i}\right)^{2}}{n}}
$$

onde $S_{x}$ é o valor esperado para o espectro, $S_{i}$ é o valor efetivo do sinal na i-ésima medida, e $n$ é o total de medidas realizadas. Ele representa a variação do sinal em relação ao ajuste esperado, podendo ser comparado ao desvio padrão. Quanto maior o seu valor mais ruidoso o espectro.

A distância pico a pico é a diferença do valor máximo e mínimo de absorbância registrado, representando numericamente a qualidade do sinal. Quanto maior o seu valor, mais bem definidos os picos.

O estudo da razão entre a distância pico a pico e o RMS nos fornece a qualidade do sinal, sendo que quanto maior o valor desta razão, melhor a qualidade do espectro. A região espectral normalmente utilizada para o cálculo do RMS é entre $2050-1950 \mathrm{~cm}^{-1}$, devido à ausência de bandas nesta região, para amostras de tecido ósseo.

Como as energias para a irradiação laser utilizadas neste estudo promovem ablação na superfície das amostras, estas se tornam irregulares, o que acaba prejudicando a qualidade dos espectros obtidos, que ficam mais ruidosos. Uma das possíveis soluções para este problema, que não afeta a comparação entre os espectros das amostras irradiadas com os das não irradiadas, é aumentar o número de varreduras para as amostras irradiadas. Logo, o procedimento descrito foi repetido para uma amostra irradiada com densidade de energia de $14,7 \mathrm{~J} / \mathrm{cm}^{2}$, para que se pudesse obter o número ideal de varreduras para uma amostra irradiada. 


\subsubsection{Velocidade do espelho}

O parâmetro velocidade determina a velocidade de movimentação do espelho do interferômetro. O valor da velocidade é definido pelo tipo de detector, pelas informações que se deseja obter e pelo tipo de amostra. Uma alta velocidade consegue-se realizar um número de varreduras maior em menos tempo, entretanto isso pode aumentar o ruído do espectro. Para detectores tipo DTGS como o utilizado nesse estudo, a velocidade usual é $0,6329 \mathrm{~cm} / \mathrm{s}$, sendo este o valor utilizado na determinação dos demais parâmetros.

Para verificar se é possível aumentar a velocidade de movimentação do espelho, coletamos de uma mesma região da amostra dois espectros: um com a velocidade usual de $0,6329 \mathrm{~cm} / \mathrm{s}$, e outro com uma velocidade mais rápida, de $0,9393 \mathrm{~cm} / \mathrm{s}$. Este valor foi selecionado por ser o primeiro valor de velocidade maior que $0,6329 \mathrm{~cm} / \mathrm{s}$ que o programa de aquisição dos espectros permite selecionar.

Como realizado na determinação do número de varreduras calculou-se o valor da razão sinal ruído e determinou-se assim o espectro com melhor qualidade.

\subsection{Obtenção dos Espectros}

\subsubsection{Amostras não irradiadas}

Os espectros das três amostras não irradiadas foram obtidos e comparados entre si. As bandas encontradas foram identificadas e suas posições comparadas com as descritas na literatura. As áreas das bandas de cada espectro foram calculadas e normalizadas pela respectiva área sob a banda do fosfato (1300-900 $\mathrm{cm}^{-1}$ ). A média e o desvio padrão das áreas normalizadas de 
cada banda para as três amostras foram calculadas e posteriormente comparadas com as áreas das amostras irradiadas.

\subsubsection{Amostras irradiadas com laser de Er,Cr:YSGG}

O laser utilizado na irradiação das amostras foi o Er,Cr:YSGG (Waterlase $\circledR$, Biolaser - USA), pulsado e emitindo comprimento de onda de 2,78 $\mu \mathrm{m}$ (FIG. 20). A entrega do feixe é realizada por uma fibra óptica cristalina flexível (informações sobre composição são protegidas por patente) e uma peça de mão que permite diversas opções de pontas de safira na saída do feixe. O sistema também possui um jato d'água e de ar para resfriar as amostras durante a irradiação quando desejado. Outras características do equipamento são apresentadas na TAB. 9.

TABELA 9 - Especificações ópticas do sistema laser

\begin{tabular}{c|c}
\hline Classificação & Classe IV \\
\hline Meio & Er,Cr:YSGG \\
\hline Comprimento de Onda & $2,78 \mu \mathrm{m}$ \\
\hline Modo & Pulsado \\
\hline Taxa de repetição fixa & $20 \mathrm{~Hz}$ \\
\hline Potência Média & $0.0-6.0 \mathrm{~W}$ \\
\hline Energia do Pulso & $0-300 \mathrm{~mJ}$ \\
\hline Duração do Pulso & $140-150 \mu \mathrm{s}$ \\
\hline Diâmetro das pontas de & $200-1200 \mu \mathrm{s}$ \\
entrega & $8^{\circ}$ \\
\hline Divergência &
\end{tabular}




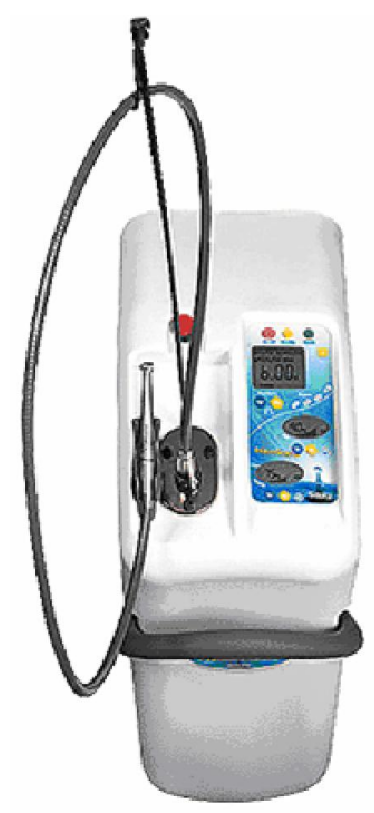

FIGURA 20 - Laser de Er,Cr:YSGG

A ponta de saída utilizada no experimento foi a S75 (FIG. 21), com diâmetro de $750 \mu \mathrm{m}$, e comprimento de $6 \mathrm{~mm}$, segundo especificações do fabricante.

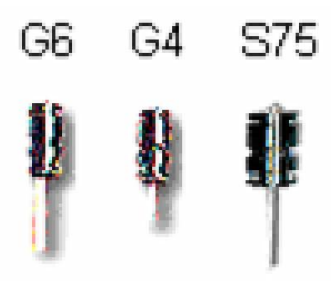

FIGURA 21 - Opções de pontas de safira para o acoplamento na peça de mão do laser de Er,Cr:YSGG. A ponta utilizada neste estudo foi a S75

Durante a irradiação a amostra foi deslocada por um translador motorizado com precisão de 0,5 $\mu \mathrm{m}$ (ESP300, Newport Corparation, Invine, CA, EUA) para que a irradiação fosse homogênea em toda sua superfície. A ponta do laser foi posicionada a aproximadamente $1 \mathrm{~mm}$ das amostras. A velocidade e a distância entre as linhas de irradiação utilizadas foram $13 \mathrm{~mm} / \mathrm{s}$ e 0,6 mm, respectivamente, para evitar a sobreposição de pulsos. Esses valores foram calculados considerando-se que a energia útil do feixe corresponde a $86 \%$ do valor fornecido pelo fabricante, pois como o perfil do feixe é gaussiano sua energia não é 
uniformemente distribuída, sendo mais intensa no centro do que nas bordas. Durante a irradiação as amostras não foram irradiadas

A FIG. 22 mostra o posicionamento do laser e da amostra durante a irradiação. Uma foto de uma amostra irradiada é apresentada na FIG. 23. Nota-se claramente as crateras de ablação causadas pelo laser

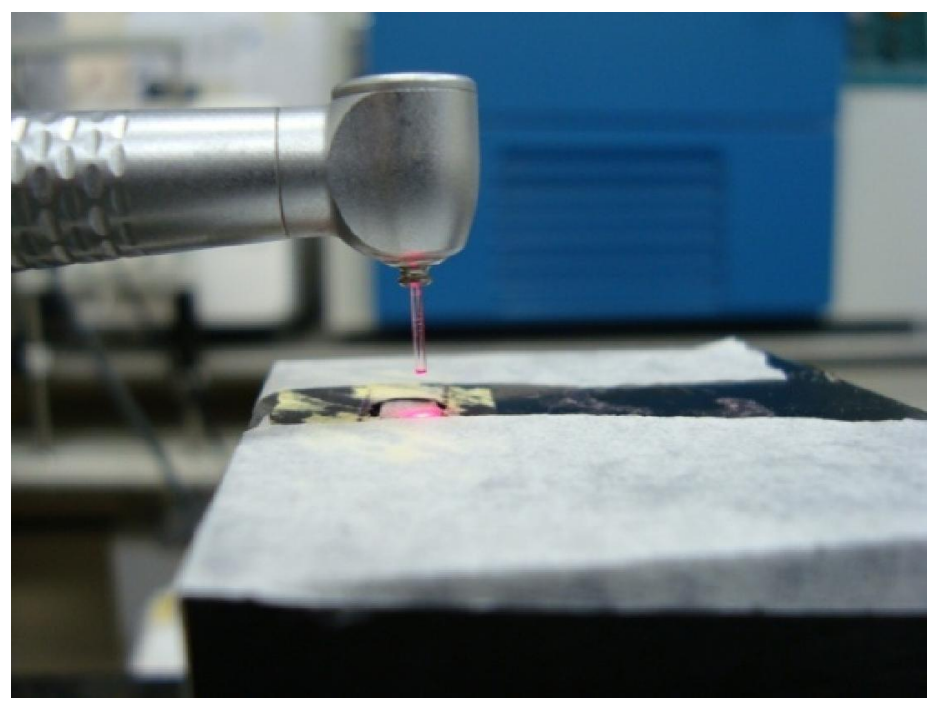

FIGURA 22 - Irradiação da amostra

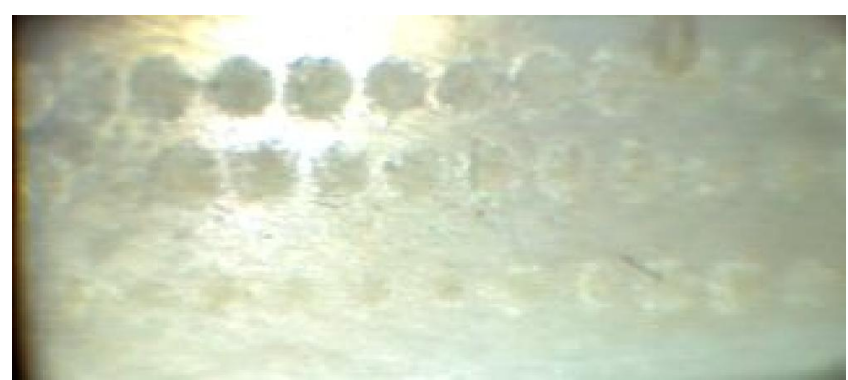

FIGURA 23 - Amostra irradiada

As densidades utilizadas são apresentadas na TAB. 10. Antes e depois das irradiações a energia de saída do laser foi medida utilizando-se um medidor de energia (power-energy meter - Fieldmaster, Coherent, CA, EUA), sendo desprezada a potência média indicada no monitor do laser.

As 15 amostras foram divididas em cinco grupos com três amostras conforme a densidade de energia utilizada na irradiação, sendo o grupo 1 o grupo 
controle formado pelas três amostras de osso não irradiado. O diâmetro do feixe laser considerado para o cálculo da densidade de energia foi o diâmetro da fibra $(750 \mu \mathrm{m})$, pois, apesar da energia não ser uniformemente distribuída, ela é distribuída em toda área da fibra.

TABELA 10 - Grupos de estudo divididos conforme a densidade de energia com a qual as amostras foram irradiadas.

\begin{tabular}{c|c}
\hline Grupo & Fluência $\left(\mathbf{J} / \mathbf{c m}^{2}\right)$ \\
\hline 1 & 0 \\
\hline 2 & 2,7 \\
\hline 3 & 5,7 \\
\hline 4 & 8,1 \\
\hline 5 & 12,2 \\
\hline 6 & 14,7 \\
\hline
\end{tabular}

As áreas das bandas de interesse de cada uma das três amostras dos seis grupos de estudo foram calculadas. As posições e larguras das bandas também foram medidas. Para a comparação entre os grupos foi considerado o valor da média e do desvio padrão das três amostras dos grupos. A estatística utilizada foi ANOVA, com 0,05 de significância. A identificação foi feita com base da na TAB. 2, TAB. 3, TAB. 4 e TAB. 5 (seção 3.4.1), que apresentam as posições das bandas de absorção dos componentes do tecido ósseo e seu modos de vibração.

\subsection{Estudo das formas de analise dos espectros}

\subsubsection{Identificação das Bandas}

Os espectros de uma amostra não irradiada (controle) foram estudados para que as bandas encontradas fossem identificadas, e pudéssemos definir a melhor forma de análise dos espectros. 


\subsubsection{Reprodutibilidade do Espectro}

O osso, assim como a maior parte dos materiais biológicos, não é totalmente homogêneo, podendo haver significativas diferenças de composição de uma região para outra da amostra. Assim, para uma caracterização precisa do osso é necessário verificar a reprodutibilidade de um espectro, para sabermos as limitações da técnica.

A reprodutibilidade dos espectros foi verificada obtendo-se seis espectros de uma mesma amostra de osso não irradiado. Estes espectros foram obtidos de três regiões diferentes da amostra, uma vez que, repetindo o procedimento descrito anteriormente, dois espectros foram retirados sem que a amostra sofresse qualquer alteração em sua posição. Sem qualquer tratamento matemático, os espectros obtidos foram comparados: primeiramente região a região, e depois todos juntos.

\subsubsection{Normalização dos Espectros}

Para a realização de uma analise semiquantitativa é necessária a normalização dos espectros. Portanto, três espectros de uma mesma amostra de osso não irradiado foram comparados quando normalizados de diferentes modos: pela intensidade da banda do fosfato $\left(1300-900 \mathrm{~cm}^{-1}\right)$; pela área sob a banda do fosfato $\left(1300-900 \mathrm{~cm}^{-1}\right)$; e normalizados pela área total do espectro.

\subsubsection{Definição das posições das bandas}

Verificou-se a possibilidade de se utilizar o método da segunda derivada para determinar a posição das bandas com maior precisão. Conforme ilustrado na FIG. 24, a segunda derivada do espectro fornece um pico negativo no espectro de absorção para cada banda. As vantagens e praticidade do método ficam mais evidentes em espectros complexos (FIG. 25) 


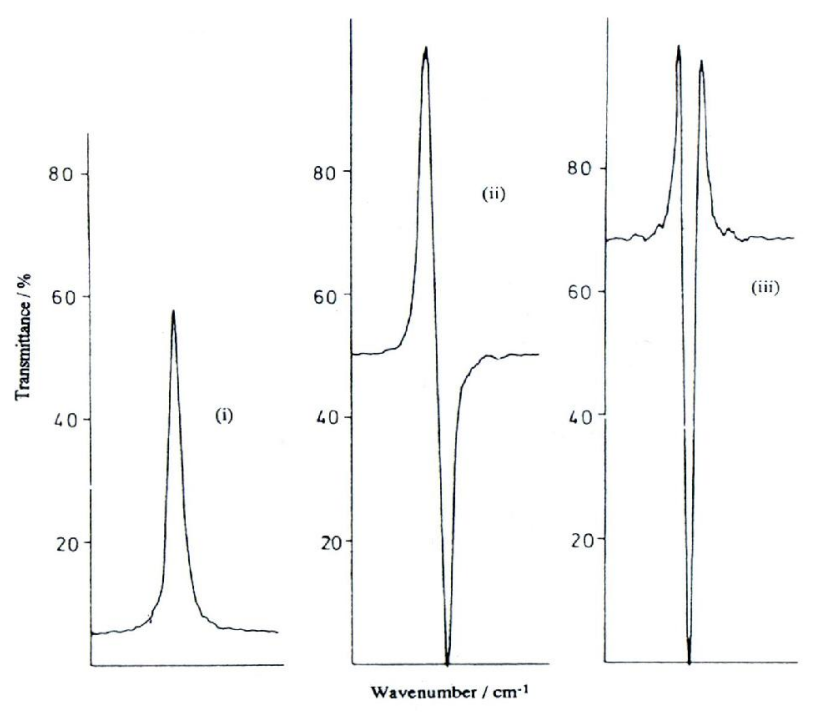

FIGURA 24 - Exemplo da segunda derivada de uma banda: $(A)$ banda de absorção; (B) primeira derivada; $(C)$ segunda derivada.

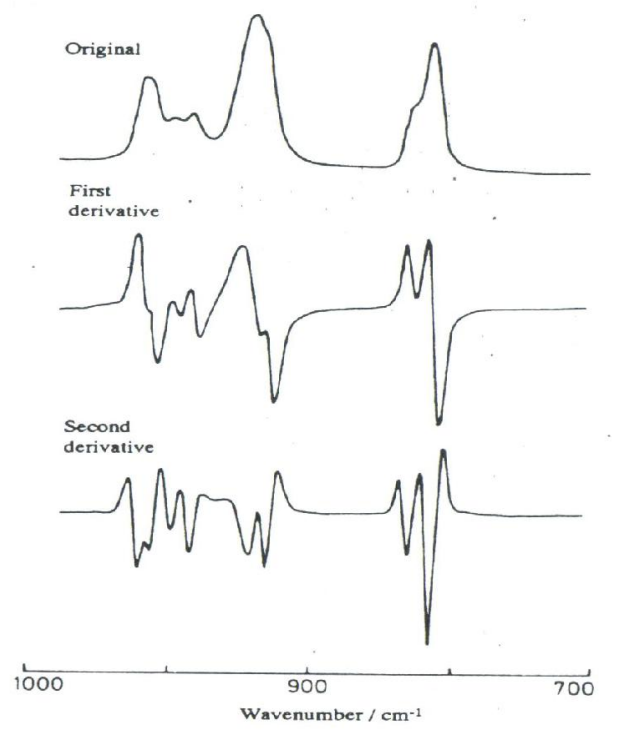

FIGURA 25 - Exemplo das derivadas de um espectro: (A) espectro original; (B) primeira derivada; $(C)$ segunda derivada.

\subsubsection{Cálculo da área das bandas}

A maior dificuldade no cálculo das áreas das bandas ocorre devido a sobreposição das mesmas, o que torna difícil saber onde começa e termina a área de uma banda. Foram testados dois métodos para o calculo das áreas das bandas: por ajustes de gaussianas; e por integração após traçar o baseline. 
O método do ajuste de gaussianas supõe que as bandas são descritas como curvas gaussianas. Logo, a sobreposição das bandas resulta da sobreposição de duas ou mais gaussianas. Portanto, basta encontrar as gaussianas que sobrepostas descrevem o espectro para determinar a contribuição de cada componente na sobreposição. O método é melhor entendido observando-se a FIG. 26. A área sob a banda corresponde à área sob a respectiva curva gaussiana.

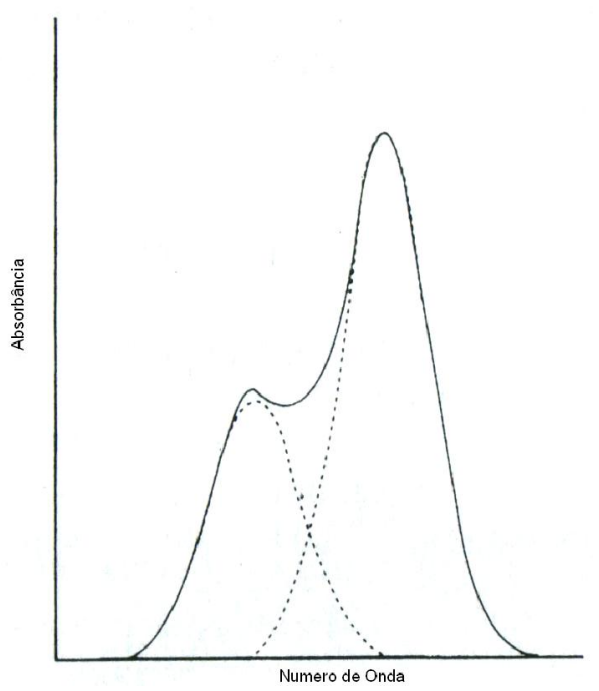

FIGURA 26- Exemplo de ajuste de Gaussianas em bandas sobrepostas.

A principal vantagem deste método é que ele permite uma análise quantitativa dos componentes das amostras.

No método de integração, primeiramente é traçado a baseline das bandas de interesse (FIG. 27A). Em seguida é realizada a subtração deste ajuste, o que faz com que as bandas de interesse tenham sua base coincidente com o zero do eixo das ordenadas (FIG 27B), e com isso a área sob a banda pode ser obtida calculando-se a integral da banda (área sob a curva). 
(A)

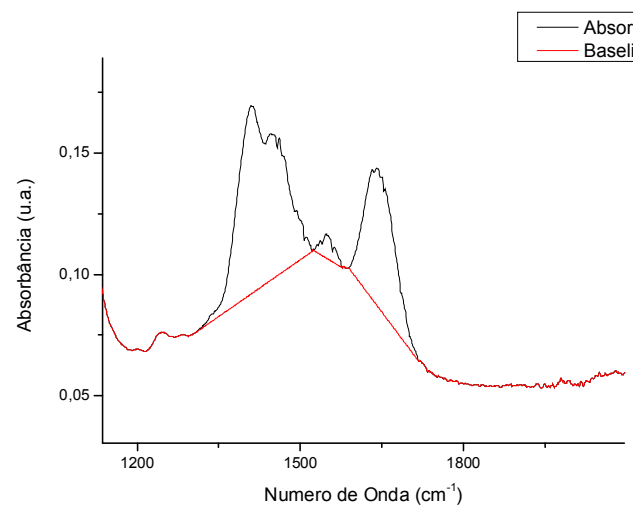

(B)

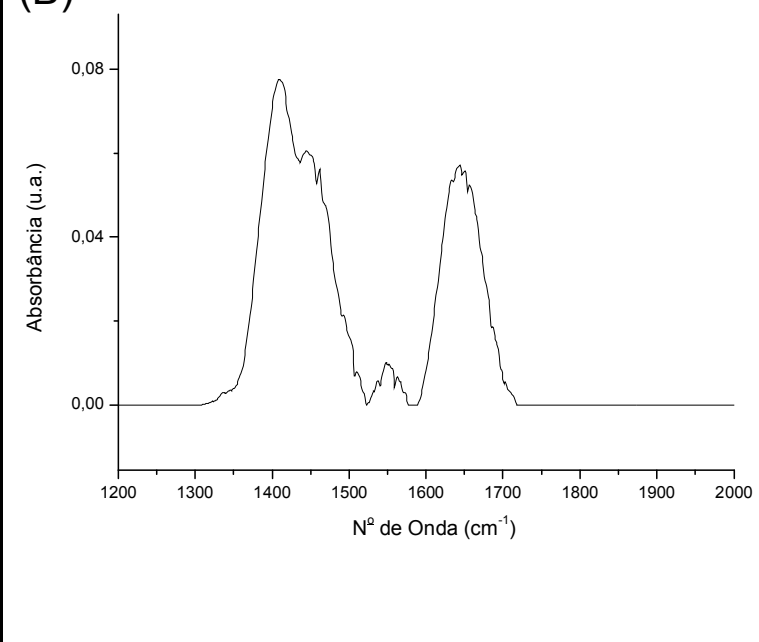

FIGURA 27 - Método de integração: (A) baseline de três bandas da região das amidas; (B) bandas após subtração do baseline

Este método apresenta como desvantagens a perda de informações sobre a banda, já que não é calculada sua área total, mas sim apenas uma parte da área sob a banda, que se destaca nas sobreposições. Por este motivo, o método só permite analises semiquantitativas.

\subsubsection{Método estatístico}

As análises foram realizadas utilizando o software Origin 8.0. Os dados analisados foram as áreas sob as bandas dos diferentes grupos para cada componente ósseo estudado.

Optou-se por utilizar a análise de variâncias (ANOVA) com $5 \%$ de significância. Para isso, a normalidade dos dados foi verificada pelo teste de Shapiro-Wilk, e a igualdade entre as variâncias com o teste de Levenell, ambos com $5 \%$ de significância. A independência dos dados foi garantida pela forma como o experimento foi elaborado. A comparação entre os valores das médias das áreas de cada grupo foi realizada pelo teste de Tukey com significância de $5 \%$. 


\section{RESULTADOS}

\subsection{Parâmetros do ATR-FTIR}

\subsubsection{Resolução}

Os espectros obtidos de uma mesma região com diferentes resoluções são apresentados na FIG. 27, FIG. 28, e FIG. 29.

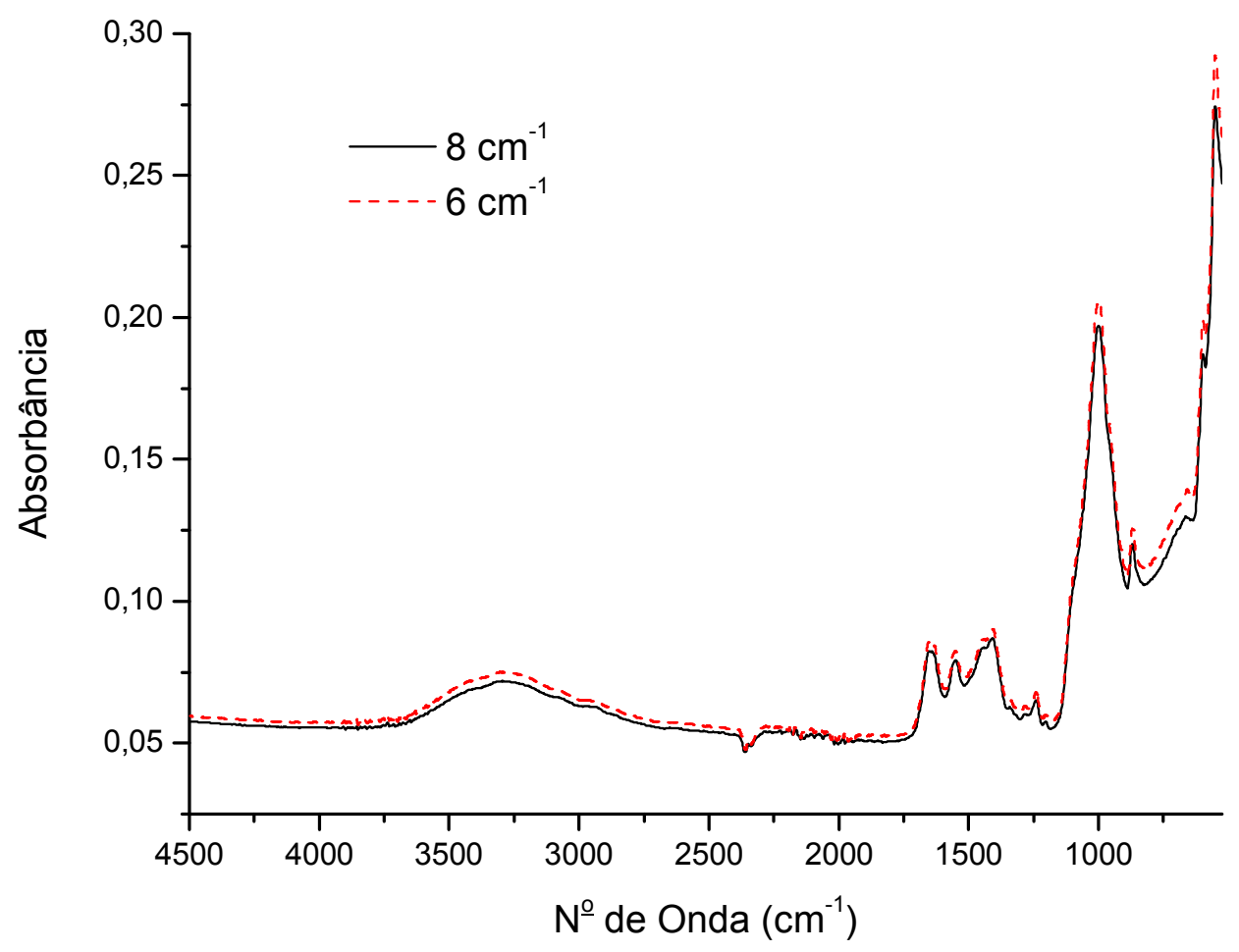

FIGURA 27 - Espectros obtidos com resolução de $8 \mathrm{~cm}^{-1}$ e $6 \mathrm{~cm}^{-1}$ para uma mesma região da amostra não irradiada.

Na FIG. 27 verifica-se que não houve diferenças expressivas entre as bandas encontradas, nem na qualidade dos espectros quando obtidos com resolução de $8 \mathrm{~cm}^{-1}$ ou $6 \mathrm{~cm}^{-1}$. Portanto, pela FIG. 27 a resolução de $6 \mathrm{~cm}^{-1}$ é a mais adequada, visto que é a mais precisa. 


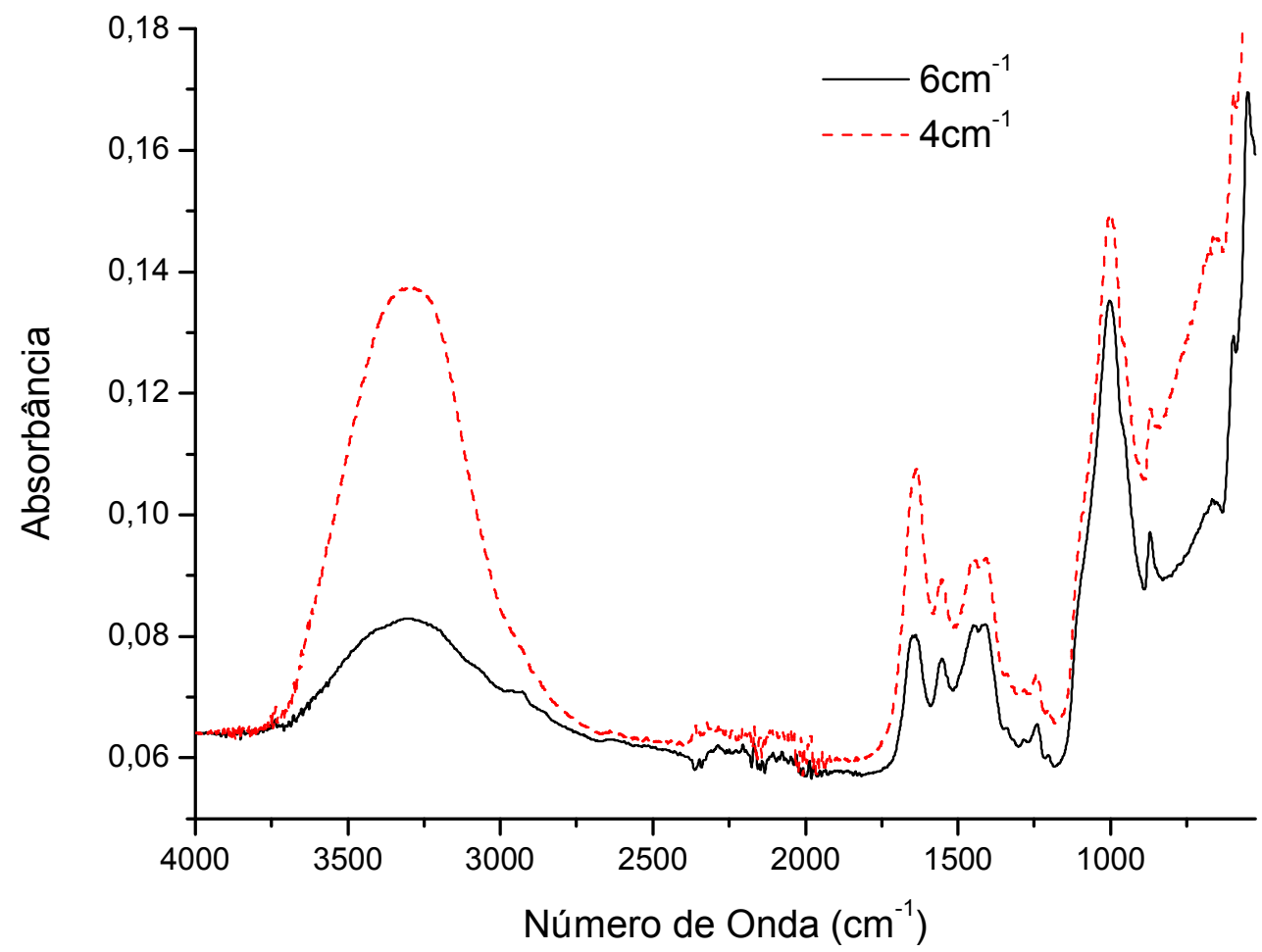

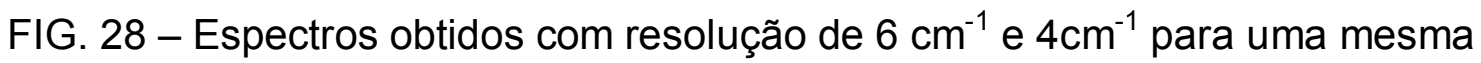
região da amostra não irradiada da FIG. 27.

Na FIG. 28 verifica-se que ao aumentar a resolução do equipamento para $4 \mathrm{~cm}^{-1}$, embora mais ruído fosse esperado, não perdeu-se qualidade de sinal quando comparado com o espectro obtido com a resolução de $6 \mathrm{~cm}^{-1}$. 


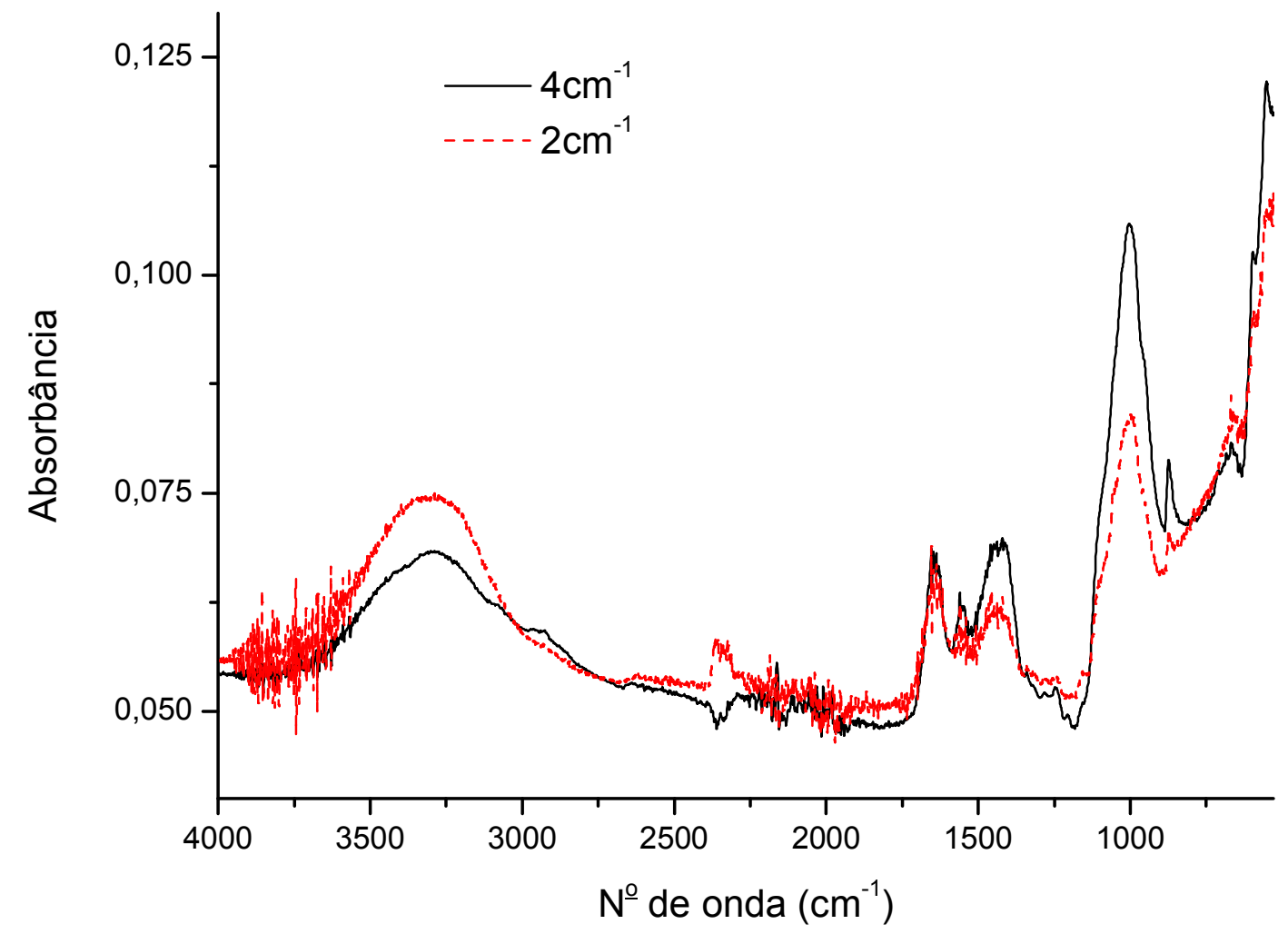

FIGURA 29 - Espectros obtidos com resolução de $4 \mathrm{~cm}^{-1}$ e $2 \mathrm{~cm}^{-1}$ para uma mesma região da amostra não irradiada da FIG. 27 e FIG. 28.

A FIG. 29 mostra um espectro obtido com resolução de $2 \mathrm{~cm}^{-1}$, que apesar de mais precisa, faz com que o espectro obtido seja ruidoso quando comparado com o espectro obtido com uma resolução de $4 \mathrm{~cm}^{-1}$. O ruído no espectro prejudica a análise, pois dificulta determinar a posição das bandas, oculta bandas de baixa intensidade, além de aumentar a imprecisão das áreas sob as bandas. Portanto, a resolução de $2 \mathrm{~cm}^{-1}$ não é adequada para as amostras de analisadas neste experimento.

Verificou-se nas FIG. 27 e FIG. 28, que entre as resoluções de $8 \mathrm{~cm}^{-1}$, $6 \mathrm{~cm}^{-1}$ e $4 \mathrm{~cm}^{-1}$ não há diferenças expressivas entre os espectros, portanto a melhor resolução foi a de $4 \mathrm{~cm}^{-1}$, por ser a mais precisa, dentre as que apresentaram espectros com boa qualidade de sinal. 


\subsubsection{Número de varreduras}

Os valores de RMS, distância pico a pico assim como a razão entre eles para os espectros das amostras não irradiadas são apresentados na TAB. 12. As diferentes cores das linhas da tabela representam diferentes regiões analisadas em uma mesma amostra, sendo que em negrito é destacado o resultado de melhor relação sinal/ruído para cada região.

TABELA 12 - Valores de RMS, distância pico a pico e razão entre eles para cada espectro da amostra não irradiada. As diferentes cores das linhas da tabela representam diferentes regiões analisadas em uma mesma amostra, sendo que em negrito é enfatizado o resultado de melhor qualidade para cada região.

\begin{tabular}{c|c|c|c|c}
\hline Medidas & $\begin{array}{c}\text { Número de } \\
\text { varreduras }\end{array}$ & RMS & $\begin{array}{c}\text { Distância } \\
\text { pico a pico }\end{array}$ & Razão \\
\hline 1 & 40 & 0,0018552 & 0,0085124 & 4,59 \\
\hline 2 & 80 & 0,0012500 & 0,0058650 & $\mathbf{4 , 6 9}$ \\
\hline 3 & 80 & 0,0012544 & 0,0057768 & 4,61 \\
\hline 4 & 120 & 0,0011982 & 0,0055640 & $\mathbf{4 , 6 4}$ \\
\hline 5 & 40 & 0,0018322 & 0,0093370 & $\mathbf{5 , 1 0}$ \\
\hline 6 & 20 & 0,0024272 & 0,0104402 & 4,30 \\
\hline
\end{tabular}

Conforme o esperado, quando observamos os espectros correspondentes a uma mesma região, o obtido com maior número de varreduras sempre apresentou melhor qualidade, ou seja, maior valor da razão da distância pico a pico pelo RMS. Entretanto essa diferença é mais notória quando comparamos a qualidade do espectro obtido com 20 e 40 varreduras, visto que a diferença entre as razões obtidas é de quase $16 \%$. Nos demais casos a diferenças entre as razões não foram superiores a $3 \%$, sendo de 2,3\% quando comparamos o espectro obtido com 40 e 80 varreduras, e menor que 1\% quando foram realizadas 80 e 120 varreduras. Portanto, para amostras de osso não irradiado, 40 varreduras são o suficiente para obter um espectro com boa qualidade, não sendo necessário aumentar o número de varreduras e consequentemente o tempo de aquisição. 
Na TAB. 13 são apresentados os valores de RMS, distancia pico a pico e a razões entre eles obtidos para os espectros das amostras irradiadas, obtidos com diferentes números de varreduras.

TABELA 13 - Valores de RMS, distância pico a pico e razão entre eles para cada espectro da amostra irradiada. As diferentes cores das linhas da tabela representam diferentes regiões analisadas em uma mesma amostra, sendo que em negrito é enfatizado o resultado de melhor qualidade para cada região.

\begin{tabular}{c|c|c|c|c}
\hline Medida & $\begin{array}{c}\text { Número de } \\
\text { varreduras }\end{array}$ & RMS & $\begin{array}{c}\text { Distância } \\
\text { pico a pico }\end{array}$ & Razão \\
\hline 1 & 40 & 0,0013199 & 0,0056650 & $\mathbf{4 , 2 9}$ \\
\hline 2 & 80 & 0,0013124 & 0,0055753 & 4,25 \\
\hline 3 & 80 & 0,0016405 & 0,0084099 & 5,13 \\
\hline 4 & 120 & 0,0010287 & 0,0053074 & $\mathbf{5 , 1 6}$ \\
\hline
\end{tabular}

Para as amostras irradiadas, não foi observada nenhuma diferença de sinal relevante entre os diferentes números de varreduras testadas, sendo a diferença da qualidade de sinal obtida com 120 e 80 varreduras é menor que 1\%, e entre 40 e 80 varreduras de 1\%. Apesar ser esperado que o espectro obtido com 80 varreduras tivesse melhor qualidade do que o com 40 varreduras isso não foi observado, entretanto, como a diferença entre eles é pequena, este fato não indica uma melhor qualidade do espectro obtido com 40 varreduras, mas sim que não há diferença entre a qualidade dos espectros.

Diferentemente do que se esperava, não é necessário aumentar o número de varreduras para as amostras irradiadas, visto que o espectro obtido com 40 varreduras tem praticamente a mesma qualidade que o obtido com 80 e 120 varreduras. 


\subsubsection{Velocidade do espelho}

Os valores de RMS, distância pico a pico e sua razão obtidos para os espectros obtidos com a velocidade do espelho ajusta em $0,6329 \mathrm{~cm} / \mathrm{s}$ e $0,9494 \mathrm{~cm} / \mathrm{s}$ são apresentados na TAB. 14. Em negrito é enfatizado o resultado de melhor qualidade.

TABELA 14 - Valores de RMS, distância pico a pico e razão entre eles para os espectros obtidos com diferentes velocidades de movimentação do espelho.

\begin{tabular}{c|c|c|c|c}
\hline Medida & $\begin{array}{c}\text { Velocidade do } \\
\text { Espelho }\end{array}$ & RMS & $\begin{array}{c}\text { Distância } \\
\text { pico a pico }\end{array}$ & Razão \\
\hline 1 & 0,9494 & 0,0026054 & 0,0127727 & 4,90 \\
\hline 2 & 0,6329 & 0,0012054 & 0,0065688 & $\mathbf{5 , 4 5}$ \\
\hline
\end{tabular}

Verificou-se que, conforme o esperado, o espectro de melhor qualidade foi o obtido quando o espelho foi movimentado com a velocidade de 0,6329 cm/s, ou seja, com a menor velocidade, sendo a diferença entre as razões é maior que $10 \%$. Portanto, na aquisição dos espectros o espelho do interferômetro foi movimentado com velocidade de $0,6329 \mathrm{~cm} / \mathrm{s}$.

\subsection{Identificação das Bandas}

Determinadas as melhores condições para a aquisição dos espectros, as bandas encontradas para uma amostra de osso não irradiado foram identificadas. A FIG. 30 apresenta um espectro de osso não irradiado, a TAB. 15 apresenta a posição aproximada do pico das bandas encontradas. 


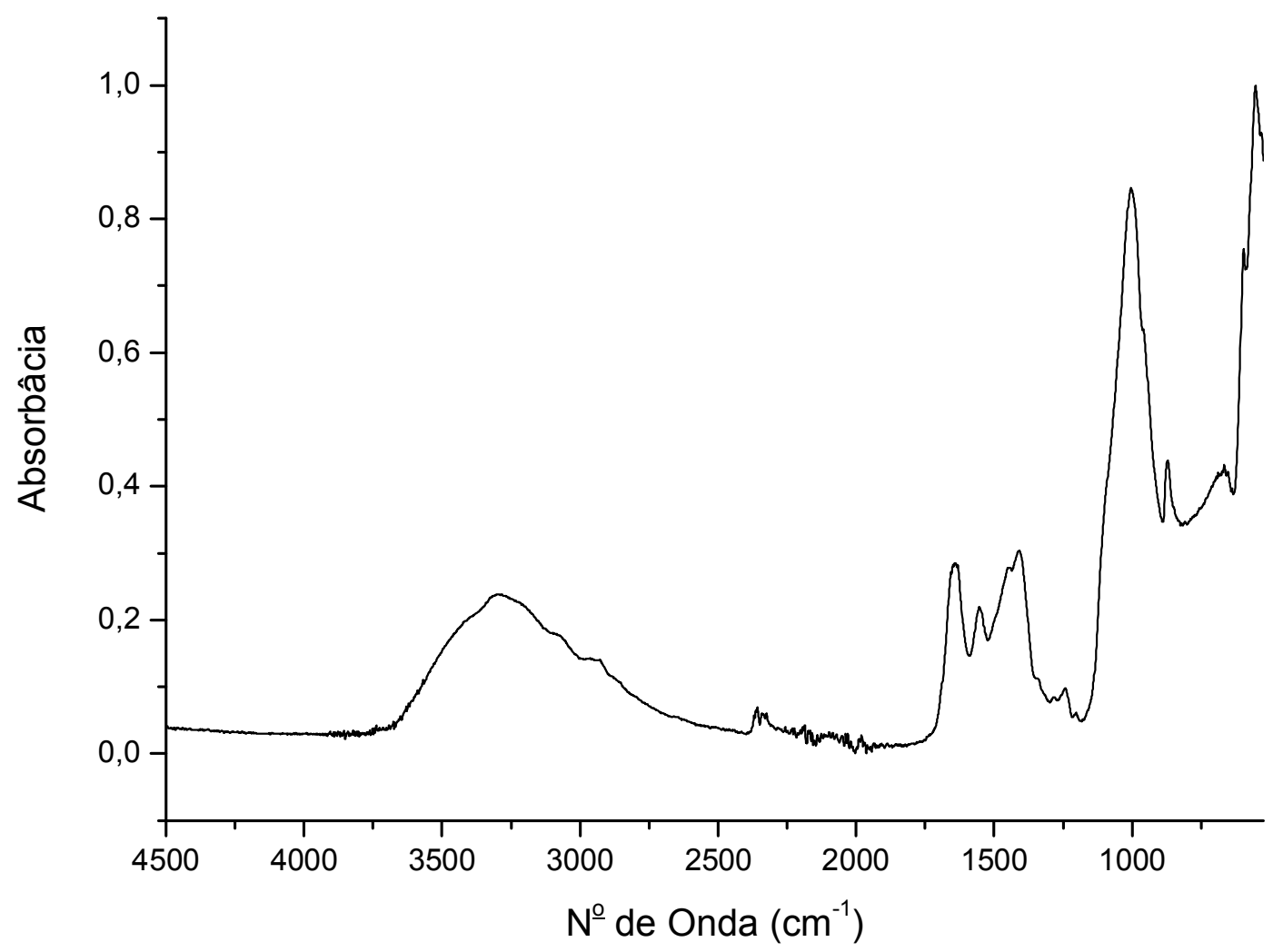

FIGURA 30 - Espectro encontrado para uma amostra de osso não irradiado. 
TABELA 15 - Posição aproximada e identificação das bandas encontradas em um espectro obtido de uma amostra de osso não irradiado.

\begin{tabular}{|c|c|c|}
\hline $\begin{array}{c}\text { Posição aproximada } \\
\text { da Banda }\left(\mathrm{cm}^{-1}\right)\end{array}$ & Componente & Modos de Vibração \\
\hline 3450 & $\mathrm{H}_{2} \mathrm{O}$ adsorvida & Estiramento simétrico \\
\hline 3300 & $\mathrm{H}_{2} \mathrm{O}$ & $v_{1}+2 v_{2}$ \\
\hline 3212 & $\mathrm{H}_{2} \mathrm{O}$ & $v_{1}+2 v_{2}$ \\
\hline 3083 & Amida B & \\
\hline 2950 & $\mathrm{C}-\mathrm{H}$ & Estiramento \\
\hline 2853 & $\mathrm{C}-\mathrm{H}^{-}$ & Estiramento \\
\hline 1642 & Amida $\mathrm{I}+\mathrm{H}_{2} \mathrm{O}$ adsorvida & - \\
\hline 1553 & Amida II $+\mathrm{CO}_{3}^{2-}$ & Estiramento assimétrico $v_{3}$ \\
\hline 1445 & $\mathrm{CO}_{3}{ }^{2-}$ & Estiramento assimétrico $v_{3}$ \\
\hline 1409 & $\mathrm{CO}_{3}{ }^{2-}$ & Estiramento assimétrico $v_{3}$ \\
\hline 1335 & Colágeno & - \\
\hline 1283 & Colágeno & - \\
\hline 1240 & Amida III & - \\
\hline 1203 & Colágeno & - \\
\hline 1100 & $\mathrm{PO}_{4}^{3-}$ & Estiramento assimétrico $v_{3}$ \\
\hline 1003 & $\mathrm{PO}_{4}{ }^{3-}$ & Estiramento assimétrico $v_{3}$ \\
\hline 957 & $\mathrm{PO}_{4}{ }^{3-}$ & $v_{1}$ \\
\hline 870 & $\mathrm{CO}_{3}{ }^{2-}$ & Deformação assimétrica $v_{2}$ \\
\hline 676 & $\mathrm{OH}^{-}$ & Libração \\
\hline 595 & $\mathrm{PO}_{4}^{3-}$ & Deformação assimétrica $v_{4}$ \\
\hline
\end{tabular}

São constatadas pequenas diferenças entre as posições centrais das bandas obtidas em relação à posição das bandas reportadas na literatura (TAB. 2, TAB. 3, TAB. 4, TAB. 5) para os mesmos componentes. Entretanto, isso se deve a diferenças entre os equipamentos e técnicas estilizadas.

Da FIG. 31 a FIG. 35 são apresentados o espectro na amostra de ossos não irradiado em diferentes regiões, com destaque para as bandas encontradas. 
Na FIG. 31 observa-se a região espectral de $4000 \mathrm{~cm}^{-1}$ a $2500 \mathrm{~cm}^{-1}$, região que corresponde aos modos de vibração da molécula de água, do estiramento C$\mathrm{H}$, como apresentado na TAB. 4, seção 3.4.1. Existe uma única grande banda na região, formada pela sobreposição das bandas de absorção destes componentes. É identificado um 'ombro' na região espectral de $3500-3400 \mathrm{~cm}^{-1}$, que pode ser tanto da vibração $v_{3}$ da molécula de água, quanto do estiramento da molécula O$\mathrm{H}$, ou devido a sobreposição de ambos, não se pode afirmar, visto a incerteza na posição das bandas e a variação que ocorre entre os diferentes equipamentos espectrômetros. O centro da banda (em aproximadamente $3300 \mathrm{~cm}^{-1}$ ), e a primeira 'ondulação' a sua direita (em aproximadamente $3200 \mathrm{~cm}^{-1}$ ), corresponde a sobreposição dos modos de vibração $v_{1}$ e $v_{2}$ da molécula de água. $O$ primeiro 'ombro' do lado direito, localizado em aproximadamente $3080 \mathrm{~cm}^{-1}$ corresponde ao modo de vibração da Amida B, o os dois 'ombros' subsequentes em aproximadamente $2950 \mathrm{~cm}^{-1}$ e $2850 \mathrm{~cm}^{-1}$ corresponde ao estiramento da molécula $\mathrm{C}-\mathrm{H}$. 


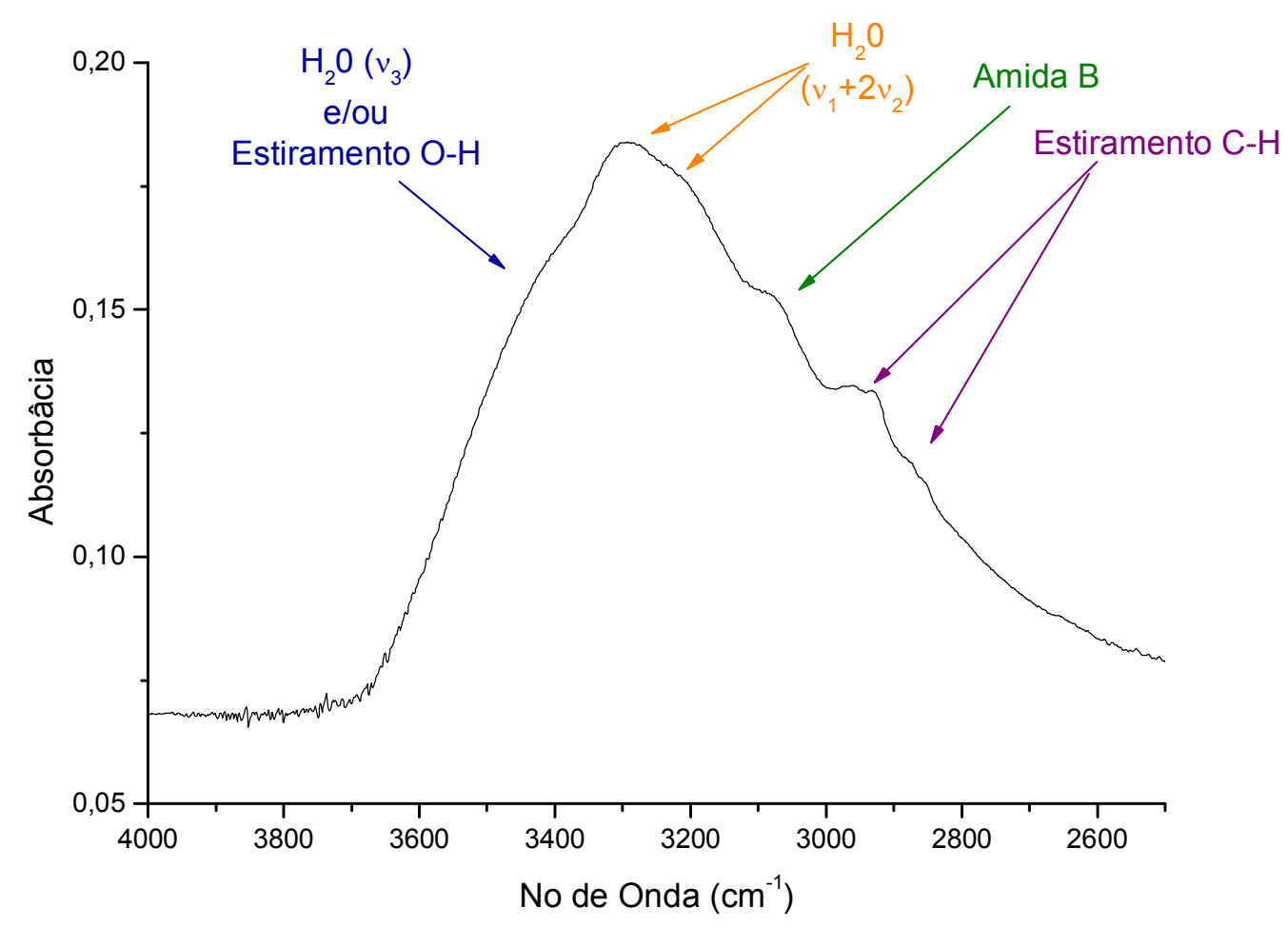

FIGURA 31 - Espectro de tíbia não irradiada na região espectral de $4000 \mathrm{~cm}^{-1}$ a $2500 \mathrm{~cm}^{-1}$.

A FIG. 32 apresenta a região espectral de $1750 \mathrm{~cm}^{-1}$ a $1250 \mathrm{~cm}^{-1}$, onde estão localizadas as bandas das amidas, água, carbonato e colágeno, como apresentado na TAB. 5, seção 3.4.1. Novamente, percebemos que todas as bandas estão sobrepostas. A primeira banda, com centro próximo a $1640 \mathrm{~cm}^{-1}$, corresponde a sobreposição da banda da água com a banda da amida I, não sendo possível identificar a contribuição de cada componente na formação da banda. O mesmo ocorre com a segunda banda observada, com centro em aproximadamente $1550 \mathrm{~cm}^{-1}$. Tanto a amida II quanto o modo de vibração $v_{4}$ do carbonato possuem bandas de absorção nesta posição, então não foi possível saber a contribuição de cada componente na formação da banda. $\operatorname{Em~} 1445 \mathrm{~cm}^{-1} \mathrm{e}$ $1405 \mathrm{~cm}^{-1}$, aproximadamente, verifica-se os centro das bandas de absorção do estiramento simétrico do carbonato e, em $1335 \mathrm{~cm}^{-1}$, observa-se uma banda referente ao colágeno. 


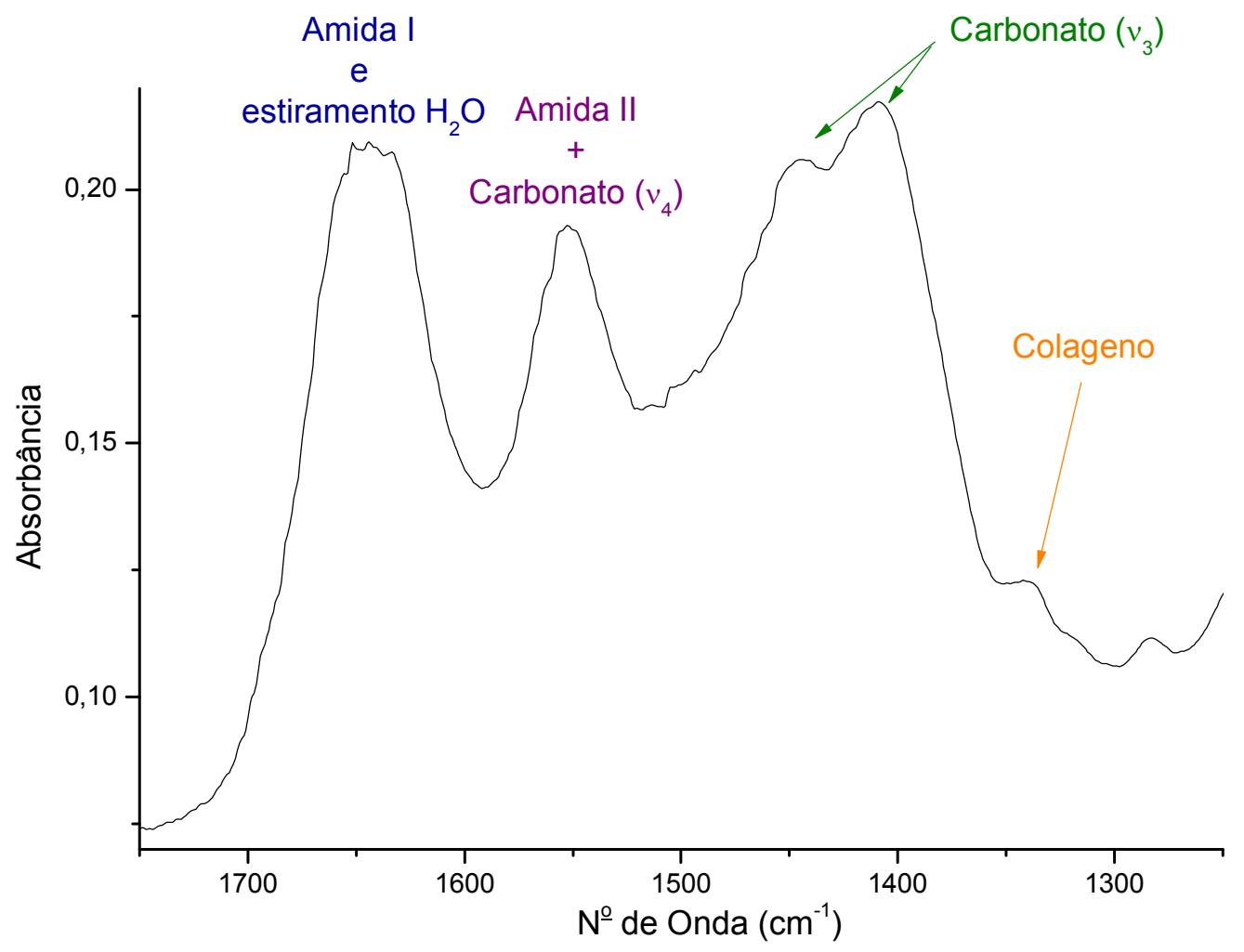

FIGURA 32 - Espectro de tíbia não irradiada na região espectral de $1750 \mathrm{~cm}^{-1}$ a $1250 \mathrm{~cm}^{-1}$.

Na FIG. 33, observa-se a região espectral de $1300 \mathrm{~cm}^{-1}$ a $1180 \mathrm{~cm}^{-1}$. Nesta região ainda são encontrados bandas do matriz orgânica do osso. As bandas com posição central em aproximadamente $1280 \mathrm{~cm}^{-1}$ e $1203 \mathrm{~cm}^{-1}$ correspondem a bandas de absorção da estrutura colágenas, e em $1240 \mathrm{~cm}^{-1}$ é verifica a presença da banda de absorção referente à amida III. 


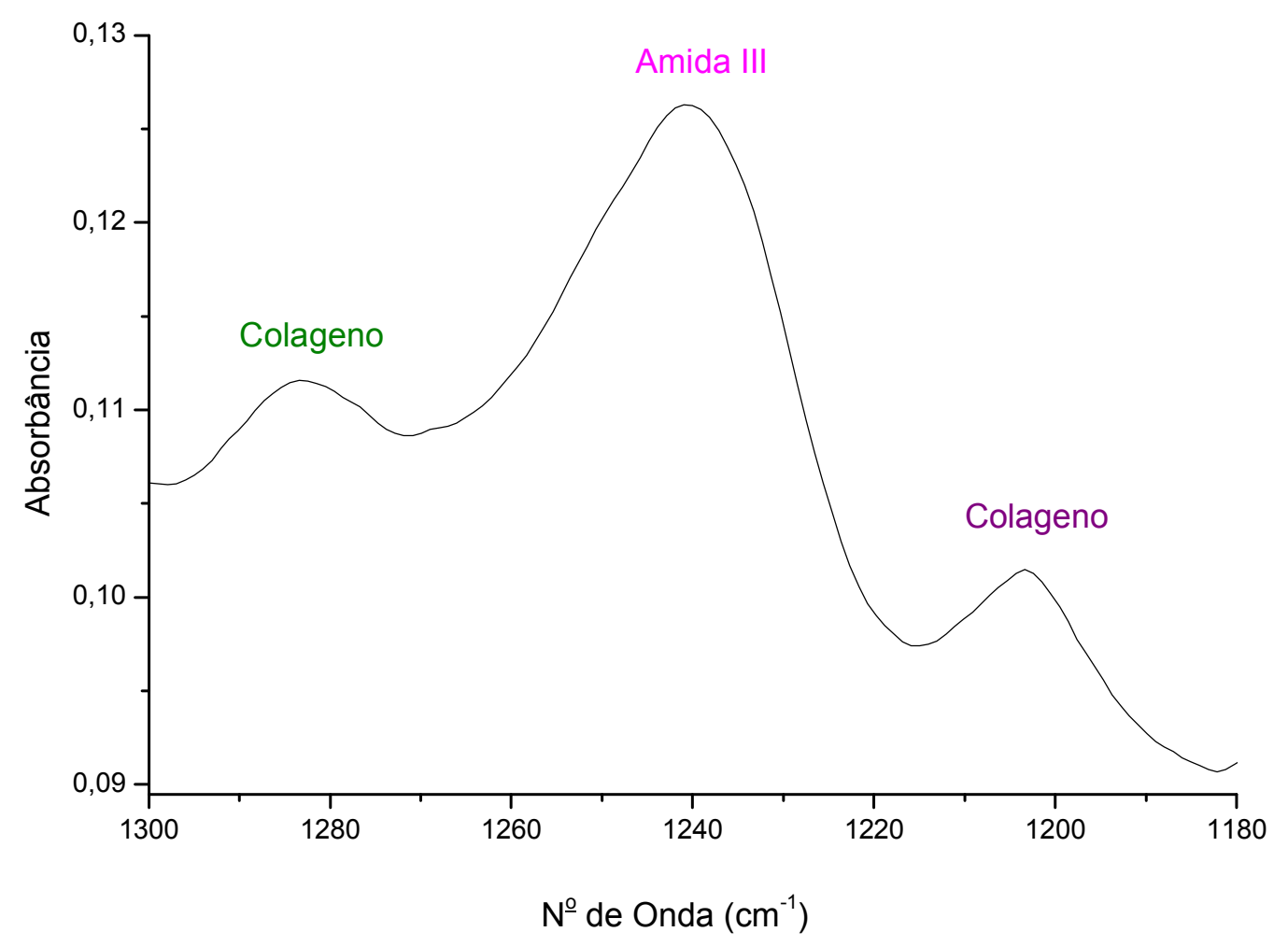

FIGURA 33 - Espectro de tíbia não irradiada na região espectral de $1300 \mathrm{~cm}^{-1}$ a $1180 \mathrm{~cm}^{-1}$.

Na FIG. 34 o espectro na região de $1180 \mathrm{~cm}^{-1}$ a $800 \mathrm{~cm}^{-1}$ é apresentado. Nesta região se encontram a maioria das bandas de absorção do fosfato, e no caso do tecido ósseo é possível identificar três delas: com centros em aproximadamente $1100 \mathrm{~cm}^{-1}$ e $1003 \mathrm{~cm}^{-1}$, correspondendo aos modos de vibração $v_{3}$, e em aproximadamente $960 \mathrm{~cm}^{-1}$, correspondendo ao e ao modo de vibração $v_{1}$.Também é possível identificar uma banda com centro em $870 \mathrm{~cm}^{-1}$, referente ao modo de vibração $v_{2}$ do carbonato. 


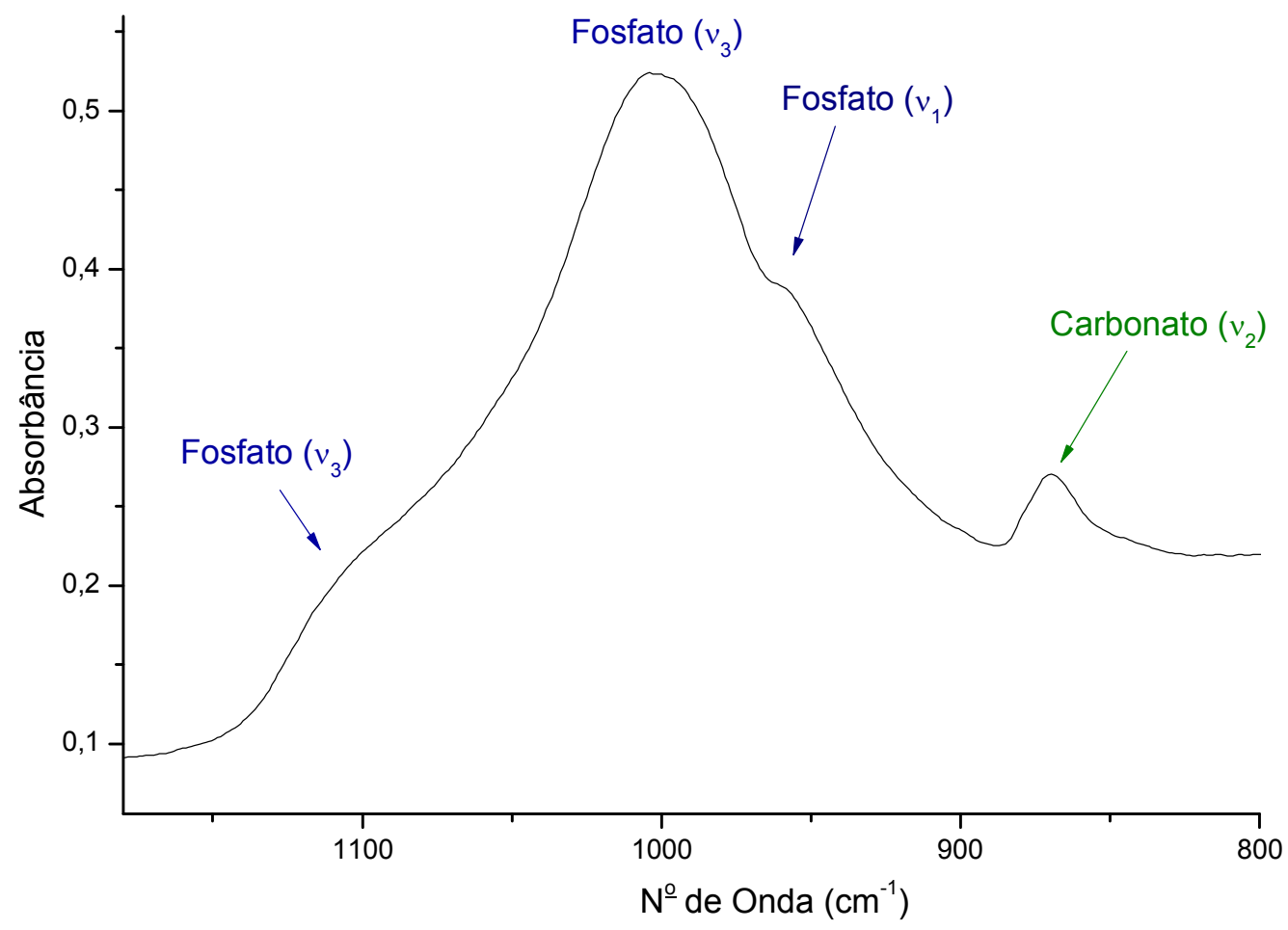

FIGURA 34 - Espectro de tíbia não irradiada na região espectral de 1180 a $800 \mathrm{~cm}^{-1}$.

A última parte da região espectral é apresentada na FIG. 35, e vai de 850 $\mathrm{cm}^{-1}$ a $550 \mathrm{~cm}^{-1}$. Nela é possível identificar duas bandas: a libração $\mathrm{OH}^{-}$, em aproximadamente $670 \mathrm{~cm}^{-1}$, e o modo de vibração $v_{4}$ do fosfato, em aproximadamente $595 \mathrm{~cm}^{-1}$. 


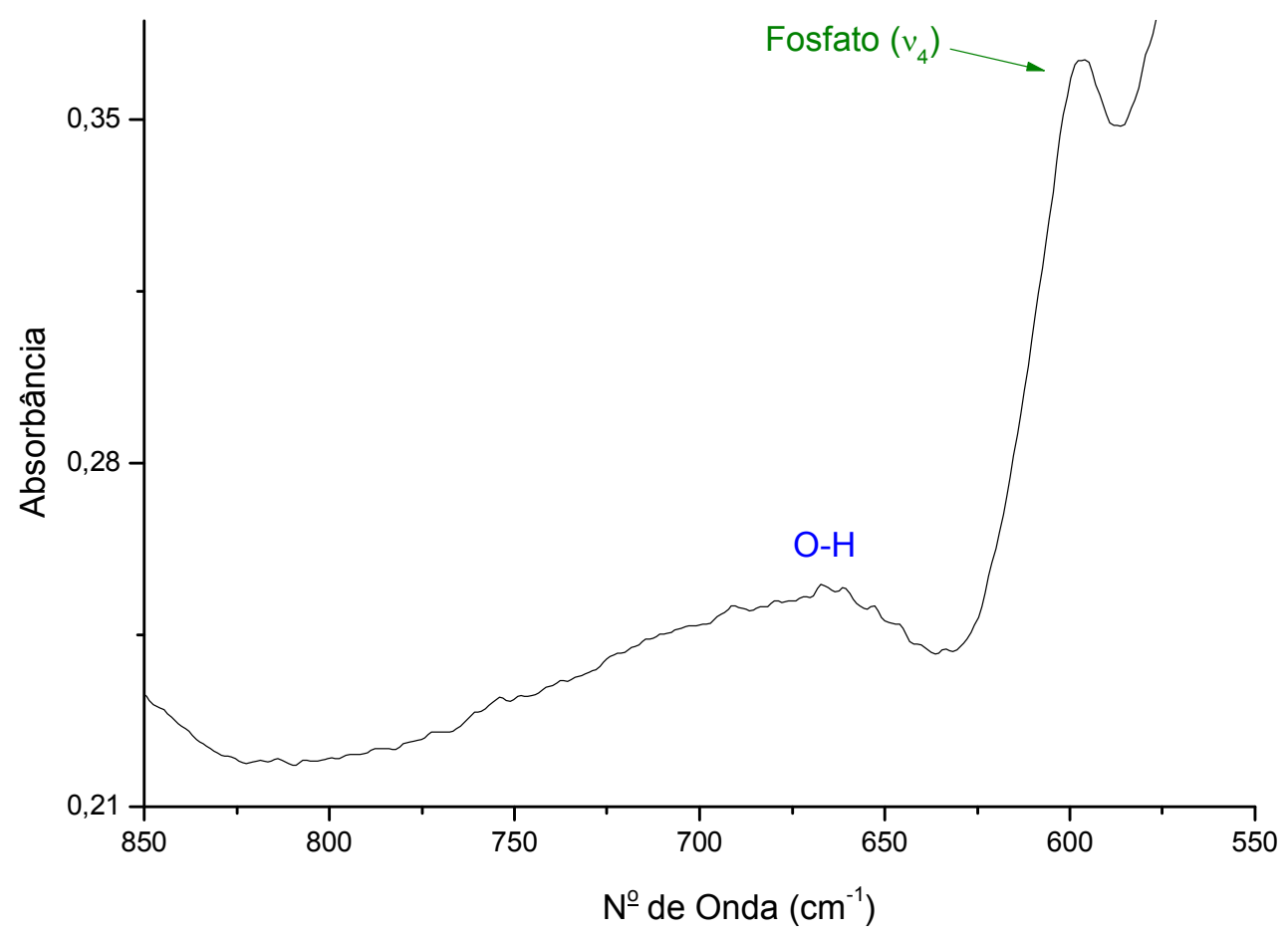

FIGURA 35 - Espectro de tíbia não irradiada na região espectral de 850 a 550 $\mathrm{cm}^{-1}$.

No total, foram identificadas 20 bandas do espectro de uma amostra de osso não irradiada, três delas correspondendo a mais de um componente: em aproximadamente $670 \mathrm{~cm}^{-1}$, correspondendo ao estiramento O-H e/ou a vibração $v_{3}$ da molécula de água; em $1640 \mathrm{~cm}^{-1}$, correspondendo amida I e a vibração $v_{2}$ da molécula de água; e em $1640 \mathrm{~cm}^{-1}$, correspondendo as bandas da amida II com a vibração $v_{3}$ do carbonato. 


\subsection{Estudo das formas de análise dos espectros}

\subsubsection{Reprodutibilidade do Espectro}

Da FIG. 36 a FIG. 38 são apresentados dois espectros obtidos para três regiões diferentes de uma mesma amostra.

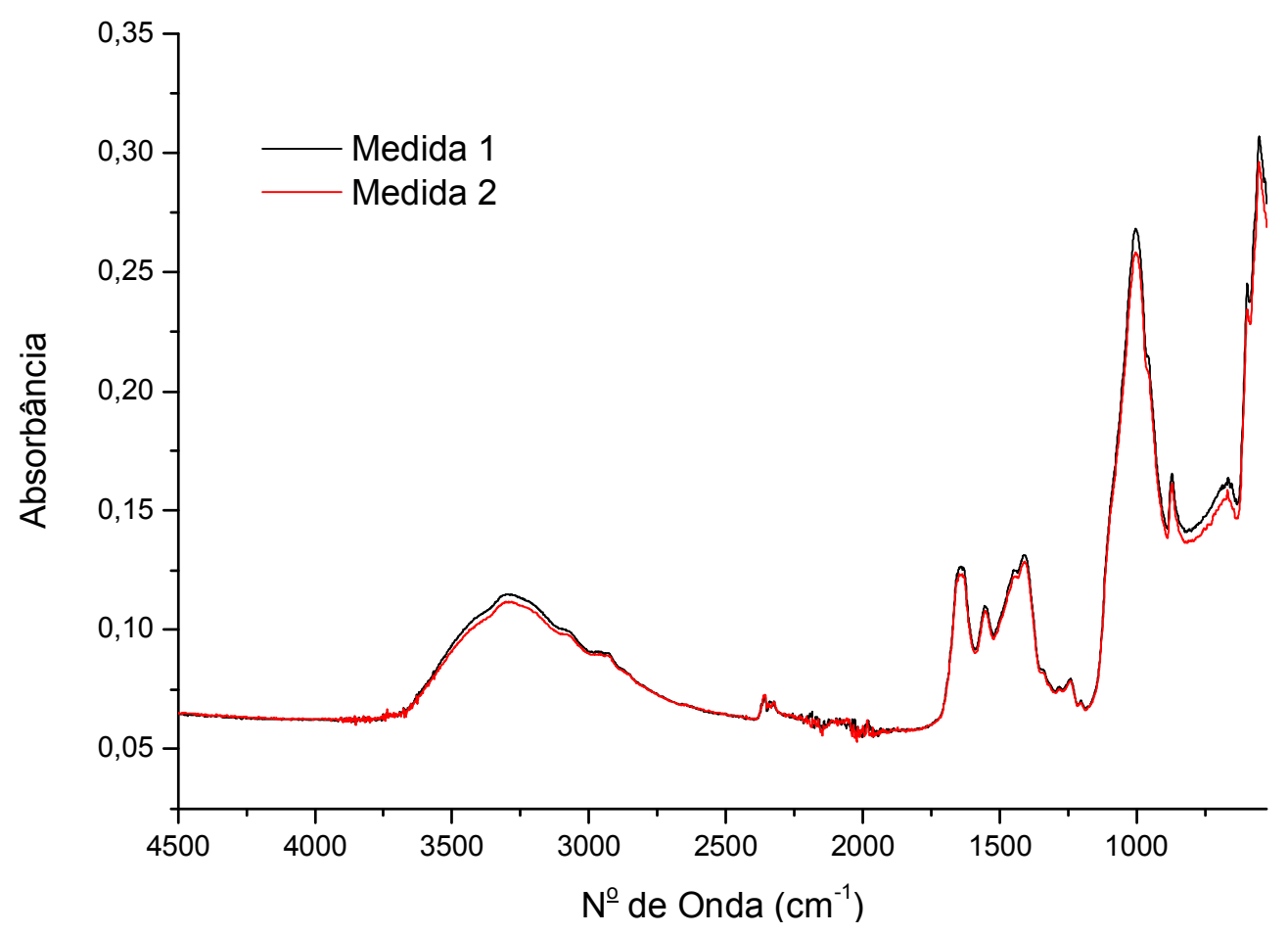

FIGURA 36 - Espectros obtidos da primeira região de análise de uma amostra

Em uma analise visual a FIG. 36 observa-se que espectros obtidos de uma mesma região apresentam exatamente o mesmo padrão, ou seja, mesmas bandas nas mesmas posições, variando pouco quanto a sua intensidade. Este comportamento se repete para as outras duas regiões analisadas, apresentadas nas FIG. 37 e FIG. 38. 


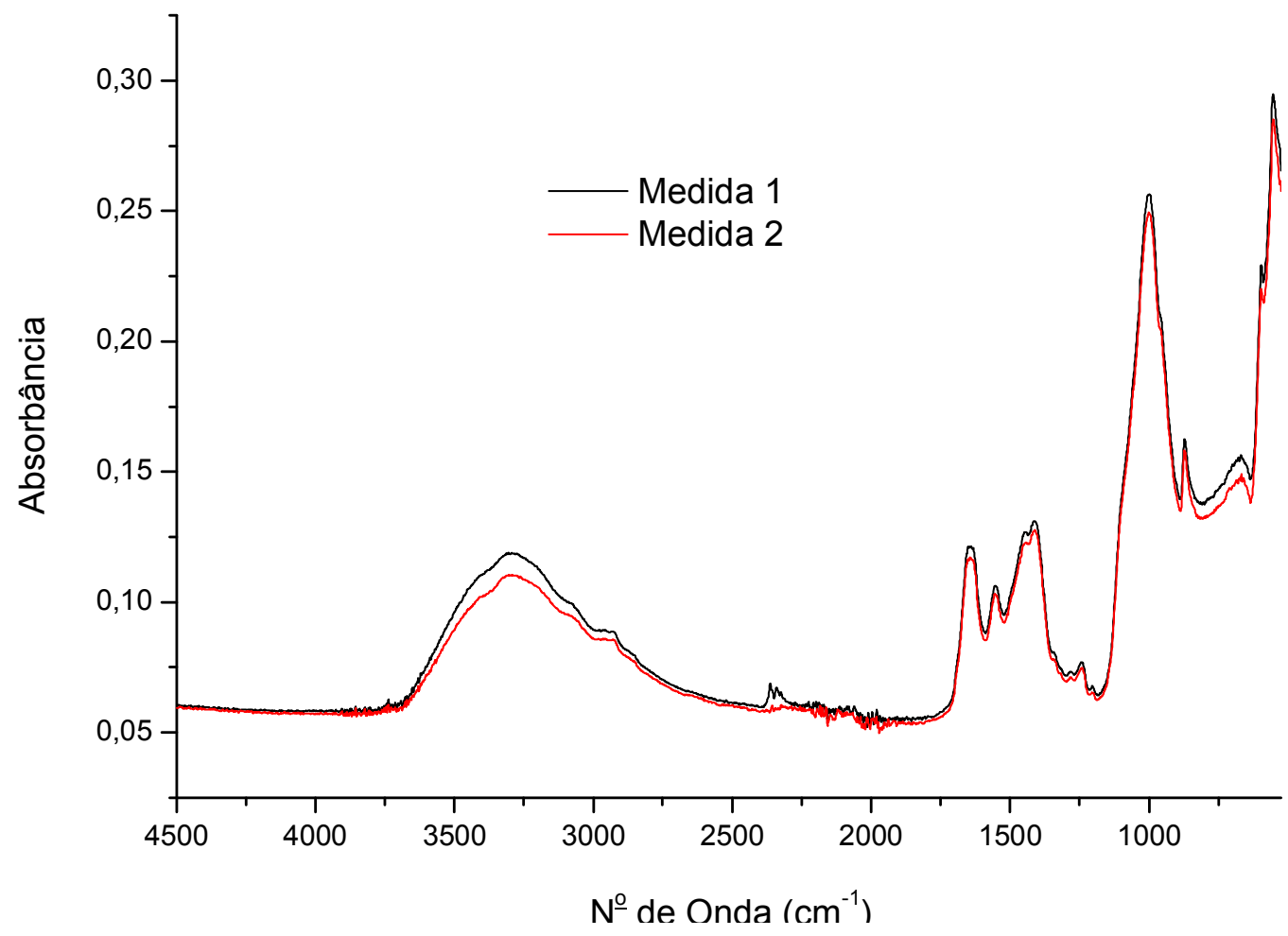

FIGURA 37 - Espectros obtidos da segunda região de análise de uma amostra

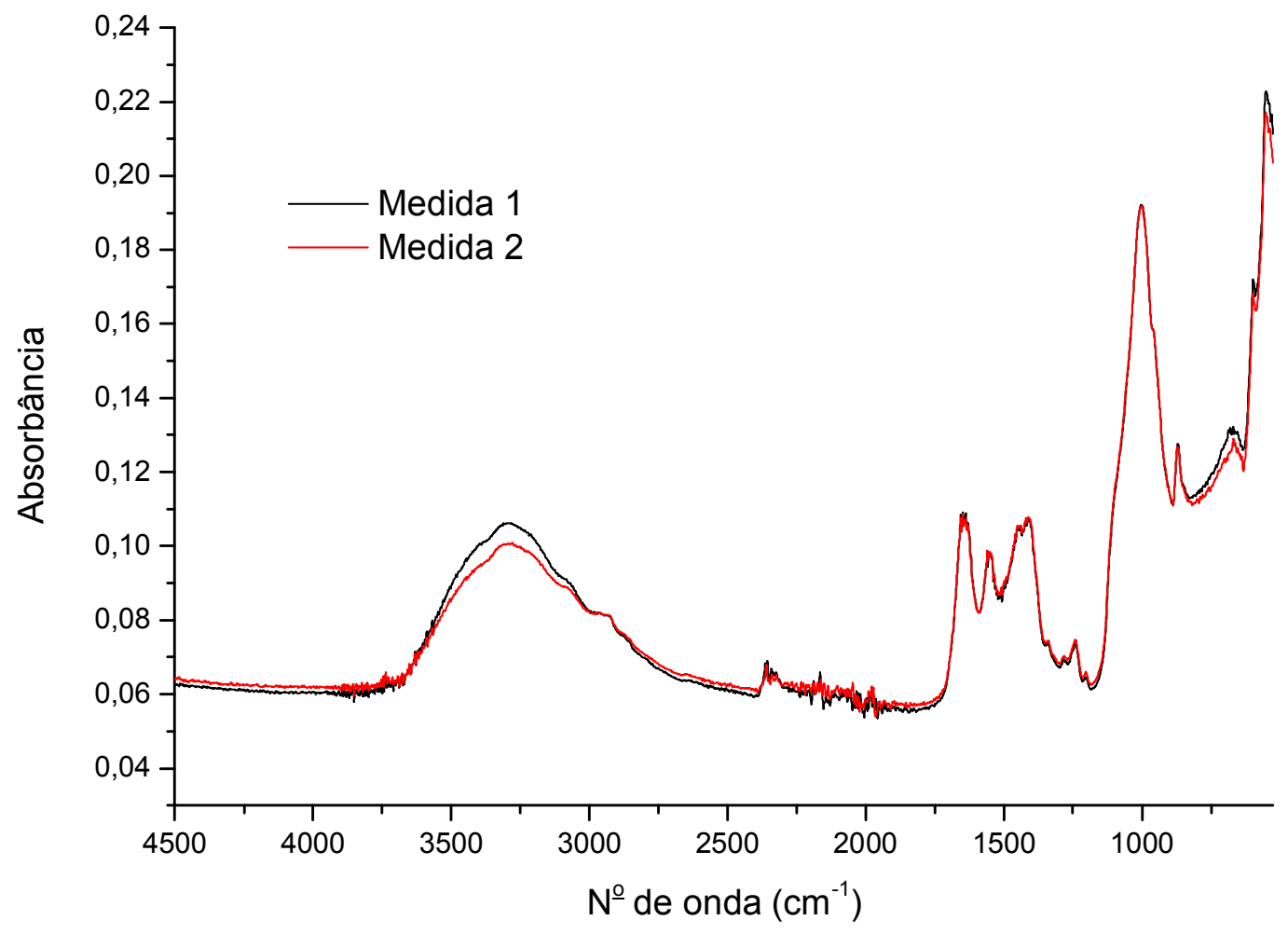

FIGURA 38 - Espectros obtidos da terceira região de análise de uma amostra 
Na FIG. 39, é apresentado um espectro de cada região sem qualquer tipo de tratamento nos dados. Nota-se que os três espectros são semelhantes quanto a posição e forma das bandas, entretanto apesar dos espectros da região 1 e 2 coincidirem quanto suas intensidades, isso não acontece para a região 3 , cujas bandas apresentam intensidade mais baixa que as bandas correspondentes da outras duas regiões.

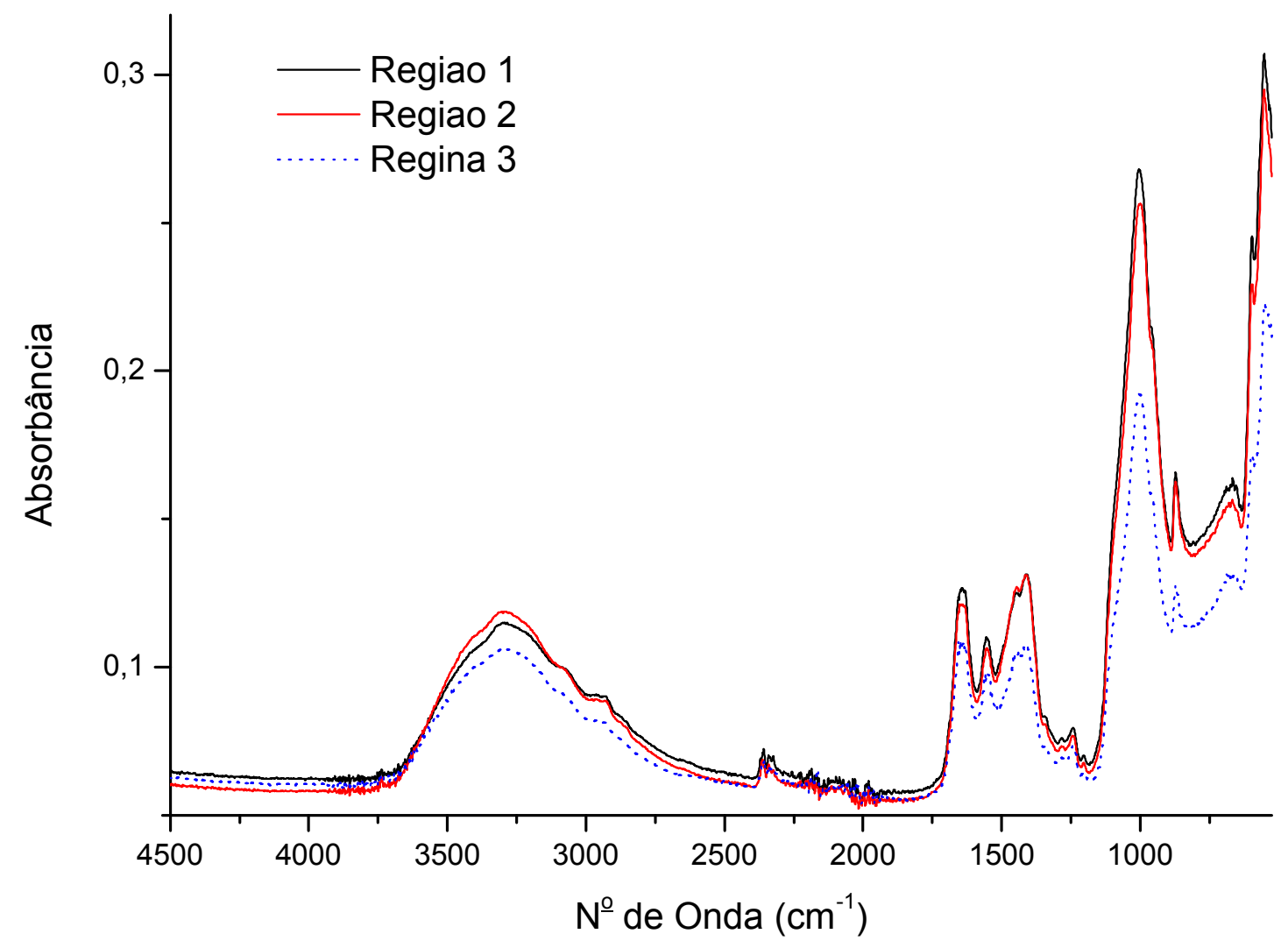

FIGURA 39 - Espectros de regiões diferentes da mesma amostra sem normalização.

Os espectros da FIG. 39 são de uma mesma amostra de osso não irradiado, entretanto, uma análise comparativa entre seus espectros nos levaria a conclusão de que a região 3 apresenta menor quantidade de componentes que as outras duas regiões, devido a diferença de intensidade. Entretanto, essa diferença não corresponde necessariamente a diferença quantitativa entre os componentes das amostras ou regiões, podendo ter sido originada pela diferença de contato da amostra com o diamante na aquisição dos espectros, ou uma diferença na superfície da amostra, ou por qualquer outro motivo que possa ter influenciada penetração do feixe na amostra, e consequentemente na intensidade do seu 
espectro. Portanto, para qualquer análise quantitativa, é necessário realizar uma correção dessa diferença de intensidade por uma normalização dos espectros.

\subsubsection{Normalização do espectro}

É possível normalizar os espectros de diversas maneiras, sendo que cada tipo de amostra exige um tipo de normalização. Para definir a melhor para amostras de osso com aproximadamente $100 \mu \mathrm{m}$ de espessura estudou-se três possíveis formas de normalização: (a) normalização pela intensidade da banda do fosfato $\left(1003 \mathrm{~cm}^{-1}\right)$, (b) pela área total dos espectros e (c) pela área sob a banda do fosfato $\left(1003 \mathrm{~cm}^{-1}\right)$.

A FIG. 40 mostra os espectros de três regiões da mesma amostra normalizados pela intensidade da banda do fosfato $\left(1003 \mathrm{~cm}^{-1}\right)$. Na FIG. 41 a região espectral de $1750 \mathrm{~cm}^{-1}$ a $1180 \mathrm{~cm}^{-1}$ dos mesmos espectros são apresentadas, para melhor visualização.

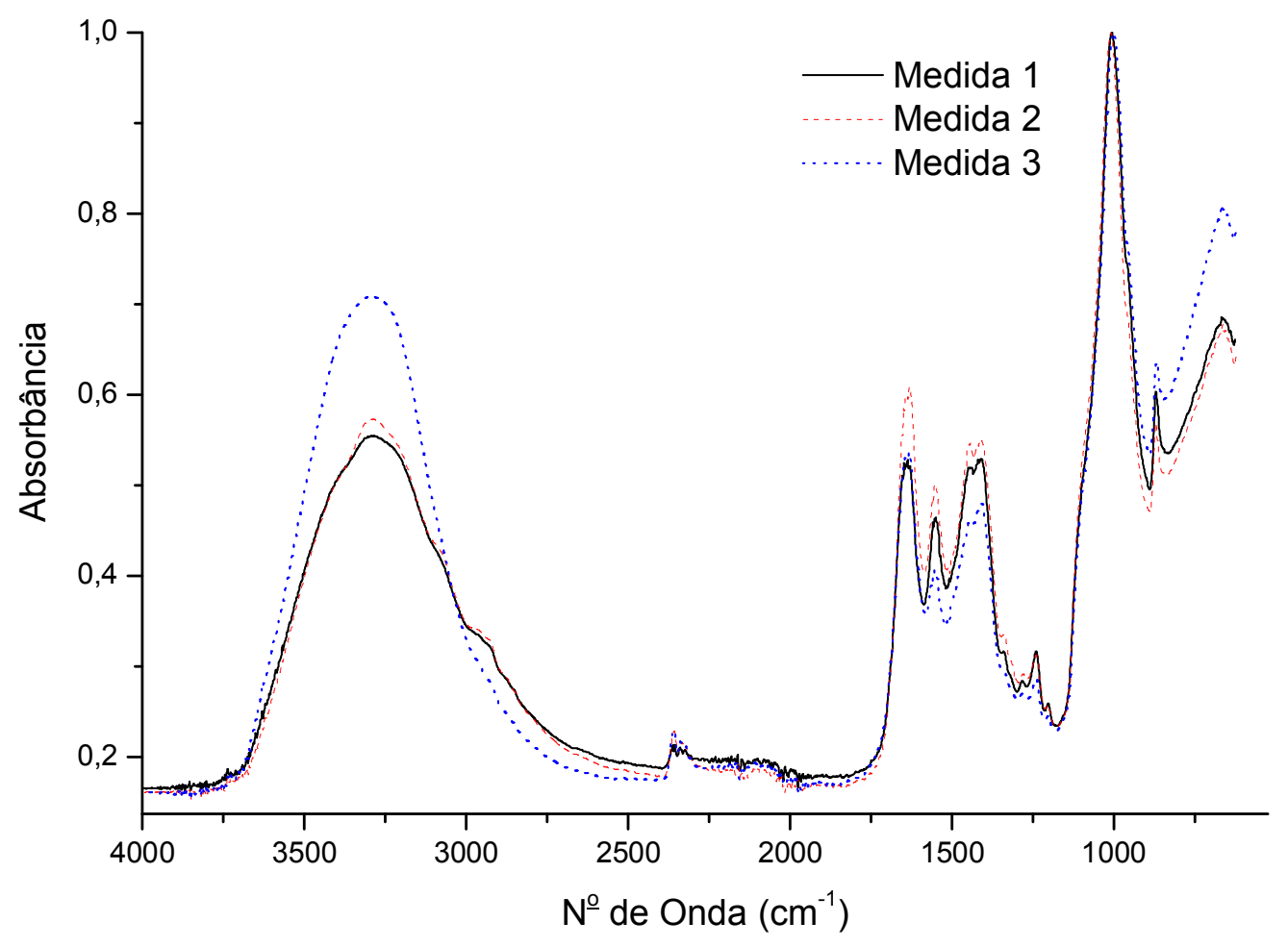

FIGURA 40 - Espectros de três regiões diferentes da mesma amostra normalizados pela intensidade da banda do fosfato. 


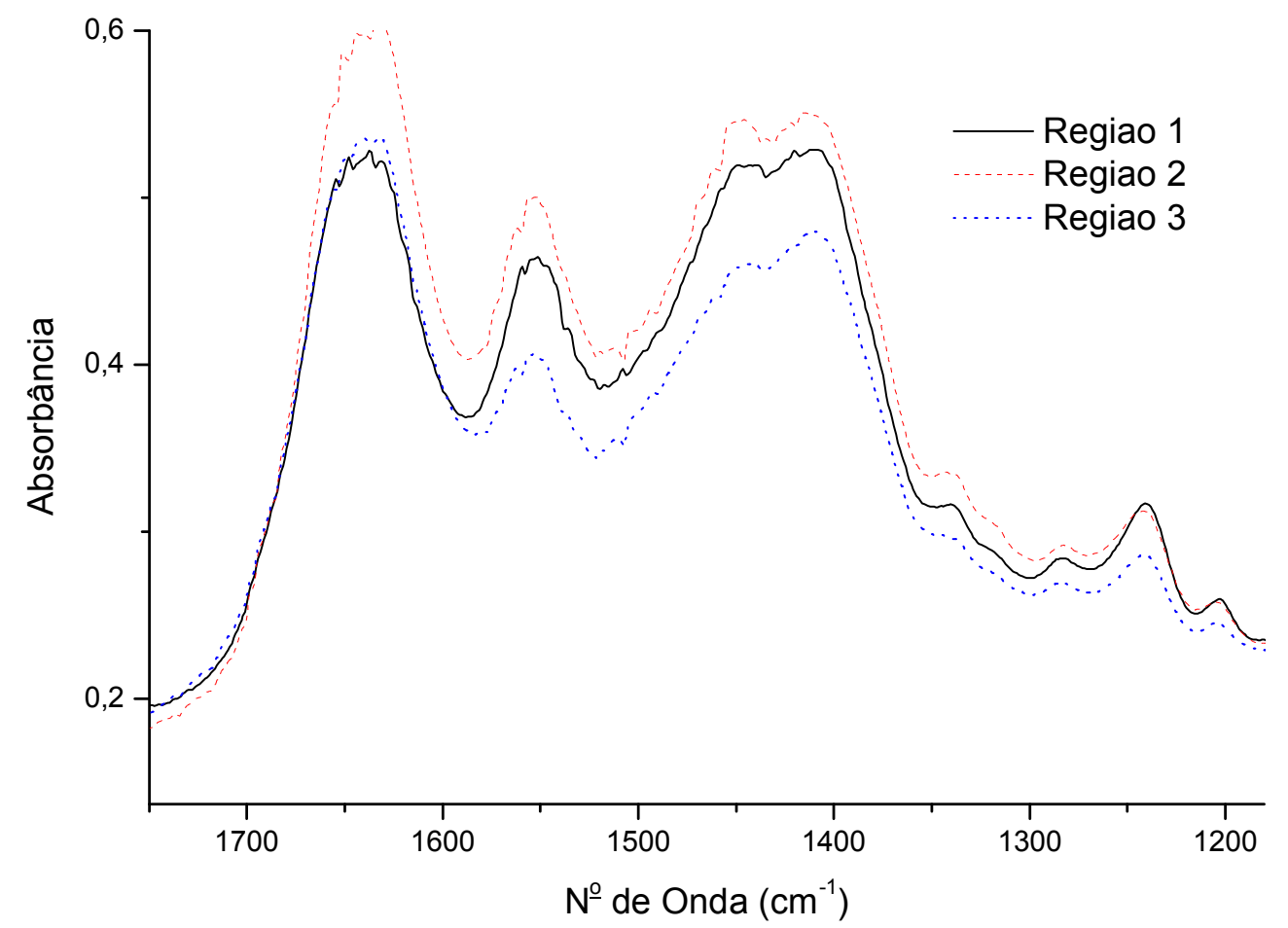

FIGURA 41 - Região espectral de $1750 \mathrm{~cm}^{-1}$ a $1180 \mathrm{~cm}^{-1}$ (amidas) dos espectros de três regiões diferentes da mesma amostra normalizados pela intensidade da banda do fosfato.

Na FIG.40 verifica-se que a normalização pela intensidade do fosfato não é adequada, não corrigindo a intensidade, isso é, não deixando-as com a mesma intensidade em todos os números de onda analisados. Este fato pode ser mais bem observado quando verificamos a área sob a região das amidas, FIG. 41.

Na FIG. 42 são apresentados os espectros de três regiões de uma amostra de osso não irradiado normalizado pela área total do espectro. Na FIG. 43 é apresenta a região espectral de $1750 \mathrm{~cm}^{-1}$ a $1180 \mathrm{~cm}^{-1}$ dos espectros da FIG. 42 . 


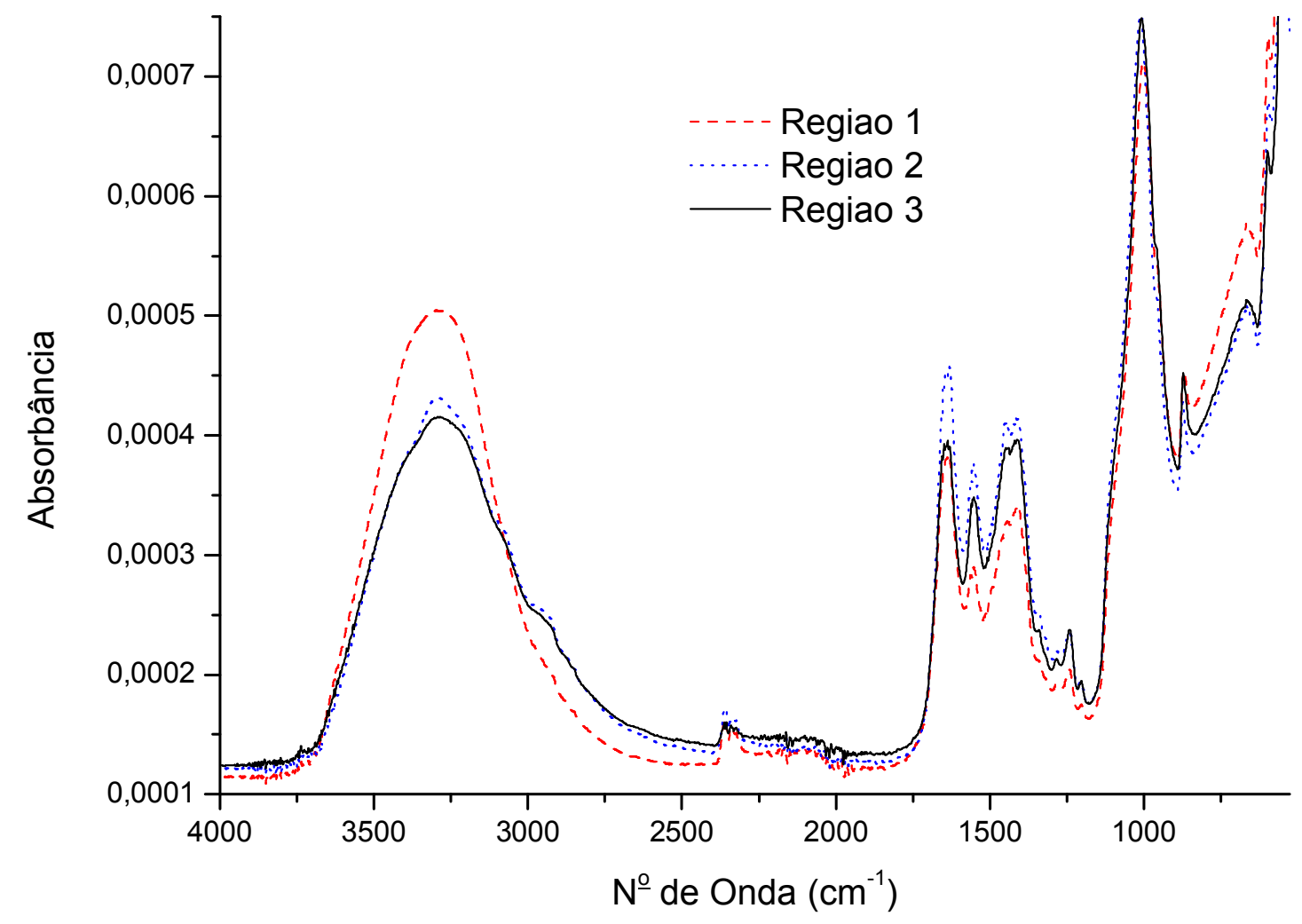

FIGURA 42 - Espectros de três regiões diferentes da mesma amostra, normalizados pela área total do espectro.

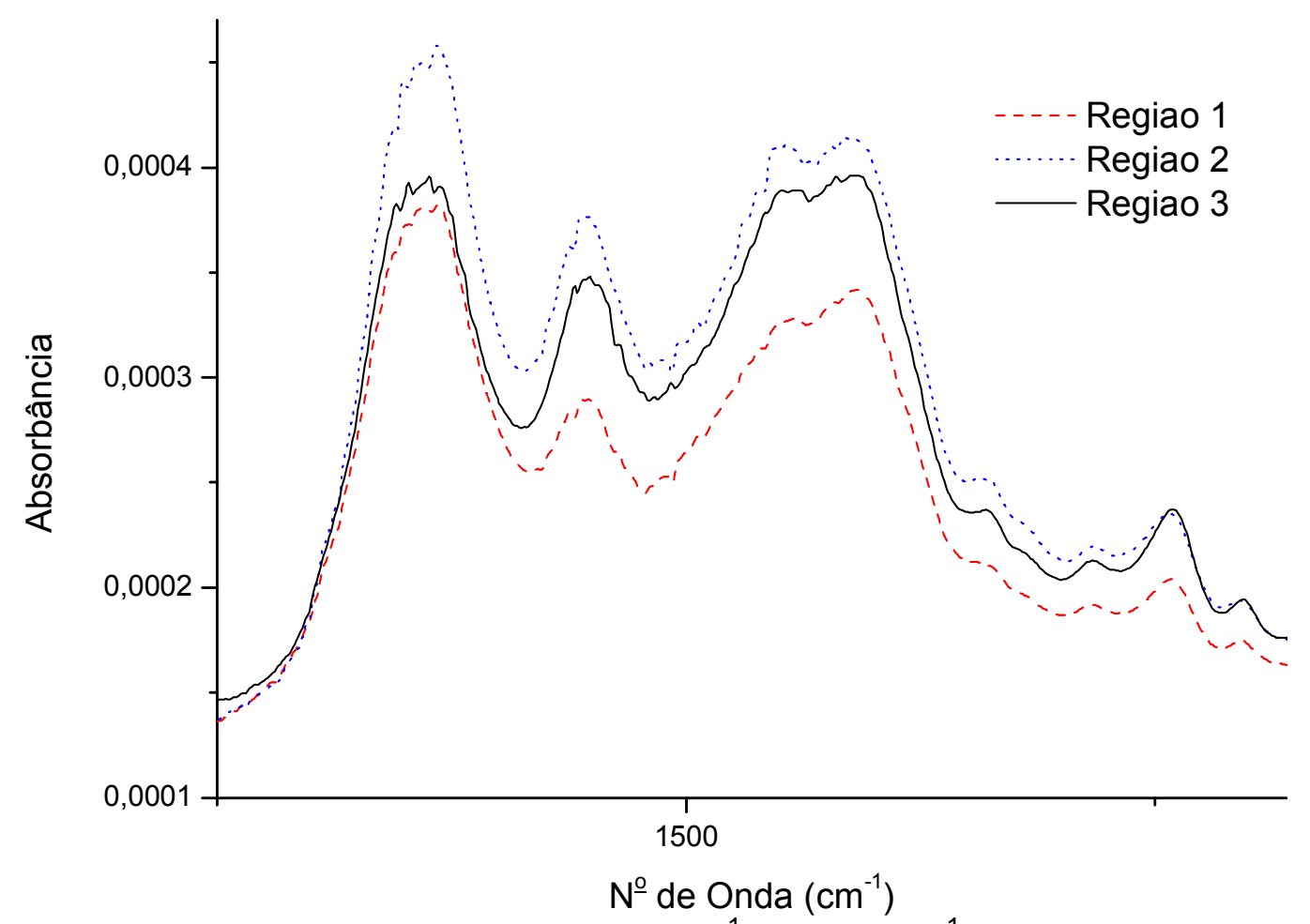

FIGURA 43 - Região espectral de $1750 \mathrm{~cm}^{-1}$ a $1180 \mathrm{~cm}^{-1}$ (amidas) dos espectros de três regiões diferentes da mesma amostra normalizados pela área total do espectro. 
Como ocorreu com a normalização pela intensidade da banda do fosfato, a normalização pela área total do espectro também não se mostrou adequada, pois não corrigiu as intensidades das bandas como pode ser visto nas FIG. 42 e FIG 43.

A FIG. 44 mostra os espectros de três regiões da mesma amostra normalizados pela área sob a banda do fosfato $\left(1003 \mathrm{~cm}^{-1}\right)$, sendo a região espectral de $1750 \mathrm{~cm}^{-1}$ a $1180 \mathrm{~cm}^{-1}$ dos mesmos espectros apresentados na FIG. 41.

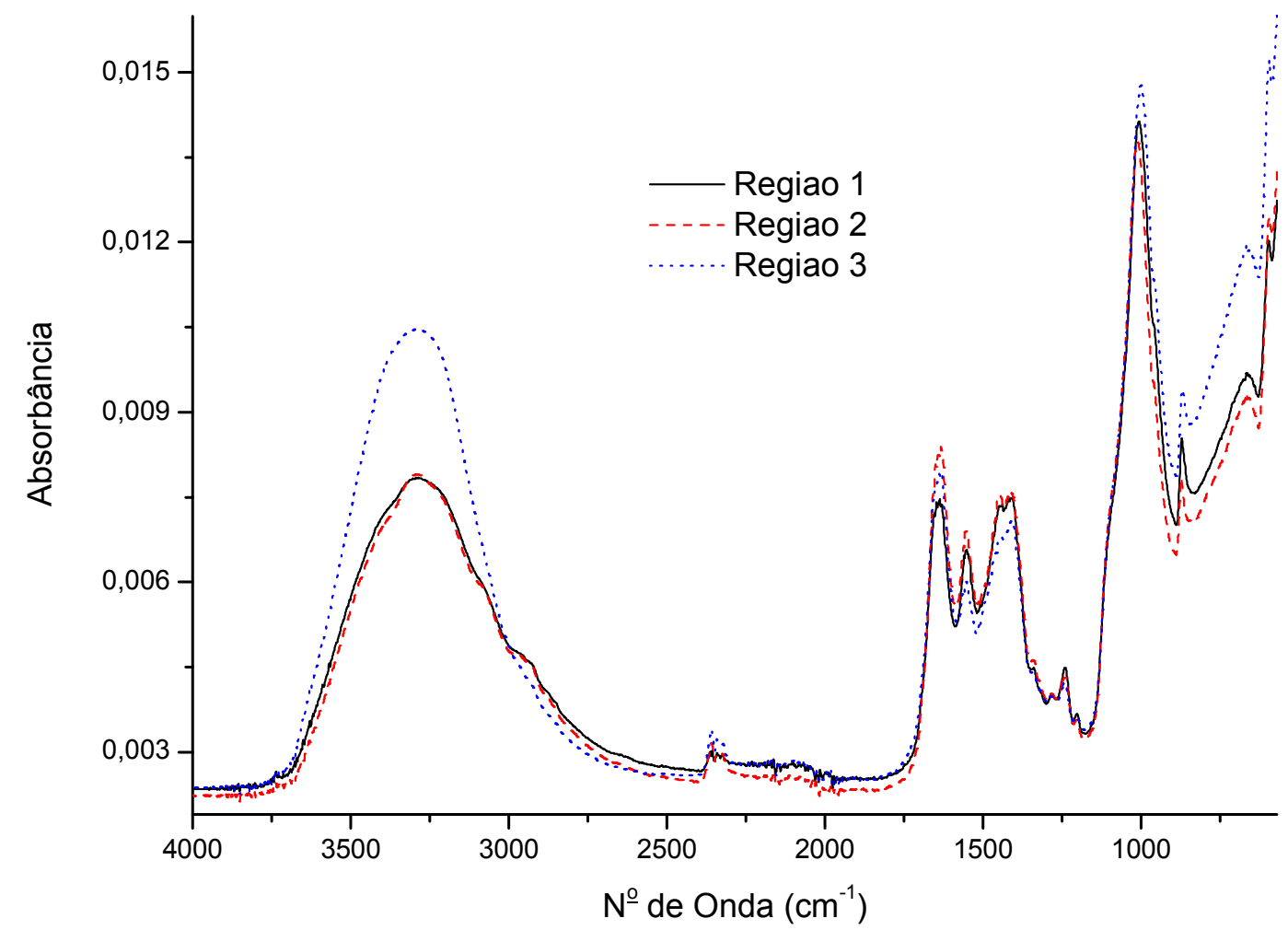

FIGURA 44 - Espectros de três regiões diferentes da mesma amostra normalizados pela área sob a banda do fosfato. 


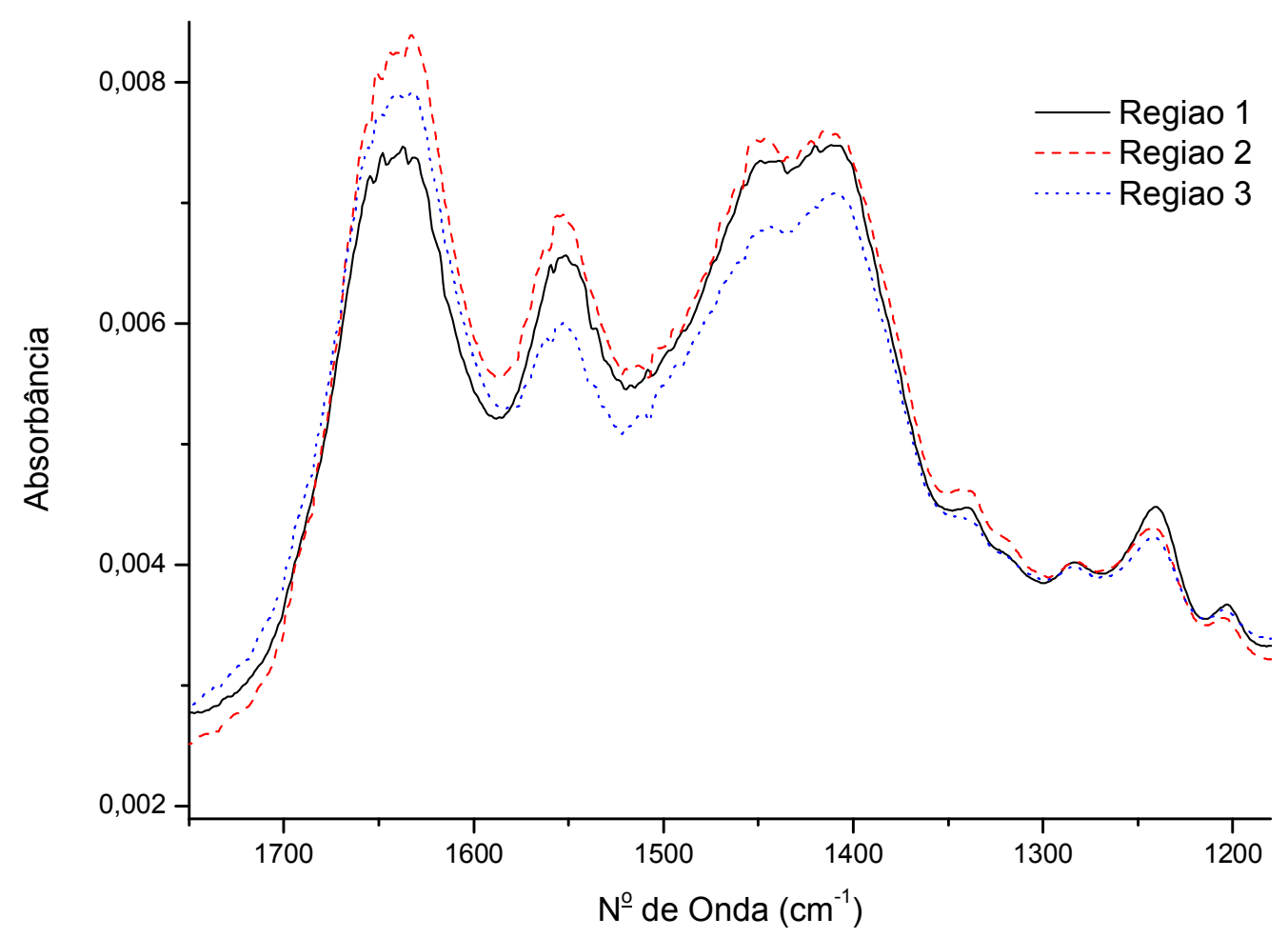

FIGURA 45 - Região espectral de $1750 \mathrm{~cm}^{-1}$ a $1180 \mathrm{~cm}^{-1}$ (amidas) dos espectros de três regiões diferentes da mesma amostra normalizados pela área total do espectro.

Como os dois métodos de normalização testados anteriormente, a normalização pela área sob a banda do fosfato também não teve sucesso em corrigir a diferenças entre as intensidades das bandas, como pode ser visto nas FIG. 44 e FIG 45.

Comparando os métodos de normalização verifica-se que teve sucesso em corrigir as intensidades dos espectros como um todo, e portanto, não foi possível realizar uma analise quantitativa pela comparação direta entre os espectros, sendo que, por uma comparação direta, as únicas características que se pode comparar são a largura, posição e forma das bandas.

Para podermos realizar uma analise semi-quantitativa, a área de cada banda será calculada para cada espectro. A área sob a banda corresponde a quantidade do componente ao qual ela se refere na amostra. Cada componente terá sua área sob a banda normalizada pela área obtida da banda de um outro componente específico, do mesmo espectro, que não sofre alteração com o tratamento realizado nas amostras. Como foram estudados os efeitos a irradiação 
com o laser de Er,Cr:YSGG (que promove aumento de temperatura na amostra), a normalização foi feita utilizando-se a área sob abanda do fosfato, pois este é o componente do osso mais estável quando ocorre aumento de temperatura ${ }^{59,60}$.

\subsubsection{Determinação da posição das bandas}

Para verificar a aplicabilidade do método da segunda derivada na identificação das posições das bandas do espectro, foi calcula a segunda derivada do espectro de uma amostra de osso não irradiado, apresentada na FIG.46.

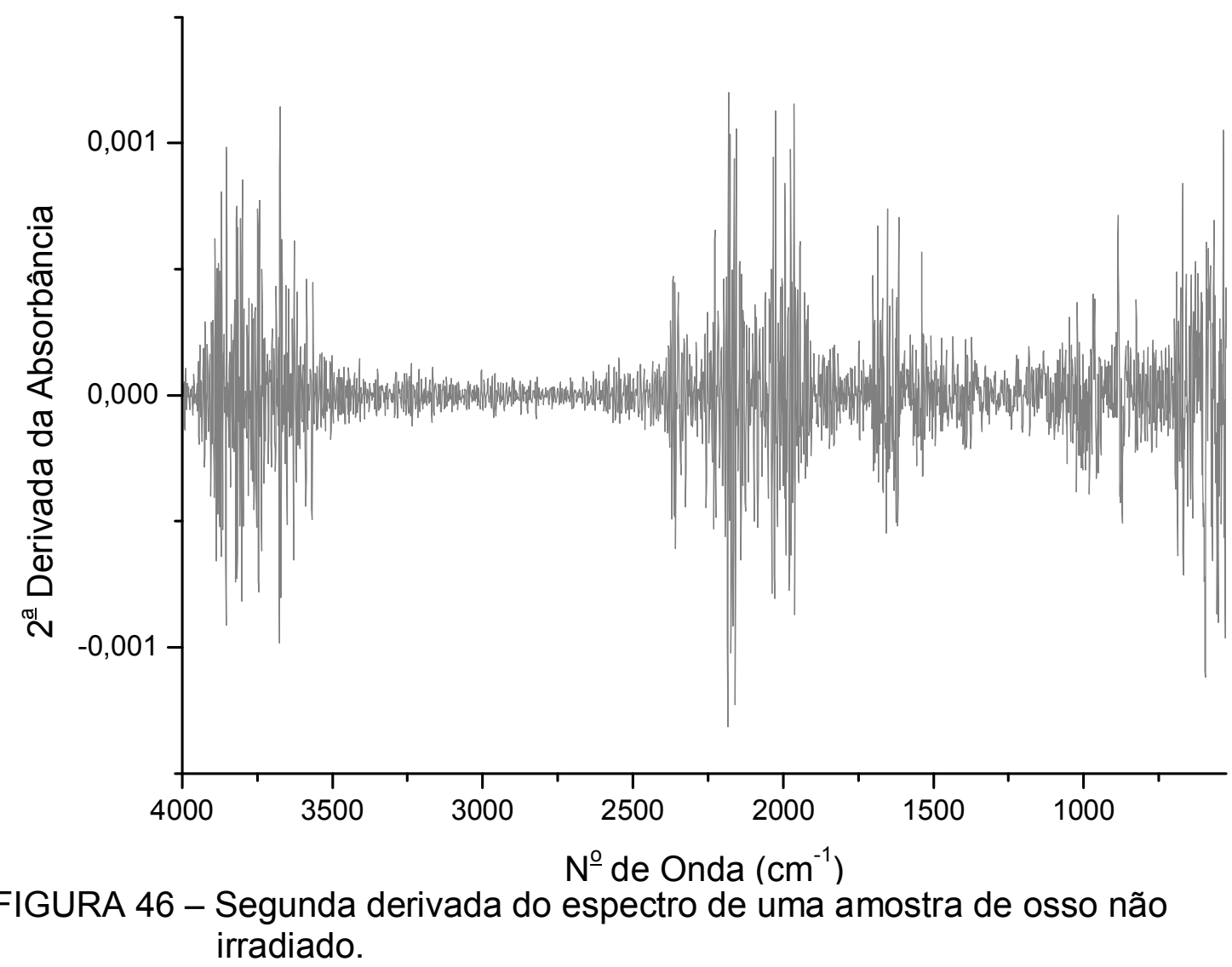

Na FIG. 46 observa-se que o resultado da segunda derivada do espectro de absorbância é bastante ruidoso, não sendo fácil identificar a posição das bandas. Para tentar facilitar na identificação das bandas na FIG. 47 é apresentada a região espectral de $1750 \mathrm{~cm}^{-1}$ a $1180 \mathrm{~cm}^{-1}$, correspondente a região das amidas, do gráfico da segunda derivada. 


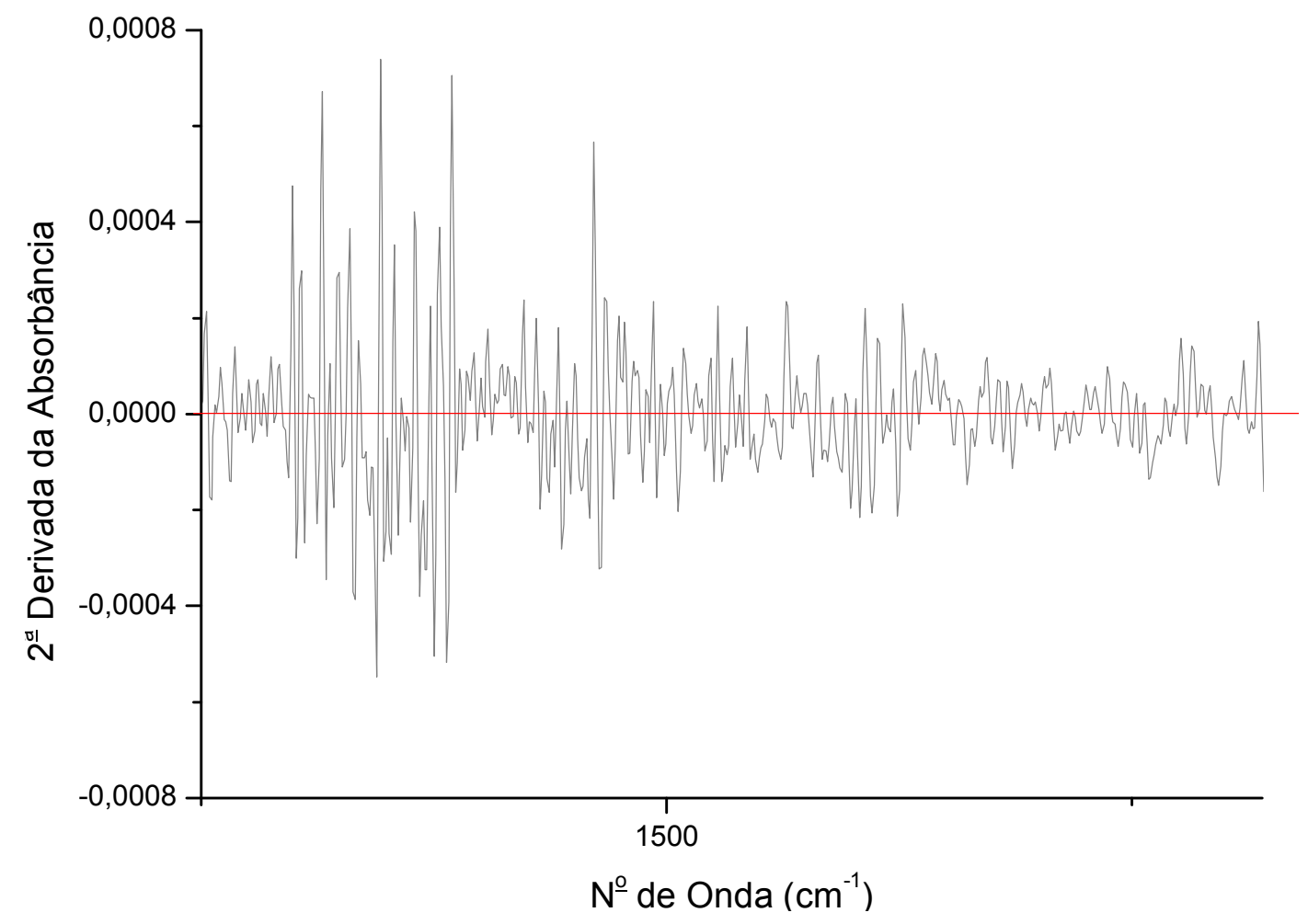

FIGURA 47 - Região espectral de $1750 \mathrm{~cm}^{-1}$ a $1180 \mathrm{~cm}^{-1}$ da segunda derivada do espectro de uma amostra de osso não irradiado.

Mesmo restringindo a segunda derivada à região espectral de $1750 \mathrm{~cm}^{-1}$ a $1180 \mathrm{~cm}^{-1}$, não foi possível identificar a posição das bandas, pois não consegue se diferenciar banda e de ruído. Portanto, não é possível utilizar o método da segunda derivada para localizar as bandas dos espectros de ossos obtidos neste trabalho, e portanto foi utilizado o método convencional de buscar a posição central da banda no próprio espectro.

\subsubsection{Calculo da área sob as bandas}

A FIG.48 apresentada os ajustes de gaussianas as bandas em diferentes regiões espectrais. Como anteriormente explicado, nesta técnica, tenta-se encontrar as Gaussianas (em verde), cujas sobreposições (em vermelho) melhor descrevem a linha do espectro. 
(A)

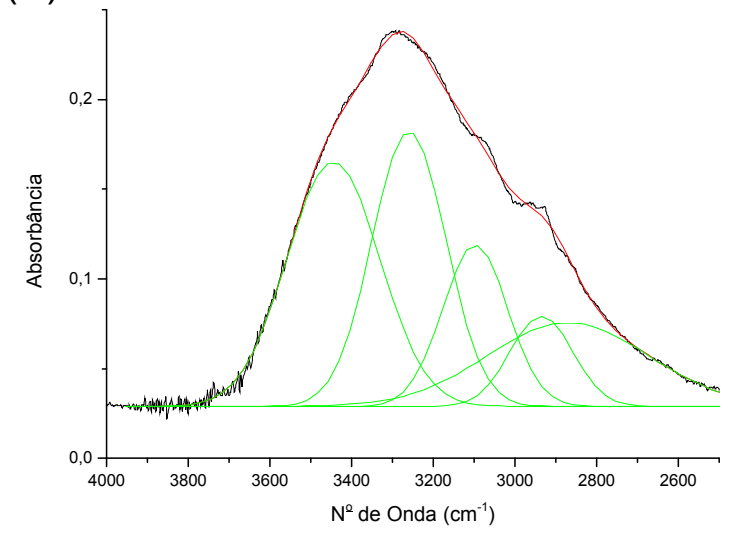

(C)

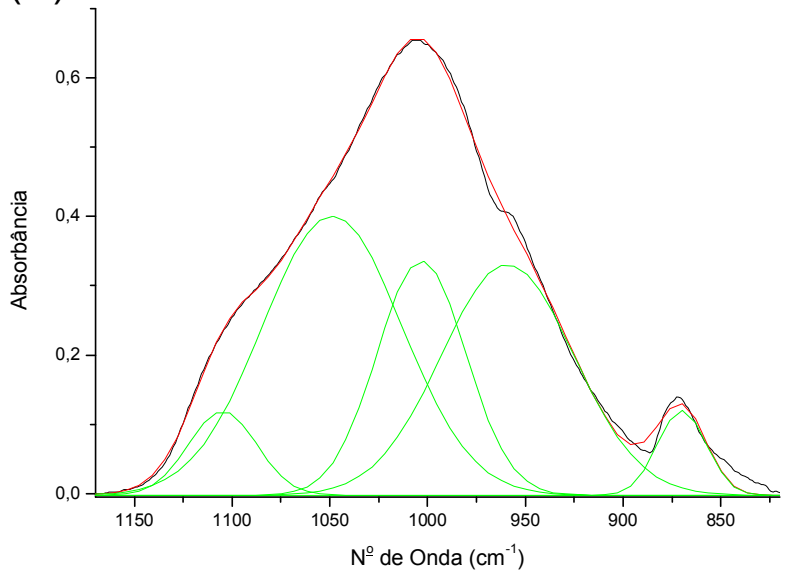

(B)

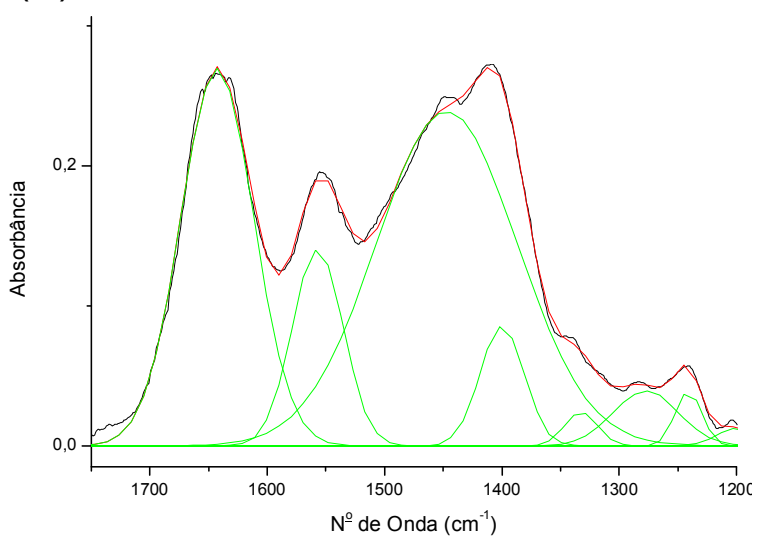

(D)

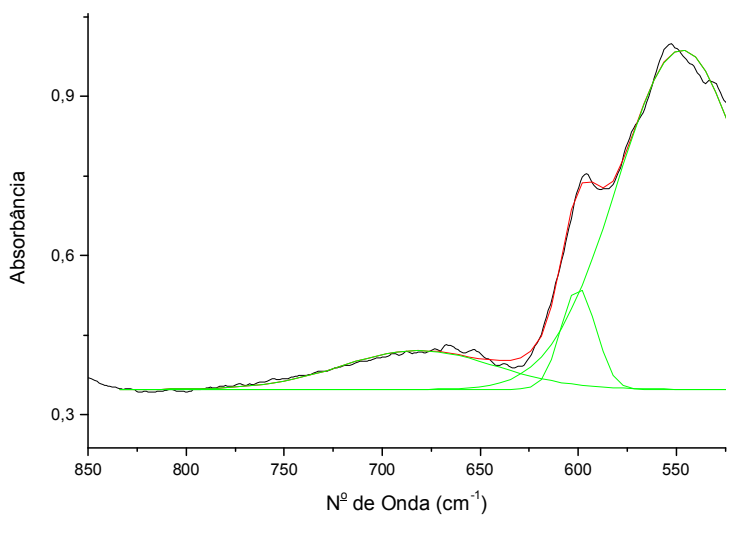

FIGURA 48 - Ajuste de Gaussiana as bandas em diferentes regiões espectrais: (A) $4000-2500 \mathrm{~cm}^{-1}$; (B) $1700-1180 \mathrm{~cm}^{-1}$; (C) $1180-800 \mathrm{~cm}^{-1}$; (D) $850-550 \mathrm{~cm}^{-1}$.

Apesar de o ajuste gaussiano ser um método onde supostamente é considerada toda área sob a banda, ele não é totalmente confiável visto que os parâmetros da gaussiana são controlados pelo operador do programa. Outra desvantagem e que em algumas bandas estão sobrepostos mais modos de vibração do que é possível identificar. Um exemplo disso ocorre com a banda do fosfato na região espectral de $1152-890 \mathrm{~cm}^{-1}$. A literatura reporta que existem cinco bandas de vibração do fosfato sobrepostas nesta região, entretanto, observando o espectro obtido (FIG 48C) só é possível identificar no máximo quatro bandas, ou seja, a quinta banda tem sua área totalmente sobreposta as demais bandas e por isso não é possível ajustar uma curva gaussiana a ela.

Com esse fato, a grande vantagem do método é perdida, já que não é possível se obter a área real da banda. Esse problema poderia ser contornado 
utilizando-se o método da segunda deriva na localização das bandas, entretanto, como visto anteriormente, não é possível a utilização deste método para os espectros obtidos.

A outra técnica utilizada é apresentada na FIG. 49: primeiro traça-se o linha de base (baseline) nas bandas cujas áreas serão calculadas (FIG. 49A); subtraise a baseline, para as bandas passarem a ter base no zero (FIG. 49B); depois basta integrar as bandas para obter sua área.

(A)

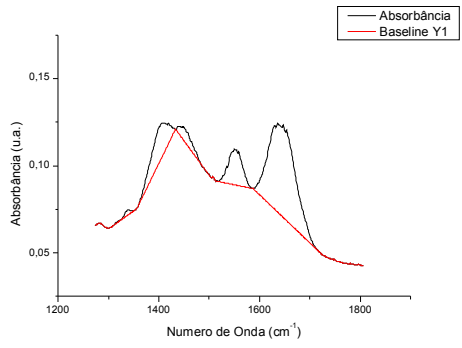

(B)

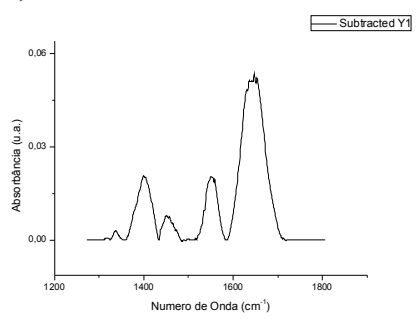

(C)

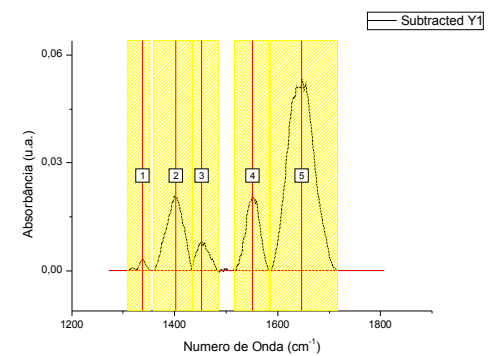

FIGURA 49 - Cálculo das áreas pelo método de integração direta.

Com este método não é calculado o valor real da área sob a banda, visto que a região onde as bandas se sobrepõem é desprezada, e, portanto uma parcela da área sob a banda não é utilizada. Entretanto para uma analise semiquantitativa, com áreas normalizadas o resultado é satisfatório.

\subsection{Amostras irradiadas}

Para comparar os espectros dos diferentes grupos de análise quanto a forma e posição das bandas os espectros de uma amostra de cada grupo foram sobrepostos em mesmo gráfico (FIG. 50). Optou-se em não colocar os espectros de todas as amostras em um mesmo gráfico, pois isso dificultaria a visualização, já que seriam 18. As amostras para este caso foram escolhidas aleatoriamente. 


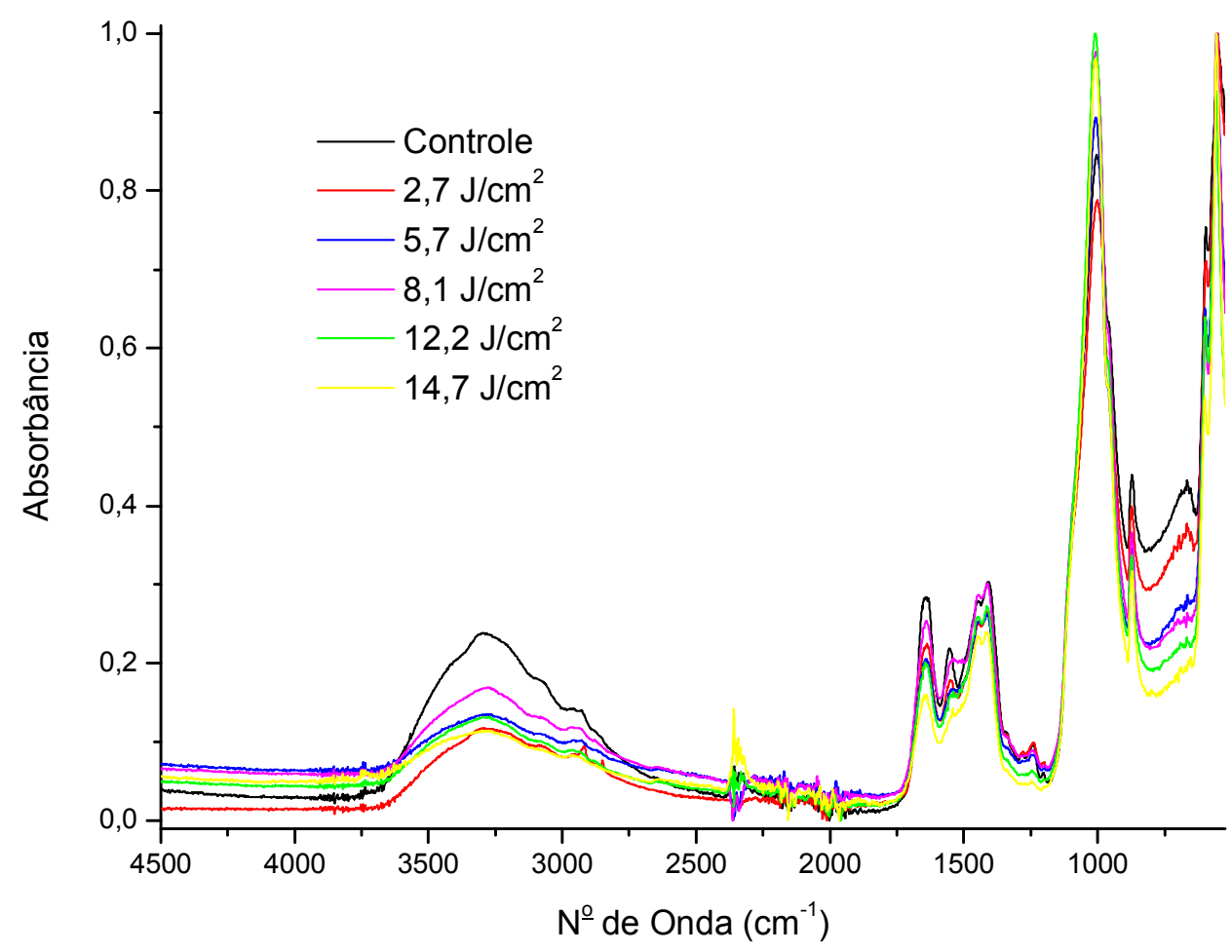

FIGURA 50 - Espectros de uma amostra de cada grupo de estudo escolhidas aleatoriamente.

Foi possível identificar todas as bandas pretendidas em todos os grupos estudados, não sendo encontrada nenhuma nova banda, que indicaria a formação de compostos ou mudanças bruscas nos modos de vibração.

Para facilitar a exposição dos resultados, a análise dos espectros foi feita separadamente para cinco regiões espectrais: de $4000 \mathrm{~cm}^{-1}$ a $2500 \mathrm{~cm}^{-1}$; de $1750 \mathrm{~cm}^{-1}$ a $1250 \mathrm{~cm}^{-1}$; de $1300 \mathrm{~cm}^{-1}$ a $1180 \mathrm{~cm}^{-1} ; 1300 \mathrm{~cm}^{-1}$ a $1180 \mathrm{~cm}^{-1}$; e de $850 \mathrm{~cm}^{-1}$ a $550 \mathrm{~cm}^{-1}$.

\subsubsection{Região espectral de $4000 \mathrm{~cm}^{-1}$ a $2500 \mathrm{~cm}^{-1}$}

A FIG. 51, referente a região espectral de $4000-2500 \mathrm{~cm}^{-1}$ evidencia as bandas da água, do estiramento $\mathrm{O}-\mathrm{H}$ e as bandas de $\mathrm{C}-\mathrm{H}$ sobrepostas. As bandas relativas aos grupos irradiados com maior densidade de energia apresentam menor intensidade, entretanto esse fato por si só não indica uma perda de água com a irradiação, visto que as bandas não estão normalizadas. Ela 
pode ter ocorrido devido as diferenças entre as amostras ou à pressão exercida sobre estas no momento da coleta dos espectros.

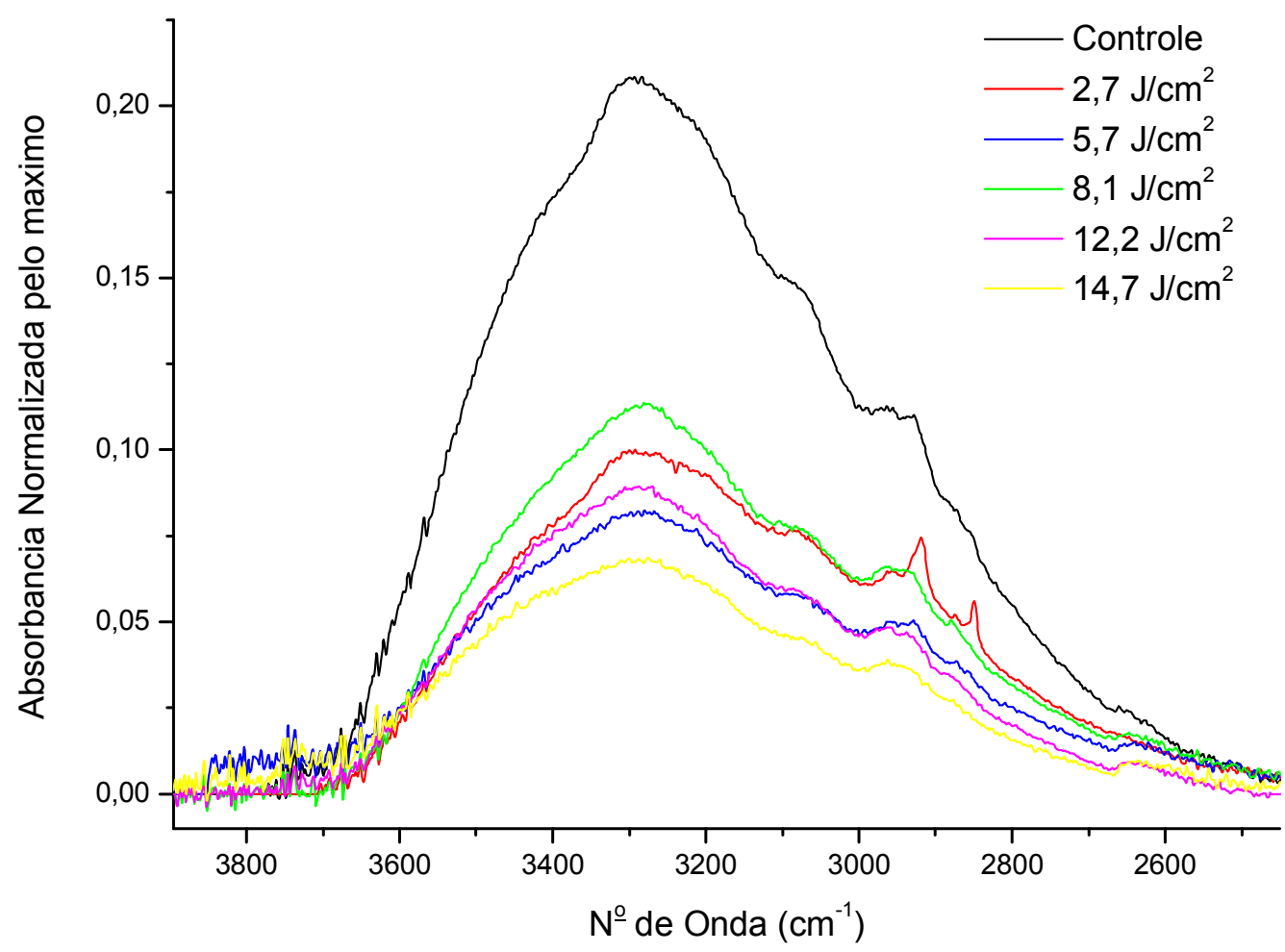

FIGURA 51 - Região espectral de 4000 a $2500 \mathrm{~cm}^{-1}$ de uma amostra de cada um dos grupos analisados.

Uma mudança gradativa com o aumento de densidade de energia com a qual a amostra foi irradiada e que indica uma alteração, mesmo sem a normalização pela banda do fosfato, são o achatamento da banda e a perda do 'ombro' do lado esquerdo (vibração $v_{2}$ da água). Essa mudança indica uma perda de água do material com a irradiação. Não foi observada nenhuma mudança expressiva na largura nem na posição desta banda de água.

A FIG. 52 apresenta o gráfico da área normalizada sob a banda da região espectral de $4000 \mathrm{~cm}^{-1}$ a $2500 \mathrm{~cm}^{-1}$ em função da fluência de energia utilizada na irradiação. Nesta região, dada a dificuldade em separar as sobreposições, uma única banda foi considerada, e seu conteúdo foi relacionado com o da água presente na amostra, pois nesta região espectral, a água é o componente presente em maior quantidade no tecido ósseo. Alguns dados parecem não 
apresentar barra de erro, pois o erro não é visível considerando a escala do gráfico, estando embutido no tamanho do ponto.

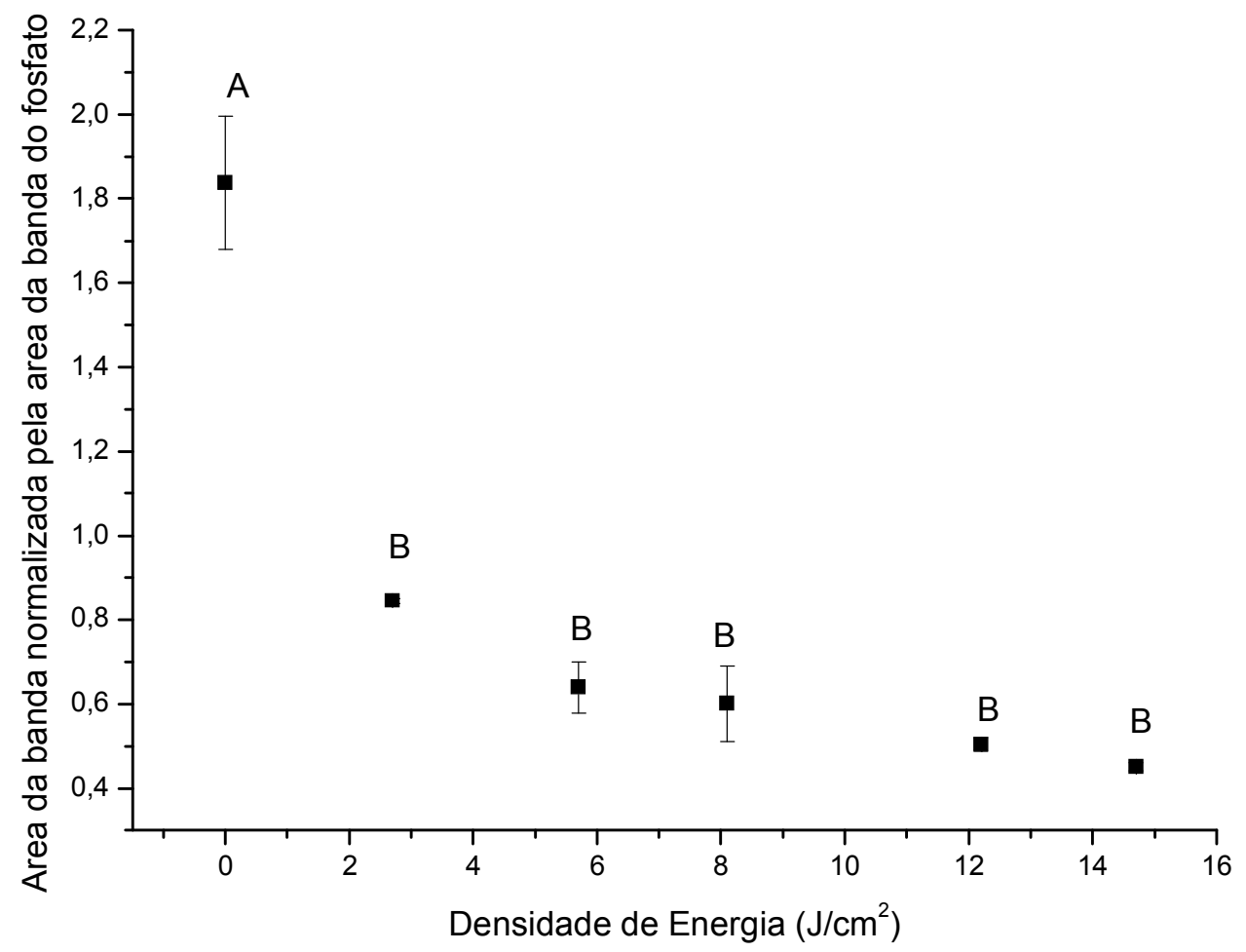

FIGURA 52- Área sob a banda da água normalizada pela área da banda do fosfato em função da densidade de energia utilizada na irradiação. Letras diferentes representam dados significativamente diferentes; e letras iguais dados que não apresentam diferença estatística.

Pela estatística utilizada, teste ANOVA/Tukey com nível de significância de 0,05, ocorreu diferença estatística entre o grupo das amostras não irradiadas em relação a todos os grupos com amostras irradiadas, essa diferença é representa pelas letras sobre os dados: letras diferentes representam dados significativamente diferentes; letras iguais dados não significativamente diferentes. Os grupos das amostras irradiadas com diferentes densidades de energia não apresentaram diferenças estatísticas entre si, entretanto, na FIG. 52, é possível observar uma tendência de queda na quantidade de água com o aumento da densidade de energia utilizada. 


\subsubsection{Região espectral de $1750 \mathrm{~cm}^{-1}$ a $1250 \mathrm{~cm}^{-1}$}

A FIG. 53 apresenta os espectros de diferentes grupos na região espectral de 1750-1250 $\mathrm{cm}^{-1}$, onde são encontradas bandas de absorção das amidas I e II, água, carbonato, e colágeno.

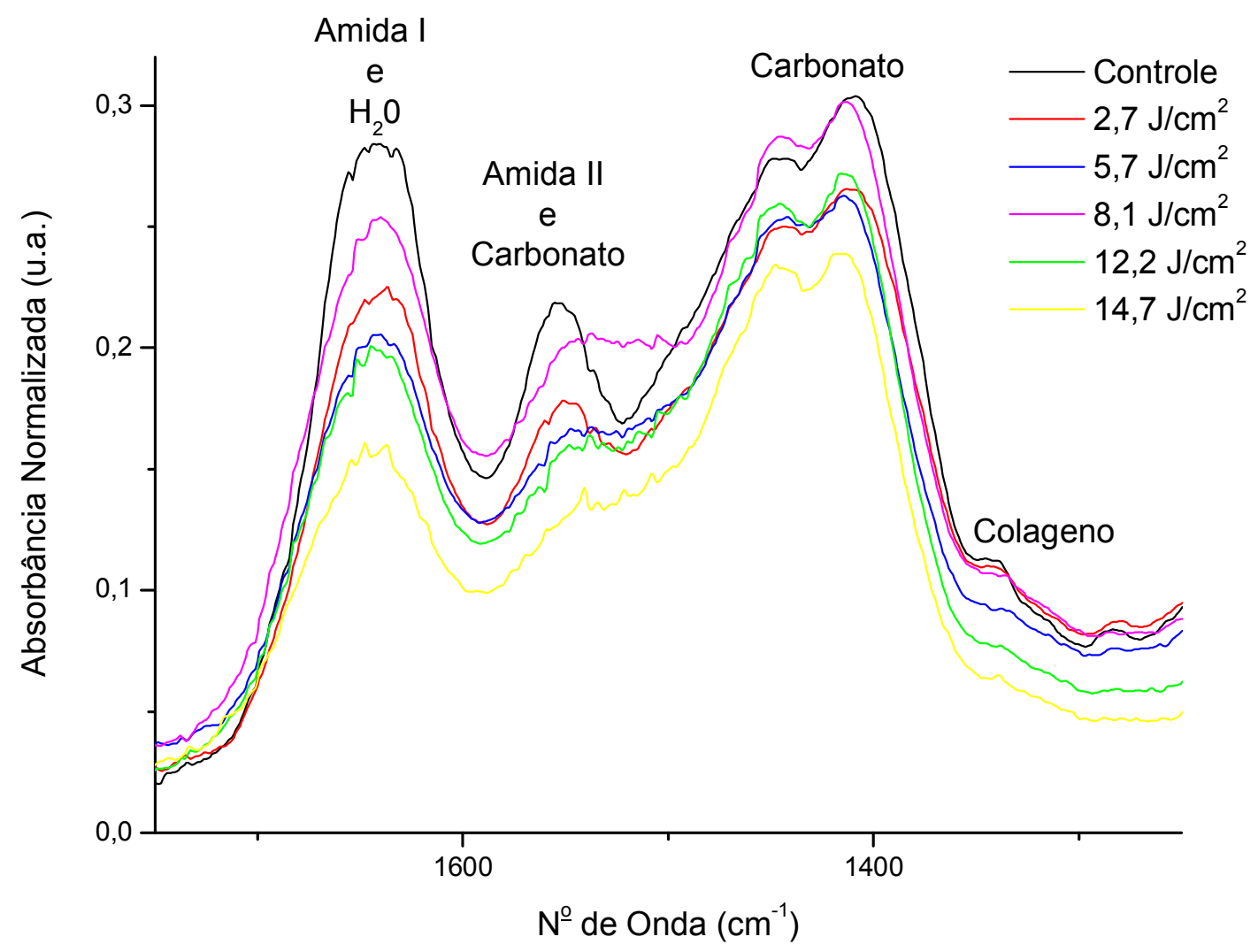

FIGURA 53 - Região espectral de 1750 a $1250 \mathrm{~cm}^{-1}$ de uma amostra de cada um dos grupos analisados.

Não é possível afirmar a respeito da intensidade, já que as bandas não estão normalizadas, entretanto é notável a deformação das bandas correspondentes ao colágeno e a sobreposição da Amida II e Carbonato, indicando a perda destes componentes com a irradiação. É possível sugerir que esta perda é maior quanto maior a densidade de energia utilizada na irradiação, visto que a deformação da banda é gradativa com o aumento da densidade de energia. 
Quanto a posição e largura das bandas, com exceção da banda correspondente a Amida II e Carbonato, não houve nenhuma variação. A banda correspondente da Amida II e Carbonato alargam com o aumento da densidade de energia, entretanto este efeito pode ser devido a diminuição da área da banda, uma vez que ela está sobreposta a outras bandas, que são evidenciadas com o seu desaparecimento.

As FIG.54, FIG. 55, FIG. 56, FIG. 57 e FIG.58 apresentam os gráficos das áreas das bandas normalizadas correspondentes à amida I e água, carbonato, e colágeno, respectivamente, em função da densidade de energia utilizada na irradiação.

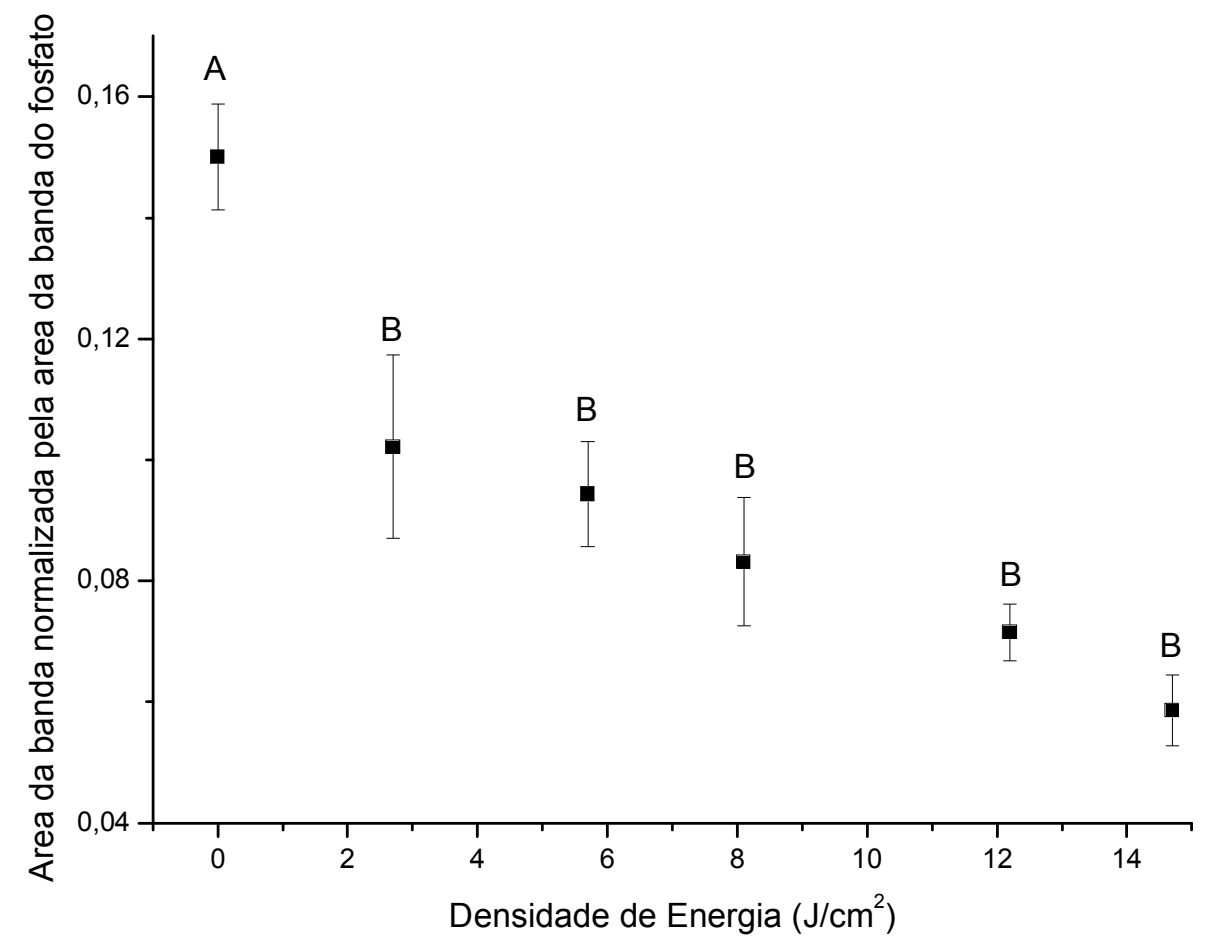

FIGURA 54- Área sob a banda da amida I e água normalizada pela área da banda do fosfato em função da densidade de energia utilizada na irradiação. Letras diferentes representam dados significativamente diferentes; e letras iguais dados que não apresentam diferença estatística. 
Observando-se as razões entre a área sob a banda da amida I e água e da área sob a banda do fosfato (FIG. 54), verifica-se uma tendência de diminuição do conteúdo de amida I e água nas amostras com o aumento da densidade de energia utilizada na irradiação. Entretanto, estatisticamente, está diferença só é significativa nas amostras não irradiadas em relação às irradiadas.

É importante ressaltar que nesta região do espectro ocorre sobreposição da banda da água e da banda da Amida I, portanto é impossível dizer se a diferença encontrada nas amostras irradiadas deve-se à perda de água ou perda de amida I, ou perda de ambos.

Na FIG. 55, são apresentadas as áreas sob a banda referente a amida II e carbonato para os diferentes grupos. A barra de erro para alguns pontos do gráfico é muito pequeno, não sendo visível considerando a escala do gráfico apresentado, estando embutido no tamanho do próprio ponto.

Novamente é observada uma tendência da diminuição do componente com o aumento da densidade de energia. Existe diferença estatisticamente significante entre o grupo das amostras não irradiadas em relação aos grupos irradiados com densidade de energia igual ou maior que $5,7 \mathrm{~J} / \mathrm{cm}^{2}$, não sendo encontradas diferenças estatísticas significantes entre as amostras não irradiadas e irradiadas com 2,7 J/ $\mathrm{cm}^{2}$, indicando que está densidade de energia não é suficientemente grande para causar diminuição no conteúdo de Amida II. 


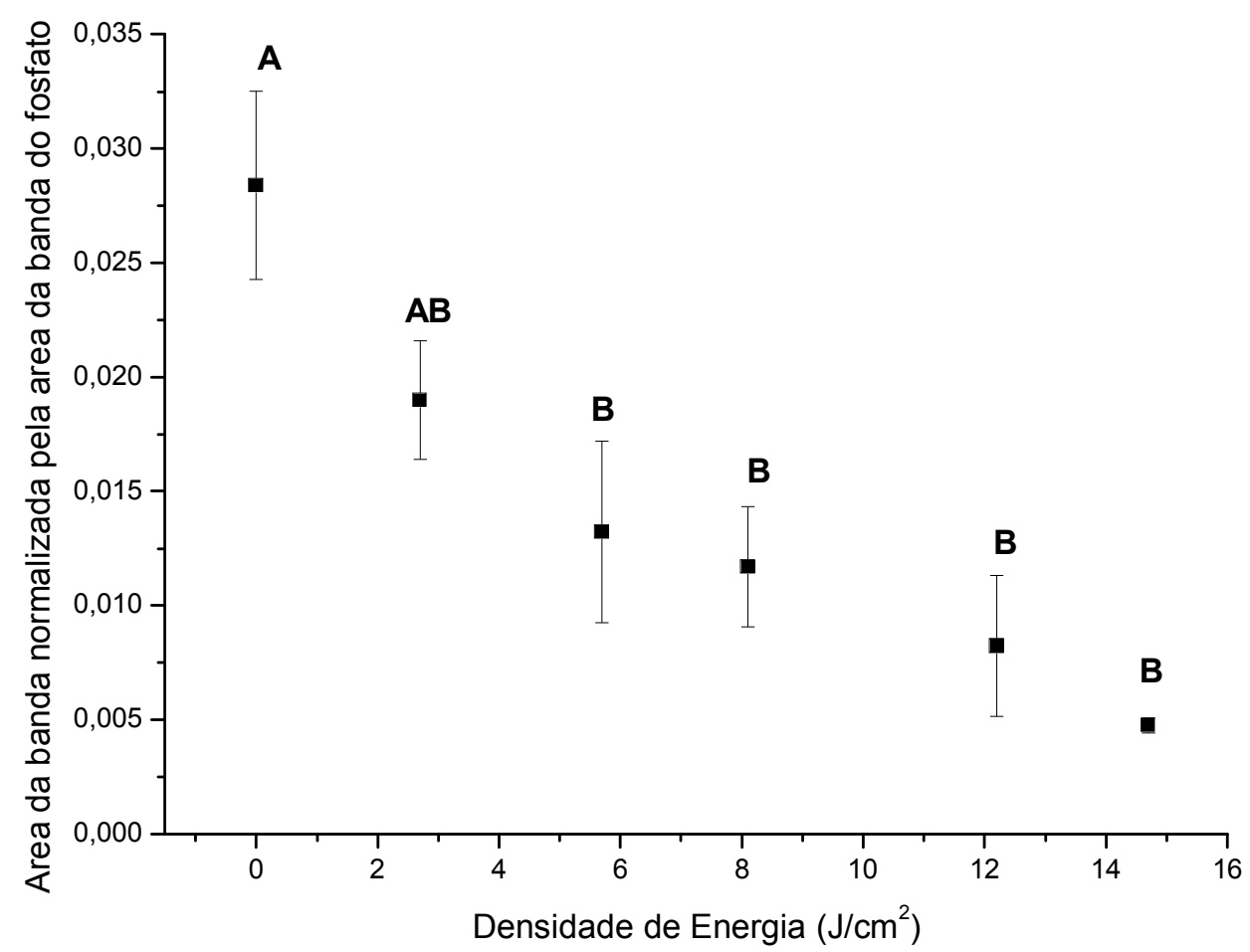

FIGURA 55- Área sob a banda da amida II e carbonato normalizada pela área da banda do fosfato em função da densidade de energia utilizada na irradiação. Letras diferentes representam dados significativamente diferentes; e letras iguais dados que não apresentam diferença estatística.

Apesar de sobrepreposição das bandas de amida II e carbonato, é mais provável que a diminuição da área sob a banda deve-se a perda de amida II, visto que está é termicamente mais instável que o carbonato, como pode ser verificado na FIG. 6, apresentada na seção 3.2.

Na FIG. 56, o gráfico das áreas normalizadas em função da densidade de energia para a banda do carbonato $\left(1445 \mathrm{~cm}^{-1}\right)$ é apresentado. Não é verificada nenhuma alteração. Estatisticamente os grupos não apresentaram nenhuma diferença significante, mostrando que a irradiação não altera esta banda de carbonato. 


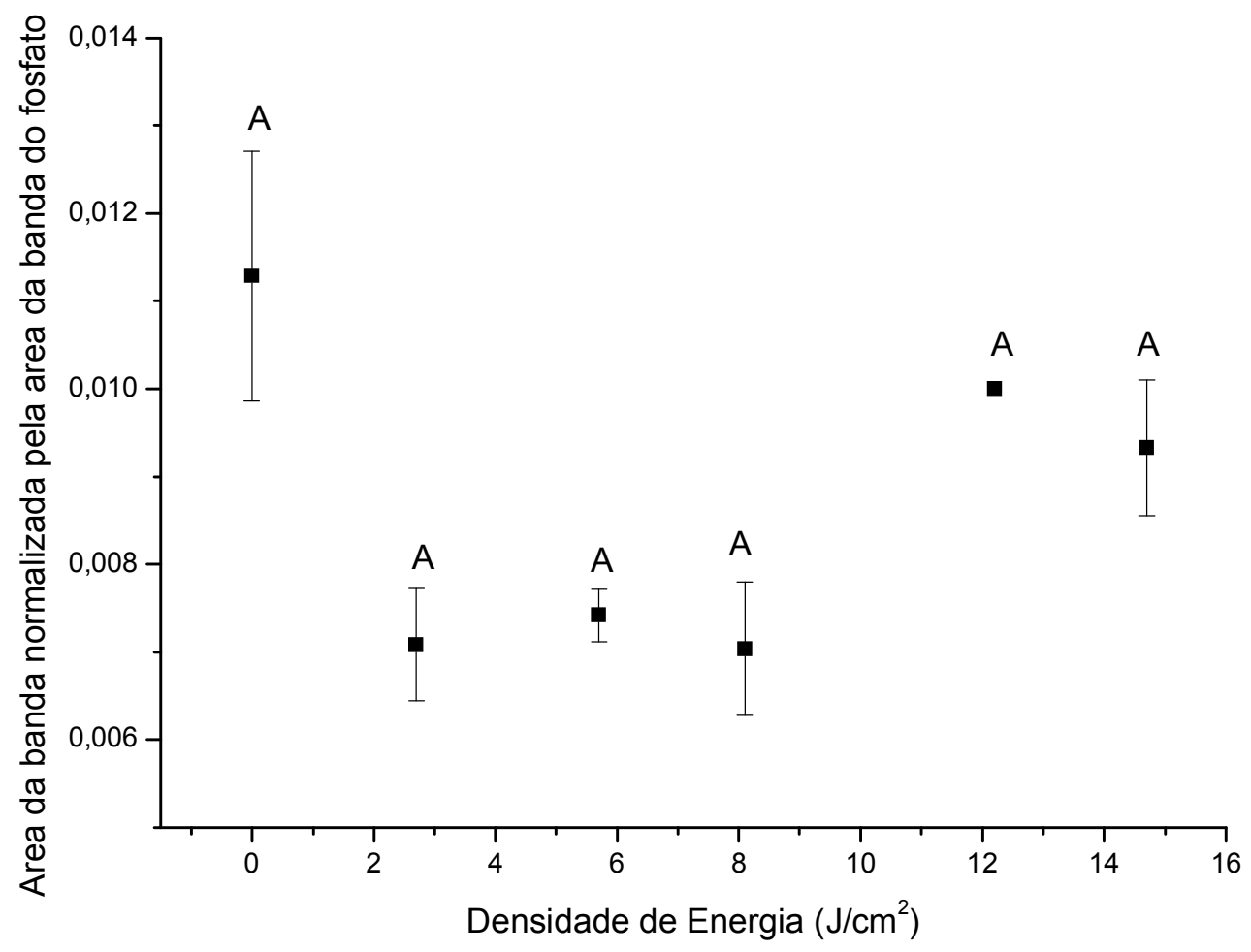

FIGURA 56- Área sob a banda do carbonato normalizada pela área da banda do fosfato em função da densidade de energia utilizada na irradiação. Letras diferentes representam dados significativamente diferentes; e letras iguais dados que não apresentam diferença estatística.

O gráfico da área sob da banda do carbonato $\left(1410 \mathrm{~cm}^{-1}\right)$ normalizada em função da densidade de energia utilizada na irradiação das amostras é apresentado na FIG. 57. É observada uma tendência da diminuição do conteúdo de carbonato com o aumento da densidade de energia. Existe diferença estatisticamente significante entre os grupos irradiados com densidade de energia igual ou maior que $5,7 \mathrm{~J} / \mathrm{cm}^{2}$ em relação as amostras não irradiadas.

A banda do carbonato localizada em $1410 \mathrm{~cm}^{-1}$, aproximadamente, está sobreposta a uma banda de colágeno, portanto a redução de conteúdo observada pode ser devido à diminuição de colágeno na amostra, e não necessariamente à uma alteração na quantidade de carbonato. 


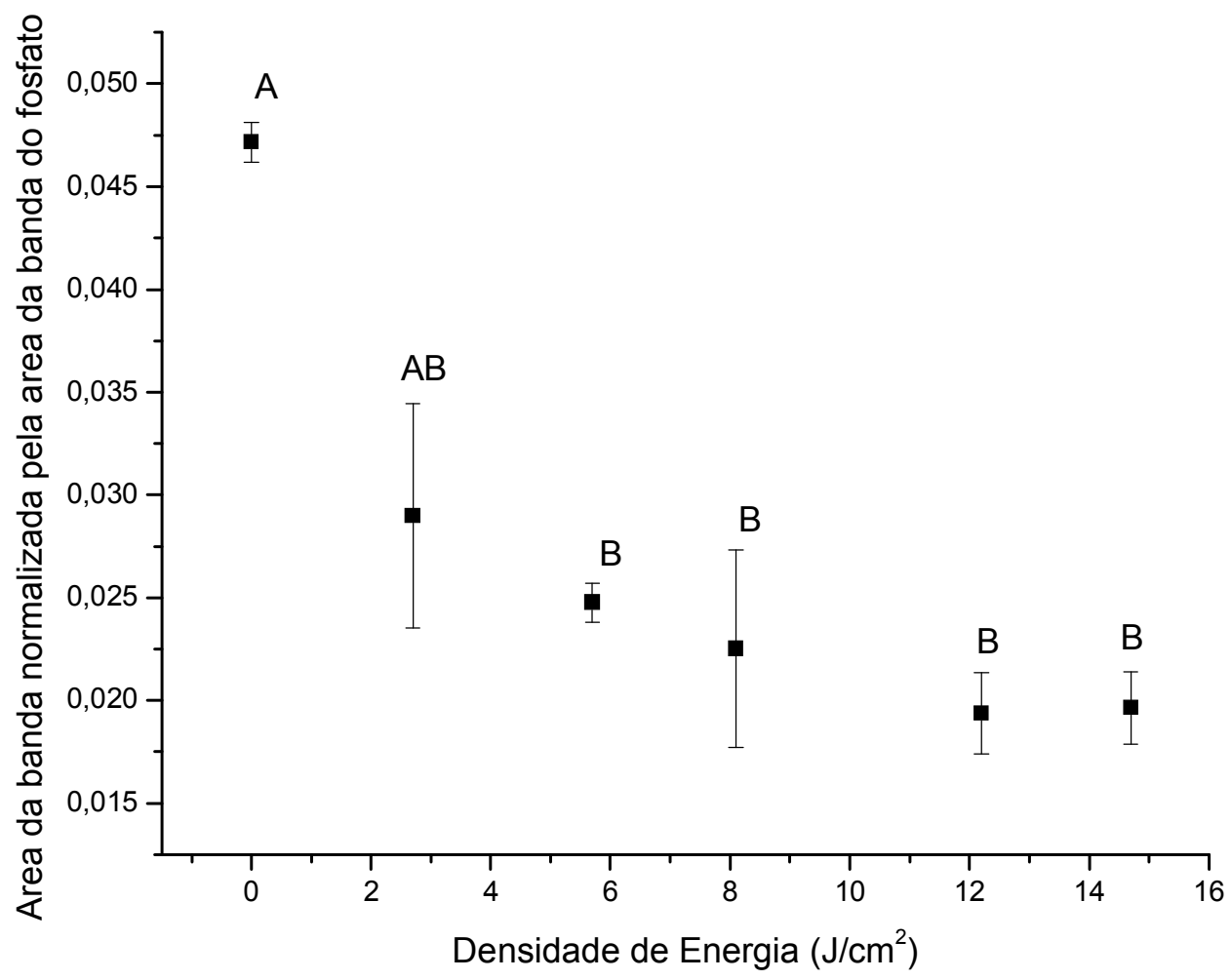

FIGURA 57- Área sob a banda do carbonato normalizada pela área da banda do fosfato em função da densidade de energia utilizada na irradiação. Letras diferentes representam dados significativamente diferentes; e letras iguais dados que não apresentam diferença estatística.

As áreas sob as bandas correspondentes ao colágeno $\left(1335 \mathrm{~cm}^{-1}\right)$ pela densidade de energia são apresentadas na FIG. 59. Não há diferença estatisticamente significante entre os grupos, entretanto é possível perceber uma tendência da diminuição do conteúdo de colágeno com o aumento da densidade de energia utilizada na irradiação. 


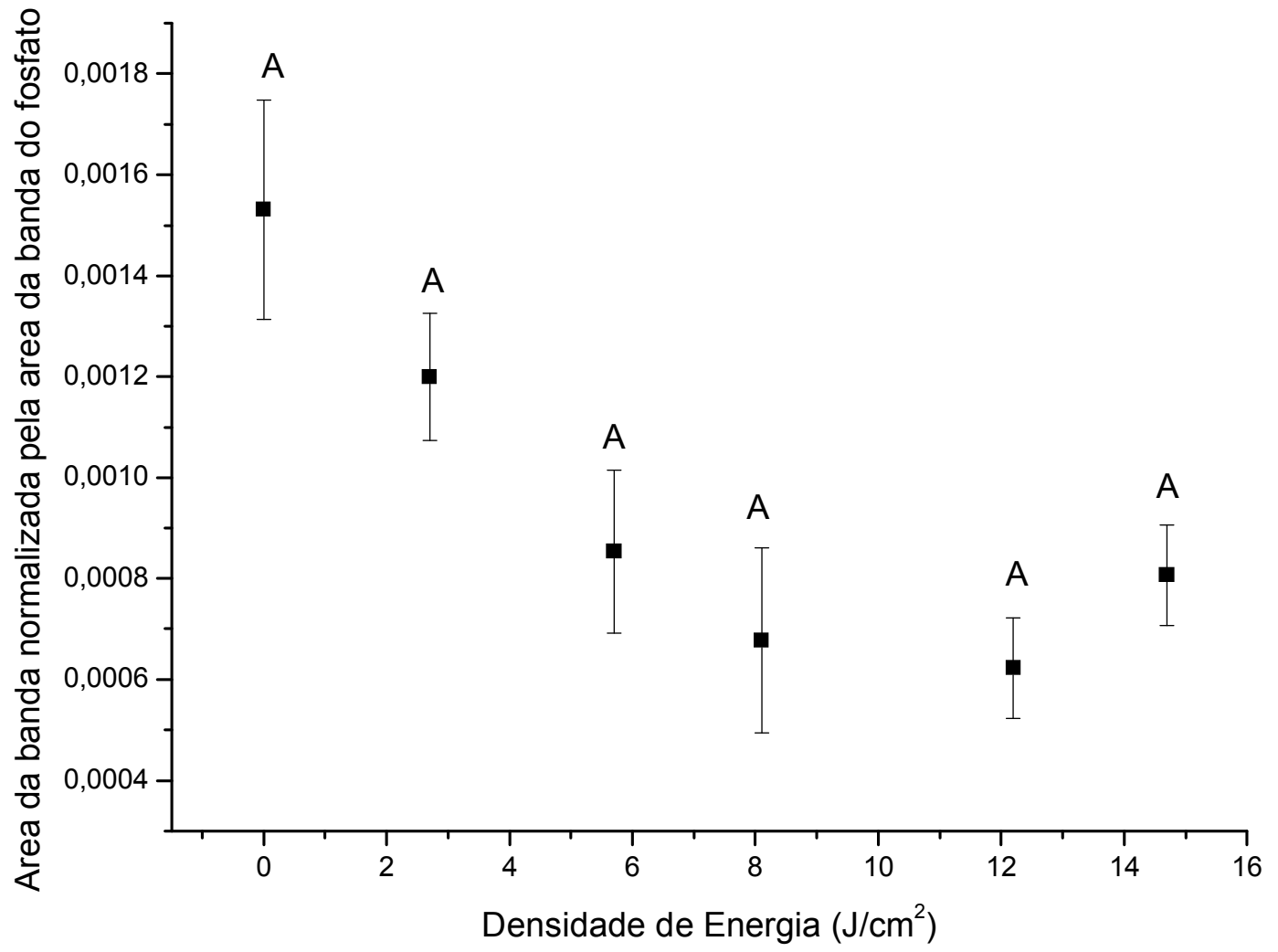

FIGURA 59- Área sob a banda do colágeno $\left(1335 \mathrm{~cm}^{-1}\right)$ normalizada pela área da banda do fosfato em função da densidade de energia utilizada na irradiação. Letras diferentes representam dados significativamente diferentes; e letras iguais dados que não apresentam diferença estatística.

\subsubsection{Região espectral de $1300 \mathrm{~cm}^{-1}$ a $1180 \mathrm{~cm}^{-1}$}

A FIG. 60, referente a região espectral de $1300-1180 \mathrm{~cm}^{-1}$, que evidencia as bandas da amida III e colágeno. É notável o achatamento das três bandas conforme o aumento da densidade de energia, indicando perda gradativa destes componentes. Não foram detectadas mudanças expressivas na posição e largura das bandas. 


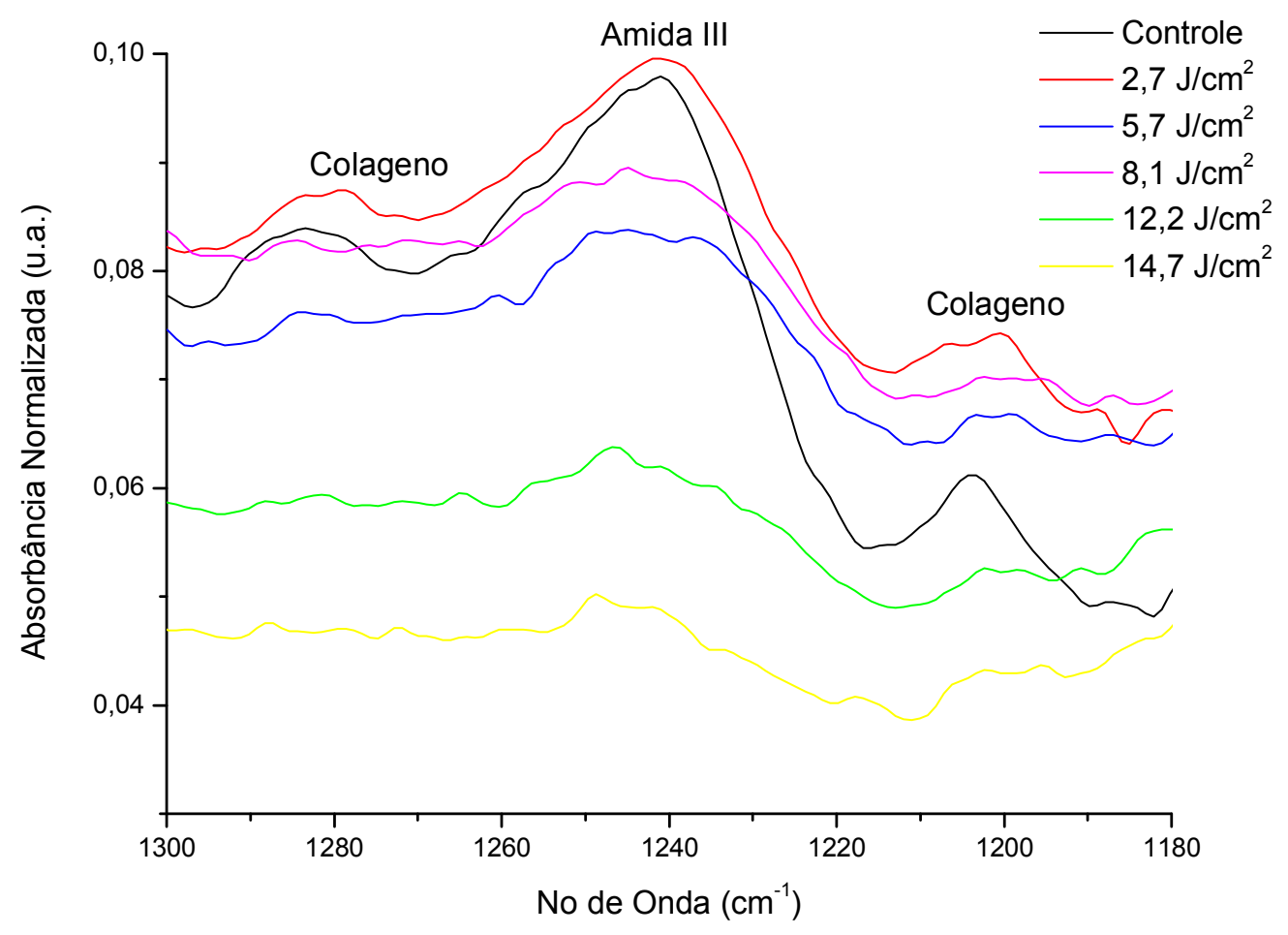

FIGURA 60 - Região espectral de 1300 a $1180 \mathrm{~cm}^{-1}$ de uma amostra de cada um dos grupos analisados.

A FIG. 61 representa o conteúdo das bandas pela densidade de energia para a banda do colágeno com posição central em aproximadamente $1285 \mathrm{~cm}^{-1}$. Não é observada nenhuma diferença estatisticamente significante, entretanto, é observada uma tendência de queda do conteúdo de colágeno com o aumento da densidade de energia. Neste caso, a análise estatística não mostra diferença entre os grupos, devido ao grande erro padrão associados as amostras. 


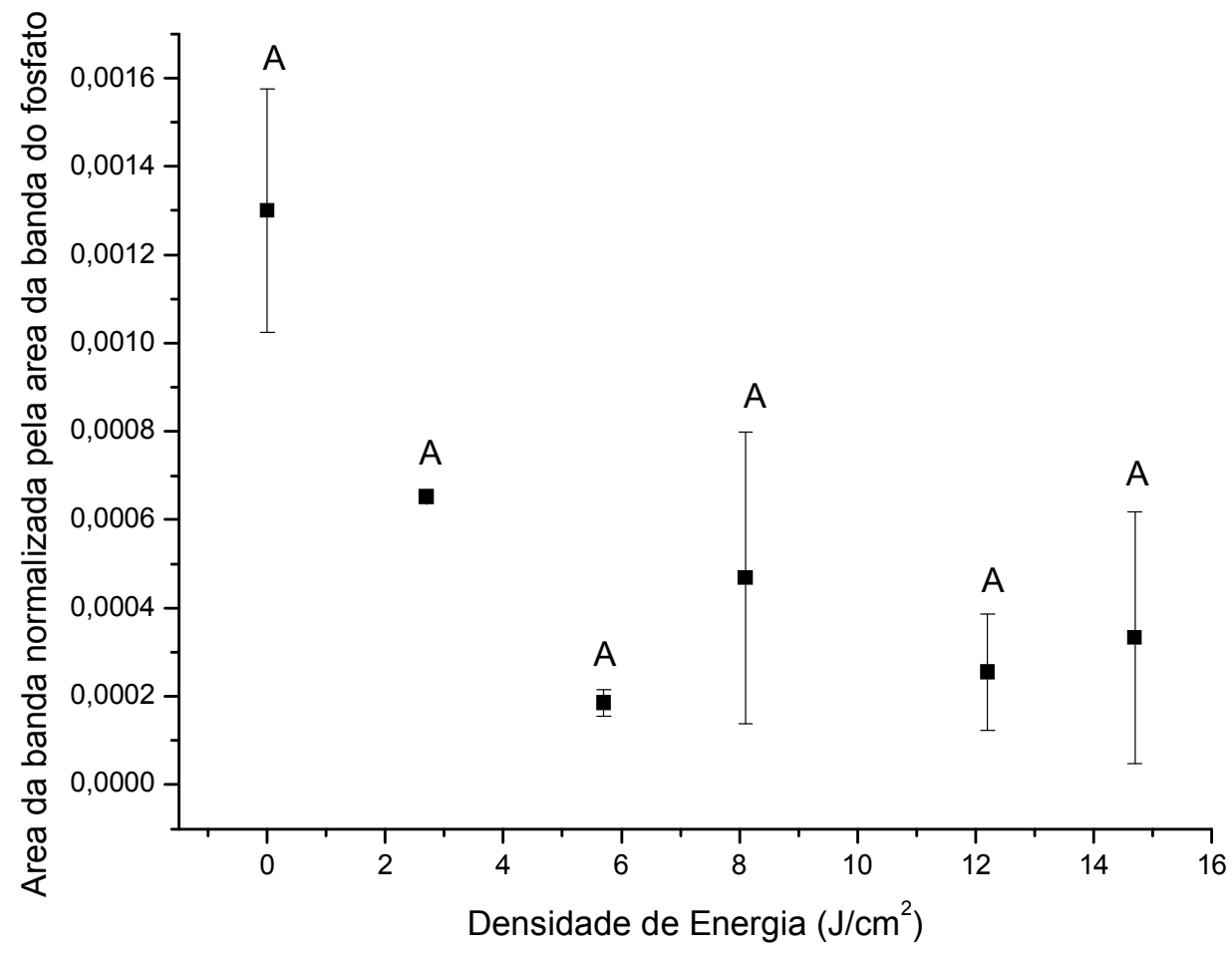

FIGURA 61- Área sob a banda do colágeno normalizada pela área da banda do fosfato em função da densidade de energia utilizada na irradiação. Letras diferentes representam dados significativamente diferentes; e letras iguais dados que não apresentam diferença estatística.

NA FIG. 62, é apresentado o gráfico das áreas sob a banda da Amida II em função da densidade de energia. É observada uma tendência de diminuição no conteúdo de Amida III nas amostras com o aumento da densidade de energia utilizada na irradiação. Há diferenças estatisticamente significantes entre o grupo das amostras não irradiadas em relação aos grupos das amostras irradiadas com densidade de energia igual ou superior a $5,7 \mathrm{~J} / \mathrm{cm}^{2}$, indicando que densidade de energia $2,7 \mathrm{~J} / \mathrm{cm}^{2}$ não causou perda significativa no conteúdo de Amida III das amostras. 


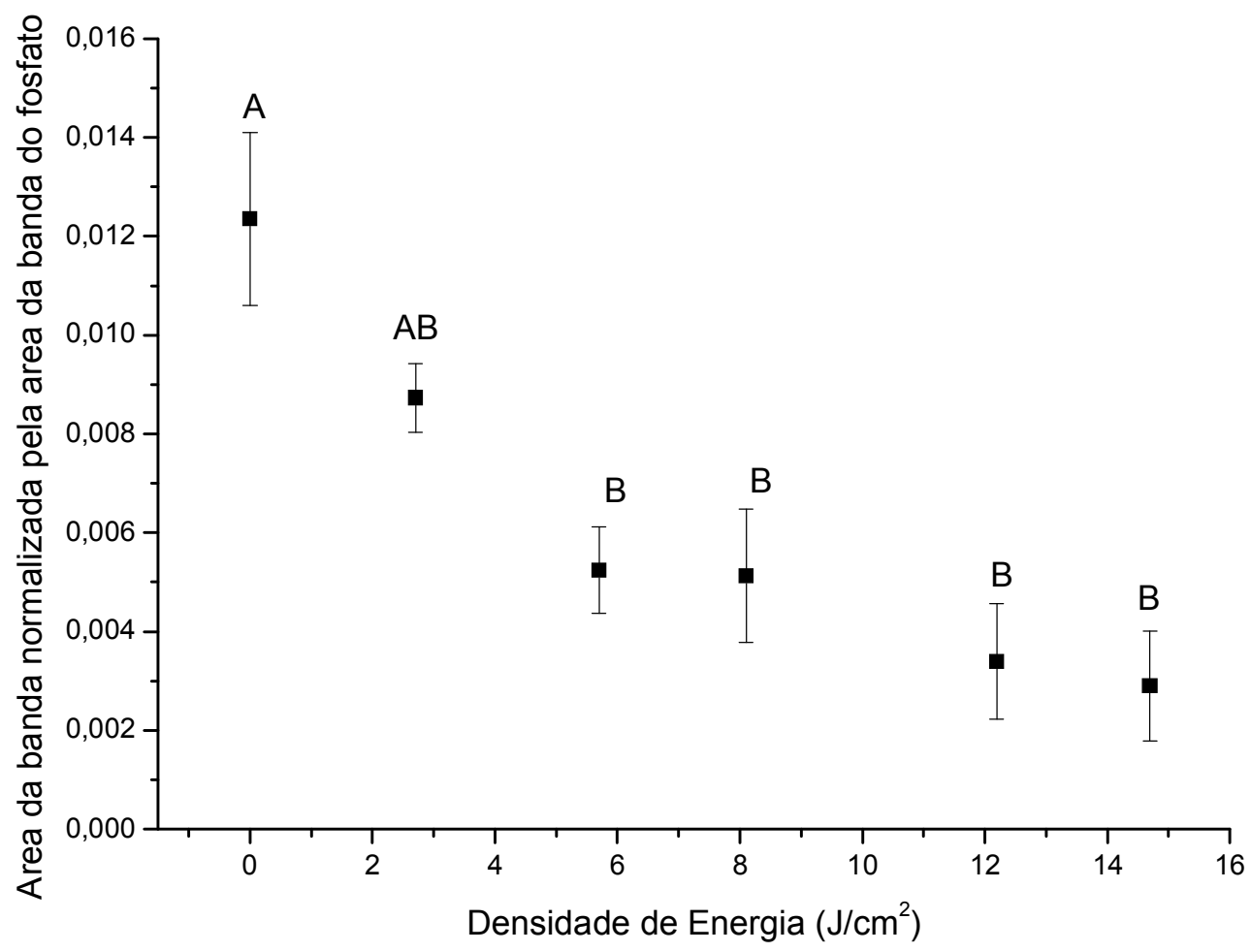

FIGURA 62- Área sob a banda da amida III normalizada pela área da banda do fosfato em função da densidade de energia utilizada na irradiação. Letras diferentes representam dados significativamente diferentes; e letras iguais dados que não apresentam diferença estatística.

Na FIG. 63 é apresentada a áreas normalizadas da banda de absorção do colágeno (1203 $\mathrm{cm}^{-1}$ ) em função da densidade de energia utilizada na irradiação. O erro para alguns pontos do gráfico é muito pequeno, não sendo visível considerando a escala do gráfico apresentado, estando embutido no tamanho do próprio ponto. É observada uma tendência de diminuição do conteúdo de colágeno com o aumento da densidade de energia. Há diferenças estatisticamente significantes entre o grupo das amostras não irradiadas em relação aos grupos irradiados com densidade de energia igual ou superior a $5,7 \mathrm{~J} / \mathrm{cm}^{2}$, exatamente como ocorreu com o conteúdo de amida III. 


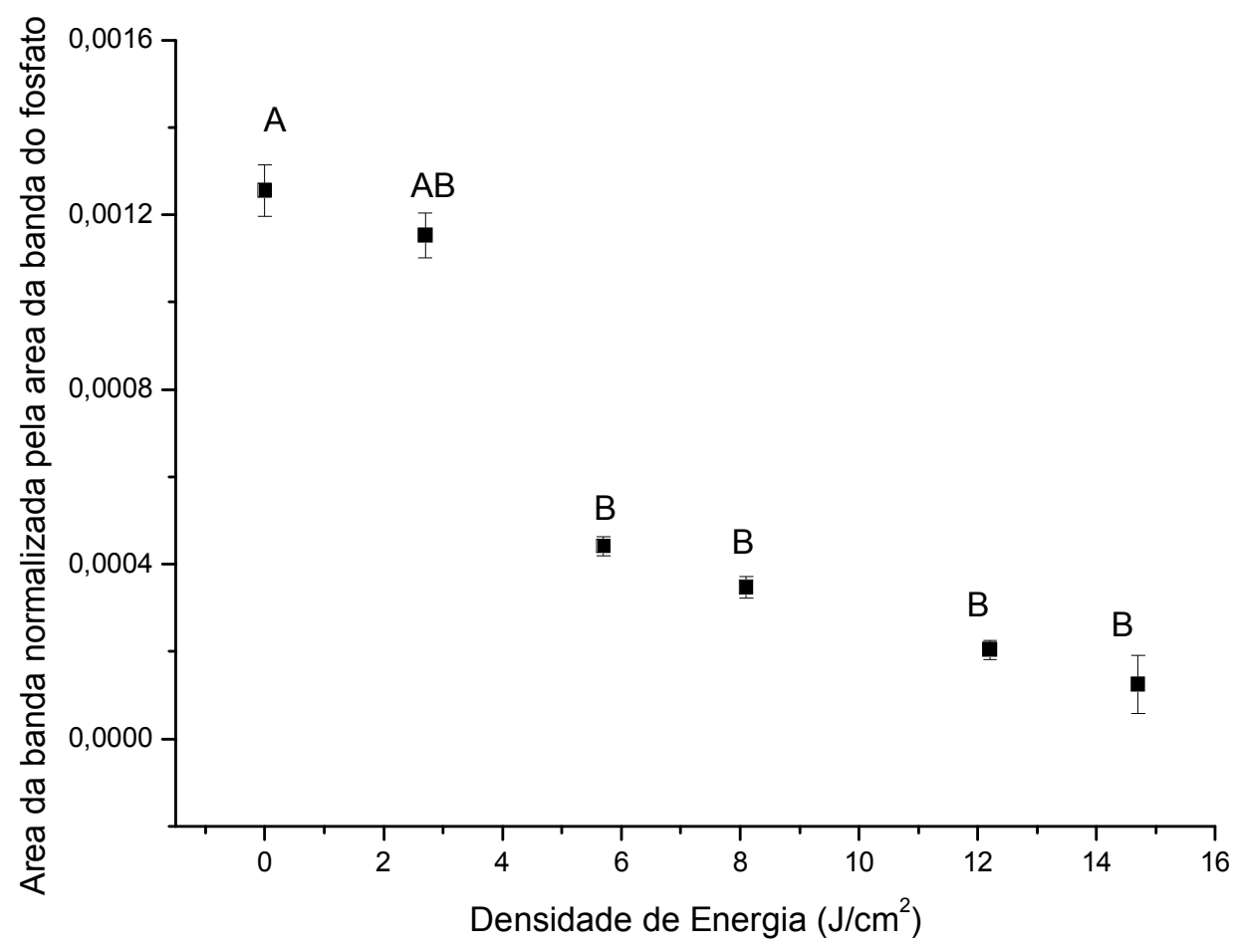

FIGURA 63- Área sob a banda do colágeno $\left(1203 \mathrm{~cm}^{-1}\right)$ normalizada pela área da banda do fosfato em função da densidade de energia utilizada na irradiação. Letras diferentes representam dados significativamente diferentes; e letras iguais dados que não apresentam diferença estatística.

\subsubsection{Região espectral de $1180 \mathrm{~cm}^{-1}$ a $800 \mathrm{~cm}^{-1}$}

A FIG. 64 apresenta os espectros de diferentes grupos na região espectral de $1180-800 \mathrm{~cm}^{-1}$, onde são encontradas bandas de absorção do fosfato (1003 $\left.\mathrm{cm}^{-1}\right)$ e do carbonato $\left(870 \mathrm{~cm}^{-1}\right)$. Não é verificada nenhuma alteração nas bandas quanto à sua posição, forma ou largura. 


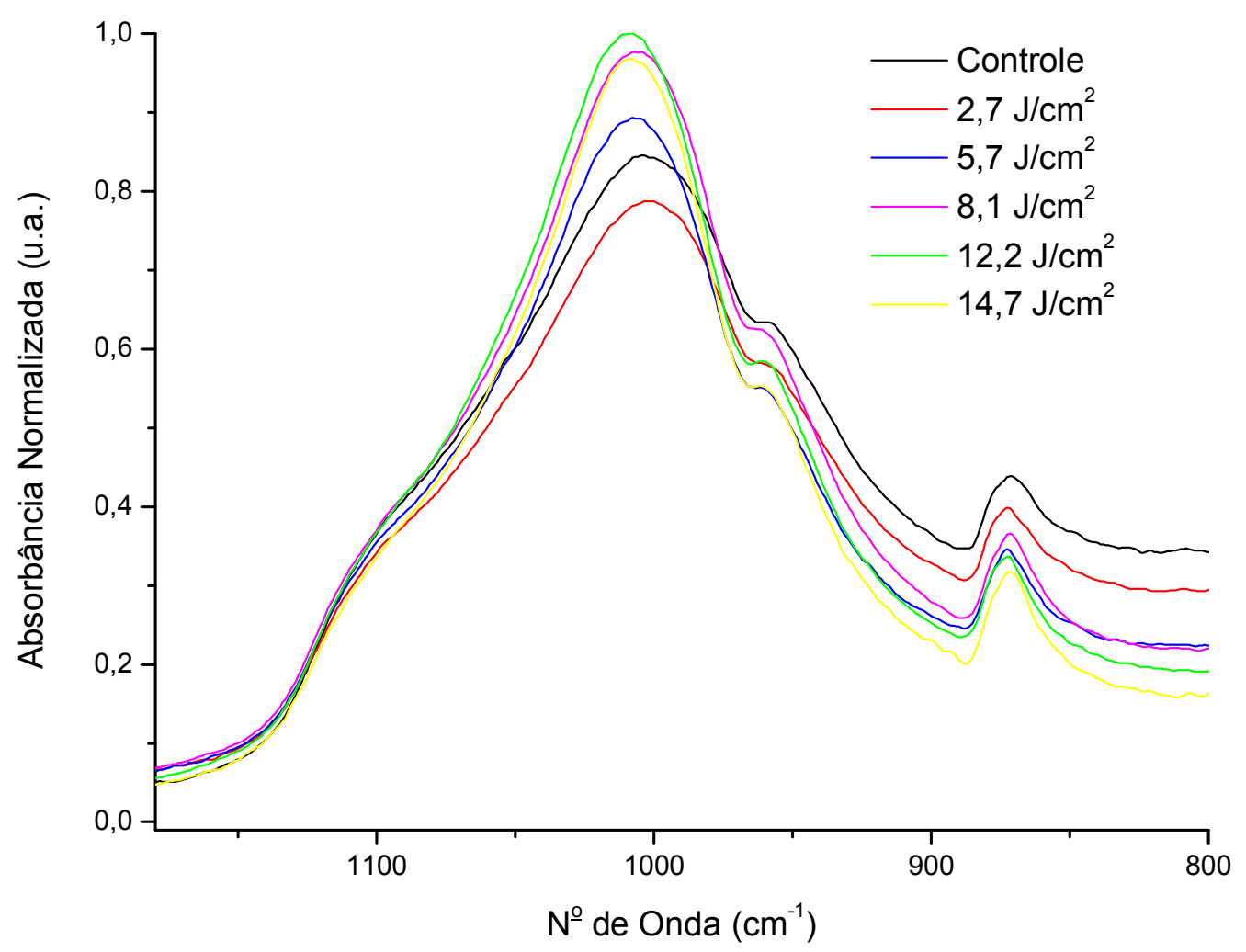

FIGURA 64- Região espectral de $1300 \mathrm{a} 1180 \mathrm{~cm}^{-1}$ de uma amostra de cada um dos grupos analisados.

Como a área sob a banda do fosfato $\left(1003 \mathrm{~cm}^{-1}\right)$ é utilizada na normalização das demais bandas, não é possível analisar a variação do seu conteúdo com a densidade de energia utilizada na irradiação.

A FIG. 65 mostra o gráfico da área sob a banda do carbonato $\left(870 \mathrm{~cm}^{-1}\right)$ normalizada em função da densidade de energia utilizada na irradiação. Não há diferença estatisticamente significante entre os grupos, e também nenhuma tendência foi observada. 


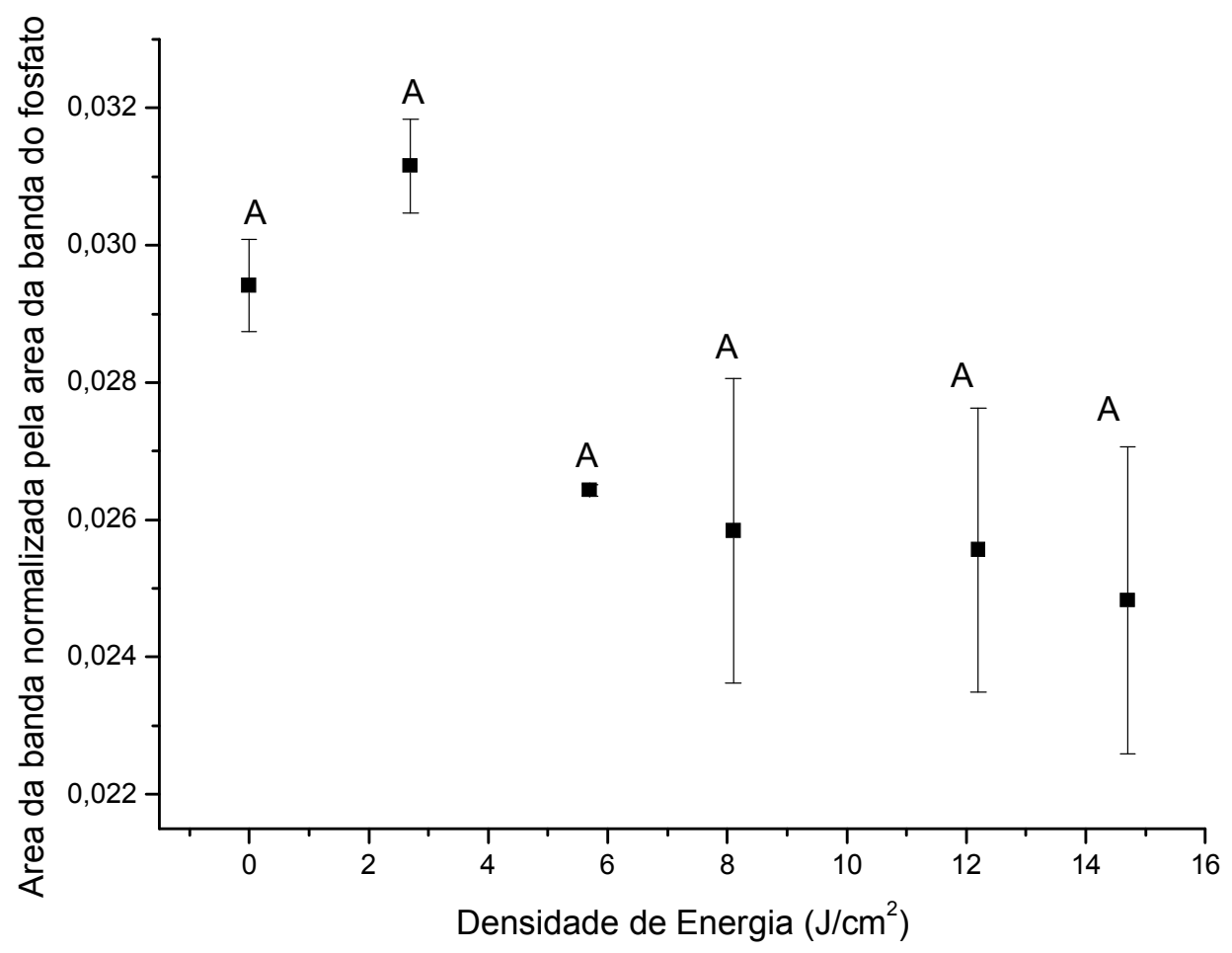

FIGURA 65- Área sob a banda do carbonato $\left(870 \mathrm{~cm}^{-1}\right)$ normalizada pela área da banda do fosfato em função da densidade de energia utilizada na irradiação. Letras diferentes representam dados significativamente diferentes; e letras iguais dados que não apresentam diferença estatística.

\subsubsection{Região espectral de $850 \mathrm{~cm}^{-1}$ a $550 \mathrm{~cm}^{-1}$}

A região espectral de $850-550 \mathrm{~cm}^{-1}$, onde estão as bandas de absorção do libração $\mathrm{OH}^{-}$(em aproximadamente $680 \mathrm{~cm}^{-1}$ ) e fosfato $\left(595 \mathrm{~cm}^{-1}\right)$, são apresentadas na FIG 66. A banda do fosfato não sofreu deformação, alargamento ou mudança de posição, mas é observado um achatamento da banda correspondente ao $\mathrm{OH}^{-}$, indicando perda deste componente com a irradiação, sendo esta perda mais acentuada quanto maior a densidade de energia utilizada. 


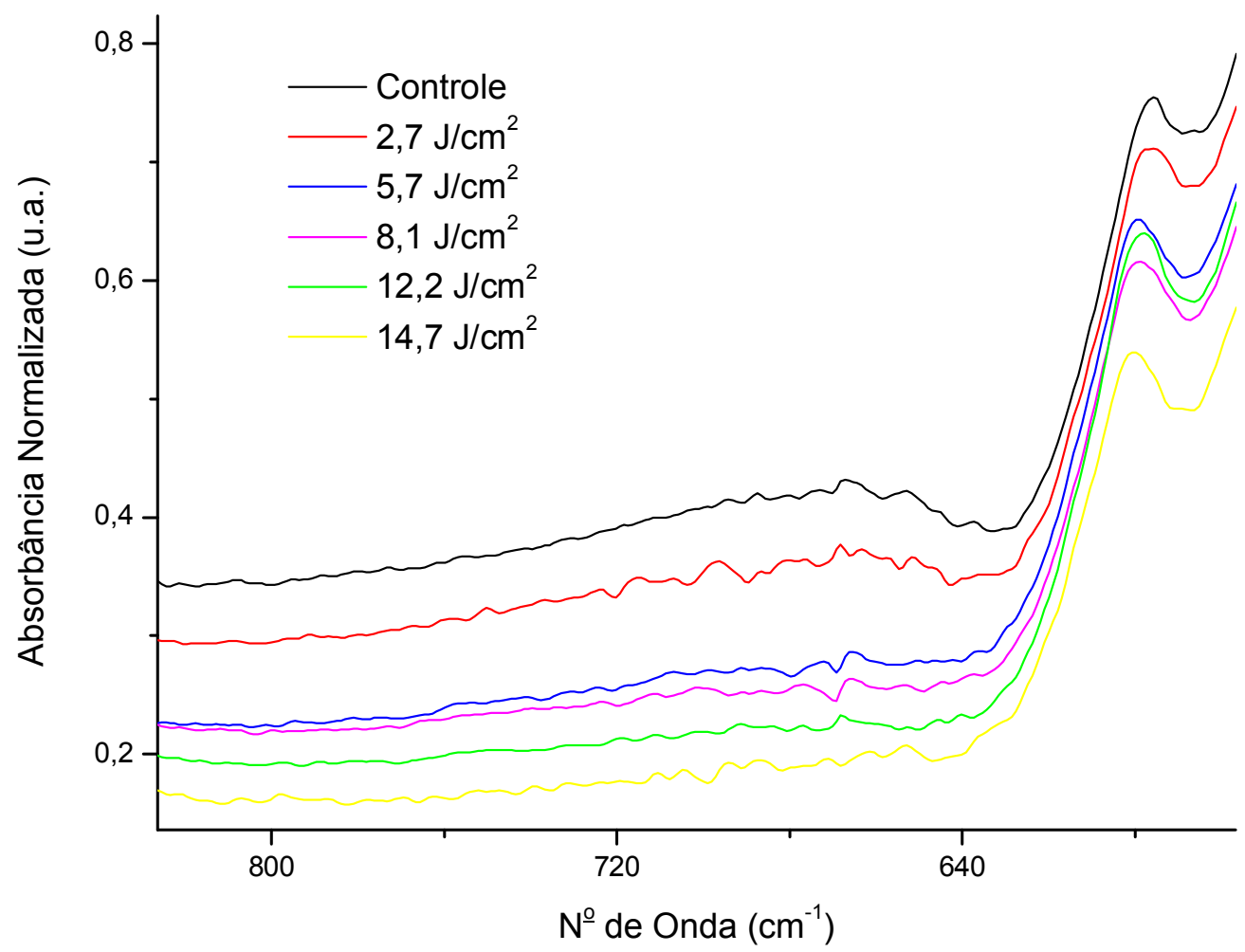

FIGURA 66 - Região espectral de 850 a $550 \mathrm{~cm}^{-1}$ de uma amostra de cada um dos grupos analisados. Letras diferentes representam dados significativamente diferentes; e letras iguais dados que não apresentam diferença estatística.

$\mathrm{Na}$ FIG 67, onde é apresentado o gráfico da área normalizada pela densidade de energia da banda correspondente a vibração $\mathrm{OH}^{-}$, é observada uma perda significativa de conteúdo quando as amostras foram irradiadas com energias iguais ou maiores que $5,7 \mathrm{~J} / \mathrm{cm}^{2}$. A energia de $2,7 \mathrm{~J} / \mathrm{cm}^{2}$ não causou perda significativa no conteúdo de $\mathrm{OH}^{-}$. 


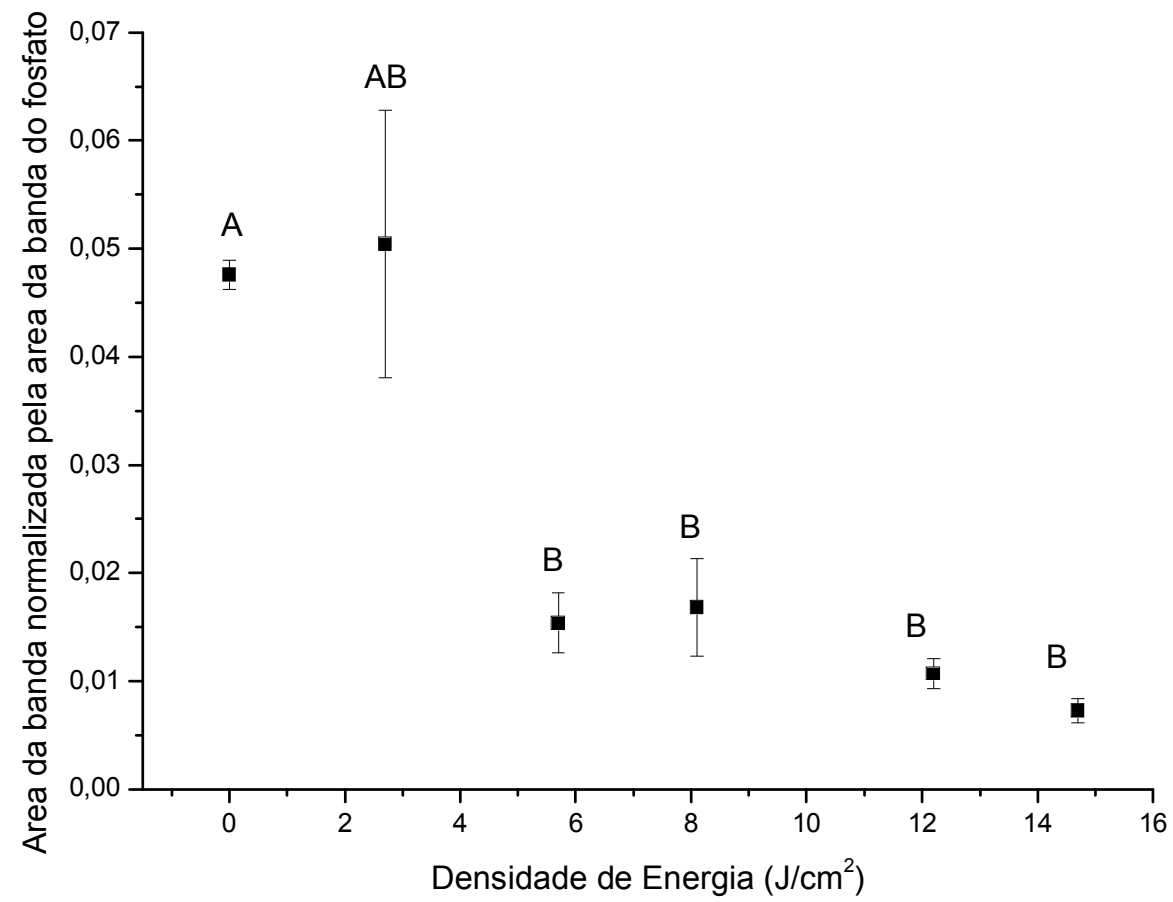

FIGURA 67- Área sob a banda do $\mathrm{OH}^{-}$normalizada pela área da banda do fosfato em função da densidade de energia utilizada na irradiação. Letras diferentes representam dados significativamente diferentes; e letras iguais dados que não apresentam diferença estatística.

Na FIG. 68, são apresentadas as áreas normalizadas sob a banda de absorção do fosfato $\left(595 \mathrm{~cm}^{-1}\right)$ em função da densidade de energia utilizada na irradiação. Não são observadas diferenças estatisticamente significantes entre os grupos, indicando que a irradiação não altera o conteúdo de fosfato nas amostras. Este fato é reforçado por não ter sido observada nenhuma tendência de alteração. 


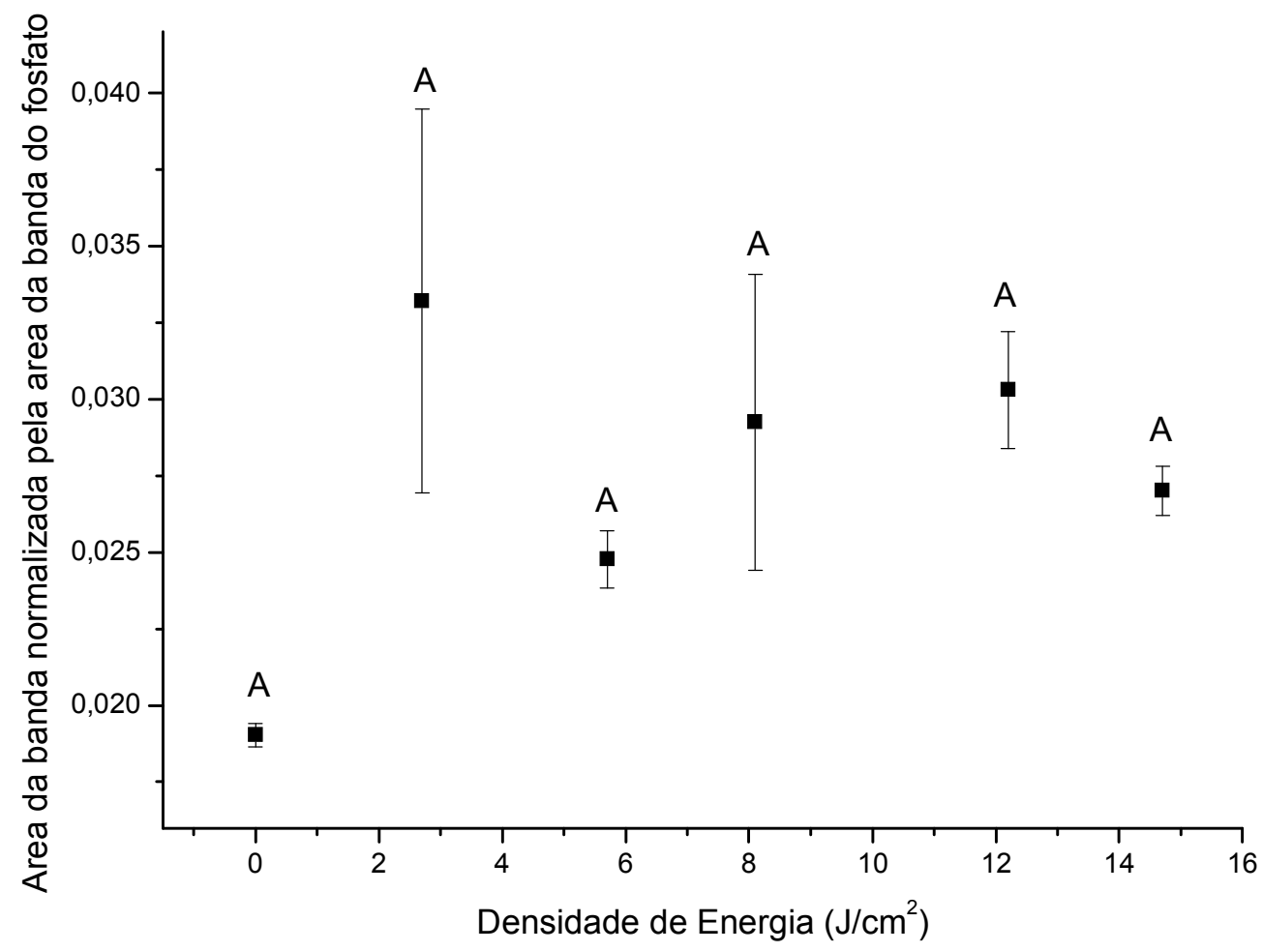

FIGURA 68- Área sob a banda do fosfato normalizada pela área da banda do fosfato em função da densidade de energia utilizada na irradiação. Letras diferentes representam dados significativamente diferentes; e letras iguais dados que não apresentam diferença estatística. 


\section{DISCUSSÂO}

Desde a primeira aplicação bem sucedida de lasers em tecidos duros ${ }^{5}$, a irradiação laser vem sido extensivamente utilizada em cirurgias de cartilagem, ossos e dentes, oferecendo benefícios para o cirurgião, tornando possível a realização de procedimentos com melhor visualização, de forma minimamente invasiva e com pequeno dano térmico ou mecânico ${ }^{1}$. Também oferece vantagens ao paciente, garantindo um período pós-operatório mais rápido e confortável na maior parte dos casos. Considerando o amplo uso da irradiação do laser na cirurgia de tecidos duros, é importante conhecer as alterações químicas que ocorrem no tecido irradiado, com o objetivo de avaliar se os parâmetros laser utilizados podem afetar o processo de cicatrização.

\subsection{Considerações Gerais}

A técnica espectroscópica ATR-FTIR mostrou-se adequada para caracterizar amostras de osso irradiadas e não irradiadas, uma vez que foi possível estimar as mudanças composicionais ocorridas devido à irradiação. A maioria das bandas reportadas na literatura ${ }^{13,53,55,57}$ para este tipo de tecido foi localizada com facilidade, por apresentarem boa intensidade em relação ao ruído dos espectros. Este fato mostra a importância do estudo das melhores condições de ajuste instrumental para a aquisição dos espectros.

Quanto às posições das bandas, as pequenas diferenças entre os valores reportados na literatura, apresentados na TAB. 2, TAB. 3, TAB 4, e TAB. 5 e os valores encontrados TAB. 15 deve-se ao fato de que, normalmente, os valores da literatura referem-se ao intervalo onde a banda é encontrada e não à sua posição central. Entretanto, também podem ocorrer variações entre espectros adquiridos por diferentes equipamentos, sendo natural encontrar diferenças de até $10 \mathrm{~cm}^{-1}$ entre as posições e os intervalos das bandas entre os estudos ${ }^{53,55,57}$. Logo, é importante que a comparação entre amostras irradiadas e não irradiadas sejam realizadas com espectros obtidos de um mesmo equipamento. 
Na seção 5.3, onde são apresentados os resultados do estudo das formas de analise dos espectros, fica clara a impossibilidade de comparação direta entre os espectros para uma analise semiquantitativa, visto que mesmo os espectros obtidos de uma mesma amostra apresentam diferenças quanto às intensidades das bandas. Essa diferença pode ser originada por diversas razões, como irregularidades na superfície das amostras, principalmente as provenientes das amostras irradiadas, o que poderia influenciar na reflexão do sinal, ou o fato do equipamento ATR-FTIR utilizado não possibilitar o controle da pressão aplicada sobre a amostra, quando esta é pressionada contra o cristal de diamante. Ambos os casos dificultam a padronização do contato entre a amostra e o cristal e, consequentemente, a absorção do feixe pela amostra, o que está diretamente relacionado com a intensidade das bandas.

O procedimento experimental utilizado na preparação das amostras não irradiadas descrito na seção 4.1, torna a superfície destas bastante regulares e portanto, é improvável que alguma irregularidade das amostras seja o principal motivo das diferenças de intensidade observadas. Deste modo, acredita-se que a falta de controle da pressão exercida sobre as amostra seja a principal responsável pelas diferenças de intensidade em espectros obtidos de uma mesma amostra. Entretanto também é necessário considerar as diferenças naturais do tecido osso, que como qualquer material biológico não é totalmente homogêneo, e portanto a absorção e reflexão podem ocorrer em intensidades diferentes para distintas regiões das amostras.

Independente da causa, as diferenças de intensidade entre os espectros revelam que é essencial a sua normalização para realizar análises semiquantitativas, sendo que apenas a comparação ente a largura, posição central e forma das bandas podem ser realizadas sem a normalização dos espectros.

Neste estudo foram testadas três normalizações: pela intensidade da banda do fosfato correspondente a vários estados de vibração (1300-900 cm${ }^{-1}$ ), pela área da banda do fosfato $\left(1300-900 \mathrm{~cm}^{-1}\right)$ e pela área total do espectro. Entretanto nenhum método se mostrou adequado para a correção, visto que as 
intensidades dos espectros não ficaram sobrepostas em toda região espectral (FIG. 40, FIG. 42 e FIG. 44). Esse fato não impede uma análise semiquantitativa, mas impossibilita uma análise semiquantitativa direta, isto é, não é possível, mesmo com a normalização, simplesmente comparar os espectros graficamente para verificar alguma alteração de conteúdo. Portanto cada banda teve que ser estudada individualmente.

A área sob uma banda corresponde à quantidade de seus componentes na amostra. Portanto, para uma comparação semiquantitativa dos componentes do tecido ósseo, basta normalizar as áreas sob cada uma das bandas pela área de um componente específico que não sofra alteração com o tratamento feito nas amostras $^{42,13}$. Neste estudo, onde as amostras foram irradiadas por um laser de alta intensidade de comprimento de onda altamente absorvido pelo tecido ósseo e, consequentemente, sofreram aumento de temperatura ${ }^{57,59}$, a normalização foi feita utilizando-se a área da banda do fosfato $\left(1300-900 \mathrm{~cm}^{-1}\right)$, referente aos modos de vibração $v_{1}$ e $v_{3}$, uma vez que é o componente mais estável do osso quando ocorre apenas aumento térmico deste tecido ${ }^{59,60}$, como pode ser observado na TAB. 4. Portanto, baseamos as análises no fato que a área sob a banda do fosfato $\left(1300-900 \mathrm{~cm}^{-1}\right)$ não sofra alteração ou seja minimamente alterada com a irradiação e, portanto, ela poderia ser utilizada como paramento de comparação para os outros componentes, tal como é realizado em estudos da literatura que comparam amostras de tecido duro dental não irradiados e irradiados $^{13,14,17}$. Optou-se por utilizar a área sob esta banda $\left(1300-900 \mathrm{~cm}^{-1}\right) \mathrm{e}$ não a área sob a banda da vibração $v_{4}$ do fosfato $\left(595 \mathrm{~cm}^{-1}\right)$ pois,embora ambas correspondam ao mesmo componente químico, a primeira é bem mais intensa e melhor definida, como pode ser verificado na FIG. 17.

O método utilizado no cálculo das áreas sob as bandas considera apenas a porção que se sobressai na sobreposição com as outras bandas, não sendo calculada a área total da banda. O método de ajuste de gaussianas, que em teoria calcula toda a área na banda, não foi utilizado devido à dificuldade de localizar algumas das bandas que se apresentam sobrepostas. Uma vez que o método de ajuste de gaussianas propõe determinar a área total das bandas 
considerando a sobreposição, é essencial localizar todas as bandas que se sobrepõem, e não somente as que se destacam na sobreposição. Para isso, em geral é utilizada a segunda derivada para encontrar bandas de difícil visualização, seja por sua pouca intensidade, ou seja devido à sua sobreposição com outras bandas $^{47}$. Entretanto, neste trabalho não foi possível localizar as posições as bandas pela segunda derivada devido ao ruído dos espectros.

A segunda derivada do espectro revela qualquer pequena curvatura ou irregularidade presente no espectro original como sendo uma banda e, portanto, para o seu uso é necessário um espectro livre de ruído. Apesar de, visualmente, os espectros obtidos apresentarem boa qualidade de sinal, para a utilização da segunda derivada eles são excessivamente ruidosos, e não possuem a qualidade necessária. O ruído dos espectros advém em grande parte do vapor d'água do ambiente e da água presente na amostra. A água possui uma grande região de absorção no infravermelho (região de absorção da água), e bandas pouco intensas acabam por tornar o espectro irregular, atrapalhando na identificação de outros componentes por encobrir as bandas menos intensas e por tornar menos definidas as bandas de absorção mais intensas.

Existem diversas formas de tentar diminuir o ruído do espectro. Considerando o estudo inicial de determinação das melhores condições para a aquisição dos espectros, diminuir a resolução do espectrômetro é uma das alternativas, entretanto, isso também diminuiria a precisão nas posições e nas áreas das bandas, o que acabaria por prejudicar outras análises. Outra hipótese seria aumentar o número de varreduras, mas observamos neste trabalho que os espectros obtidos com 120 varreduras não possuem qualidade de sinal expressivamente maior que aqueles obtidos com 40 varreduras, indicando que aumentar o número de varreduras além deste valor não irá melhorar a qualidade de sinal (TAB. 12 e TAB. 13). Normalmente, para tornar os espectros visualmente menos ruidosos, pode ser usada uma ferramenta matemática de suavização para diminuir o ruído dos espectros, como smoothing por Savitzky-Gollay ou a média entre pontos adjacentes. Entretanto, isso pode afetar a resolução dos espectros e alterar a curvatura, tamanho e posição das bandas. Portanto, o uso dessas técnicas não é adequado ao nosso objetivo. 
Como não foi possível melhorar a qualidade de sinal dos espectros além do limite obtido neste trabalho, não foi utilizada a segunda derivada para determinar a posição dos picos, e sim um método direto para o cálculo das áreas. Este método, apesar de não calcular a área integral da banda, é bastante prático e pode ser utilizado em análises semiquantitativas normalizadas sem prejuízo de informações, tendo sido batente utilizado ${ }^{42,54}$.

Empregando-se este método, observou-se que a irradiação do osso com o laser de Er,Cr:YSGG promoveu mudanças químicas significativas. Isso era esperado, visto que o comprimento de onda do laser utilizado $(2,78 \mu \mathrm{m})$ é fortemente absorvido pelos principais constituintes do tecido ósseo: a água e hidroxiapatita $^{8,26,61}$, como pode ser verificado na FIG. 4, na qual apresenta o espectro de absorção deste componentes. Desta foram, a energia do laser de Er,Cr:YSGG é fortemente absorvida por este tecido, sendo eficientemente transformada em calor e, desta maneira, promovendo um aumento significativo da temperatura na superfície, que varia conforme a densidade de energia. Em estudos realizados com esmalte e dentina foram demonstrados que as alterações químicas observadas em amostras irradiadas com laser de alta potenciam emissores no infravermelho são equivalente as modificações caudadas pelo aquecimento em forno das mostras ${ }^{42,54}$.

A mudança na temperatura da superfície durante a irradiação do laser é relatada como a principal responsável pela modificação química de tecidos duros $^{14}$, como descrito anteriormente em dentina e esmalte ${ }^{13,17,53}$. Considerando que o osso tem componentes similares do esmalte e dentina, são esperadas alterações semelhantes, como diminuição dos componentes orgânicos e alteração da cristalinidade ${ }^{42}$.

A irradiação por laser emissor no infravermelho realizado com densidade de energia superior ao limiar de ablação promove o processo de ablação térmica $^{62}$, que é responsável pelo corte de tecidos duros. Isso significa que a energia absorvida pela água é suficiente para fazer com que essa entre em ebulição, o que causa um aumento da pressão dentro do tecido e cria uma 
pequena explosão, que propicia a remoção do material subjacente e a liberação de energia ${ }^{63} 64$. Em tecidos duros mineralizados, onde ocorre ablação térmica, a superfície do tecido pode chegar a $800{ }^{\circ} \mathrm{C}$ quando atingido o limiar de ablação para o laser de Er,Cr:YSGG ${ }^{65}$, sendo que esta temperatura diminui significativamente com o aumento da profundidade. O material que sofre o maior aumento de temperatura é removido com a explosão. O material remanescente não atinge a temperatura necessária para a ablação, mas ainda assim sofre um aumento da temperatura, que pode ser suficiente ou não para induzir mudanças químicas $^{24,42}$. Assim, analisando a superfície do tecido retirado, estamos analisando o material que sofreu um aumento de temperatura inferior a $800^{\circ} \mathrm{C}$.

É importante perceber que, durante a irradiação, a temperatura em que uma determinada região é submetida pode ser diferente da temperatura região circunvizinha. Portanto as alterações causadas pelo aumento de temperatura não são homogêneas no tecido ${ }^{42}$. Desta forma, ao caracterizar o tecido pela técnica de ATR-FTIR, consideramos uma caracterização da variação média da região analisada, já que não é possível diferenciar as regiões que sofreram diferentes aumentos de temperatura.

\subsection{Comparação visual das bandas}

Tanto nas amostras de osso não irradiado quanto nas amostras irradiadas foi possível verificar a presença de todos os elementos considerados para este estudo (água, amidas, colágeno, carbonato e fosfato).

$\mathrm{Na}$ comparação visual entre as amostras naturais e irradiadas com diferentes densidades de energia, não foi verificado o surgimento de uma nova banda, ou mudança expressiva na posição das bandas, o que já foi reportado em estudos anteriores realizados com esmalte e dentina irradiados sob diferentes condições $^{42}$. Na região espectral de $1750 \mathrm{~cm}^{-1}$ a $1250 \mathrm{~cm}^{-1}$, correspondente às bandas de absorção das amidas, foi possível identificar um alargamento gradativo da banda de amida II e carbonato em amostras irradiadas com densidade de energia a partir de $5,7 \mathrm{~J} / \mathrm{cm}^{2}$ (FIG. 53). A largura de banda está relacionada com a cristalinidade do material ${ }^{14}$. Logo, o aumento da largura da banda sugere uma 
modificação da cristalinidade do osso em consequência da irradiação, o que é esperado visto que foi constatada a diminuição do material orgânico, que consequentemente torna o tecido mais cristalino ${ }^{42}$. Entretanto, como esta banda está sobreposta a outras bandas, este alargamento pode ser resultado da diminuição da área da banda que, com isso, evidencia outras bandas às quais está sobreposta.

\subsection{Comparações entre as áreas}

A comparação entre as áreas de bandas de amostras ósseas irradiadas e não irradiadas com diferentes densidades de energia evidencia uma redução significativa na área da banda da água $\left(3700-2000 \mathrm{~cm}^{-1}\right)$ e da banda da amida I e água $\left(1642 \mathrm{~cm}^{-1}\right)$ após as irradiações, como pode ser visto na FIG. 52 e FIG 54, o que indica a diminuição da quantidade destes componentes promovida pela irradiação laser. Resultados semelhantes foram obtidos na irradiação do esmalte e dentina com laser de Er:YAG, materiais estruturalmente semelhantes ao tecido ósseo. Na dentina foi constada a perda de água e amidas, e no esmalte a irradiação afetou a matriz inorgânica ${ }^{42}$, presente em maior proporção neste material. Em tecido ósseo foi relatado a diminuição no conteúdo de amidas e $\mathrm{OH}^{-}$ após irradiação com o laser de Er:YAG com densidade de energia maior que o limiar de ablação ${ }^{14}$. No mesmo estudo, foi constado que a ablação com o laser de $\mathrm{CO}_{2}$ promove um maior decréscimo no conteúdo de amidas e $\mathrm{OH}^{-}$, o que indica que a perda de material orgânico está relacionada com a aumento de temperatura no tecido, maior com o laser de $\mathrm{CO}_{2}$ que com o Er:YAG ${ }^{14}$.

Nos resultados foi encontrada diferença significava entre os grupos irradiados, mas é possível notar uma tendência de diminuição gradativa das áreas com o aumento da densidade de energia. Variação semelhante foi reportada na irradiação com diferentes densidade de energia do esmalte e dentina com o laser de Er:YAG ${ }^{42}$

A perda de água é esperada, visto que o comprimento de onda do laser de Er,Cr:YSGG é fortemente absorvido por esse componente, como mostrado na 
FIG. 4, sendo a água responsável pela corte ósseo, já que está atua como um explosivo no processo de ablação térmica ${ }^{66}$. A perda de material orgânico também é esperada, conforme relatado em estudos com o laser de Er,Cr:YSGG e Er:YAG ${ }^{53,59,60,65,67}$.

Na banda $1642 \mathrm{~cm}^{-1}$ ocorre a sobreposição das bandas de absorção da amida I e da água e, por isso, não é possível estabelecer se a diminuição de área observada é devido apenas à perda de água, amida I, ou ambos. Entretanto, para os demais componentes orgânicos do tecido ósseo (amida II e amida III), não foram observadas diferenças significativas entre as amostras não irradiadas e as irradiadas com 2,7 J/cm² (menor densidade de energia utilizada na irradiação); contudo, para esta mesma densidade de energia, observou-se significativa redução do conteúdo de água $\left(3700-2000 \mathrm{~cm}^{-1}\right)$. Isso indica que, pelo menos para o grupo irradiado com $2,7 \mathrm{~J} / \mathrm{cm}^{2}$, a diferença de água observada provavelmente se deve exclusivamente à desidratação, e a partir dos grupos irradiados com densidades de energia superiores a $5,7 \mathrm{~J} / \mathrm{cm}^{2}$, pode ter ocorrido ambas as perdas de água e amida I.

Para as bandas de amida II e carbonato $\left(1555 \mathrm{~cm}^{-1}\right)$, amida III $\left(1240 \mathrm{~cm}^{-1}\right)$, e colágeno $\left(1203 \mathrm{~cm}^{-1}\right)$ os resultados mostram diferença significava entre as amostras não irradiadas e irradiadas com densidade de energia iguais ou maiores que $5,7 \mathrm{~J} / \mathrm{cm}^{2}$, não sendo encontradas diferenças entre as amostras não irradiadas e irradiadas com densidade de energia de 2,7 J/cm² (Grupo 2), nem entre as amostras do Grupo 2 e as amostras irradiadas com densidade de energia maiores. Como ocorreu anteriormente na banda da água e amida I, é possível notar uma diminuição das áreas sob as bandas analisadas com o aumento da densidade de energia. Além disso, considerando-se o fato das amostras do grupo $2\left(2,7 \mathrm{~J} / \mathrm{cm}^{2}\right)$ não apresentarem diferença estatística quando comparadas às amostras não irradiadas e irradiadas com densidade de energia maiores, isto reforça a hipótese da perda gradativa dos componentes com o aumento da irradiação, o que já foi mencionado anteriormente na literatura ${ }^{17,42,54}$.

Assim como o ocorrido para a sobreposição das bandas de amida I e água reportado acima, no caso da sobreposição das bandas de amida II e carbonato 
não podemos afirmar qual dos componentes teve o seu conteúdo reduzido. Entretanto, é mais provável que tenha ocorrido perda de amida II nas amostras, uma vez que o carbonato é termicamente mais estável que os compostos orgânicos ${ }^{42}$, como pode ser visto na FIG.6. No grupo 2, as amostras foram irradiadas com densidade de energia de $2,7 \mathrm{~J} / \mathrm{cm}^{2}$, inferior ao limiar de ablação para o tecido ósseo que é aproximadamente $5 \mathrm{~J} / \mathrm{cm}^{2}{ }^{34}$ Conforme pode ser observado nos resultados deste trabalho, as amostras do grupo 2 apresentaram perda de água estatisticamente significante quando comparadas às amostras não irradiadas, o que não pode ser evidenciado quanto aos demais componentes orgânicos Desta maneira, infere-se que a densidade de energia utilizada promove apenas o aquecimento da amostra, insuficiente para causar ablação ou alterações químicas significativas, mas capaz de provocar redução no conteúdo de água.

Diferentemente do que se esperava o conteúdo de colágeno (bandas 1335 $\mathrm{cm}^{-1}$ e $1285 \mathrm{~cm}^{-1}$ ) não apresentaram diferença significativa entre as amostras irradiadas com diferentes densidades de energia. Entretanto, foi observada uma tendência de diminuição das áreas com o aumento da densidade de energia utilizada. O colágeno, assim como as amidas, faz parte da matriz orgânica do osso e é de fácil desnaturação com o aumento de temperatura ${ }^{42,53}$ (como pode ser verificado na FIG. 6). A banda $1335 \mathrm{~cm}^{-1}$ está sobreposta a uma banda de carbonato $\left(1410 \mathrm{~cm}^{-1}\right)$, componente termicamente mais estável, e que pode ter influenciado na área sob a banda do colágeno encontrada. O mesmo raciocínio pode ser aplicado a banda $1285 \mathrm{~cm}^{-1}$, também próxima a banda de carbonato. Esta hipótese é reforçada visto que para as amidas e para a banda $1203 \mathrm{~cm}^{-1}$ também relativa à estrutura colágena há diferença entre os grupos irradiados com densidade de energia maiores que a densidade de energia do limiar de ablação.

As bandas do carbonato, localizadas em $870 \mathrm{~cm}^{-1}$ e $1445 \mathrm{~cm}^{-1}$, não apresentaram diferença significativa entre os grupos e nenhuma tendência é observada, enquanto a banda de carbonato localizada em $1410 \mathrm{~cm}^{-1}$ apresenta o mesmo comportamento da amida III, ou seja, as amostras irradiadas com densidade de energia superior ao limiar de ablação apresentam conteúdo de carbonato estatisticamente menor do que as amostras naturais. O carbonato é 
termicamente mais estável que os compostos orgânicos ${ }^{42}$ e, portanto, mais resistente ao aumento de temperatura do tecido do que as amidas. Desta maneira, os resultados encontrados para as bandas em $870 \mathrm{~cm}^{-1}$ e $1445 \mathrm{~cm}^{-1}$ são esperados $^{42,64}$.

A banda do carbonato localizada em $1410 \mathrm{~cm}^{-1}$ encontra-se sobreposta a uma banda correspondente à estrutura colágena $\left(1335 \mathrm{~cm}^{-1}\right) \mathrm{e}$, portanto, é provável que a perda de carbonato observada seja devido à desnaturação do colágeno com o aumento de densidade de energia e consequente aumento de temperatura, e não devido à perda de carbonato. Este fato é reforçado por resultados na literatura, que relatam o aumento de conteúdo de carbonato na irradiação de esmalte dental com o laser de $\mathrm{Er}, \mathrm{Cr}_{\mathrm{Y}} \mathrm{YSGG}^{54}$. O esmalte, assim como a dentina, possui menor estrutura orgânica quando comparado ao osso, sendo, portanto a banda $1335 \mathrm{~cm}^{-1}$ devido principalmente a vibração do carbonato, e não da estrutura colágena. Sabe-se que aumento de temperatura causada pela irradiação promove a incorporação de carbonato à hidroxiapatita ${ }^{54}$. No esmalte, que possui pouco material orgânico, é verificado a incorporação do carbonado, e portanto o aumento da área da banda; no osso, que possui material orgânico em maior quantidade, é verificado a diminuição da banda, devido a desnaturação do colágeno com o aumento de temperatura.

Não foi observada nenhuma diferença significativa entre os grupos deste estudo e nenhuma tendência para a banda correspondente à vibração $v_{4}$ do fosfato $\left(595 \mathrm{~cm}^{-1}\right)$, indicando que a irradiação laser realmente não interfere no conteúdo deste componente do tecido ósseo, conforme sugerido em estudos realizados com esmalte e dentina ${ }^{13,17,42}$. Como anteriormente mencionado, o fosfato é o componente termicamente mais estável entre os que compõem o tecido ósseo, portanto, não seria esperada alteração em seu conteúdo com a irradiação com o laser de Er,Cr:YSGG. O fato desta banda não ter sofrido alteração reforça a escolha correta do uso da área sub a banda do fosfato para a normalização dos espectros, possibilitando a análise semiquantitativa. 
Por fim, a banda correspondente à libração $\mathrm{OH}^{-}\left(676 \mathrm{~cm}^{-1}\right)$, diferentemente da banda da água, apresentou redução significativa em seu conteúdo quando irradiada com densidade de energias superiores ao limiar de ablação do osso, ou seja, a partir dos grupos irradiados com $5,7 \mathrm{~J} / \mathrm{cm}^{2}$. Entretanto, o grupo irradiado com $2,7 \mathrm{~J} / \mathrm{cm}^{2}$ não apresenta diferença estatisticamente significante com os grupos irradiados e com o grupo das amostras irradiadas, indicando uma perda gradativa do conteúdo desta banda com o aumento da densidade de energia.

Os resultados encontrados indicam que a irradiação laser em densidades de energias superiores ao limiar de ablação do tecido ósseo promoveram mudanças composicionais ao tecido remanescente. Essas mudanças indicam que o tecido foi exposto a uma temperatura suficiente para causar a desnaturação do colágeno, indicada pela perda do conteúdo de amidas e colágeno, e a desidratação do tecido (evaporação da água). Estes resultados concordam com resultados relatados na literatura para o esmalte e dentina ${ }^{13,67}$ Estas perdas sugerem que a superfície remanescente após a ablação provavelmente atingiu temperaturas iguais ou maiores que $100{ }^{\circ} \mathrm{C}$ ou mais, uma vez que tanto a ebulição da água quanto a desnaturação do colágeno ocorrem em temperaturas superiores a $100{ }^{\circ} \mathrm{C}^{17,53}$.

$\mathrm{Na}$ avaliação semiquantitativa das bandas da amida I e água, apesar de não terem sido constatadas diferenças estatísticas ente as amostras irradiadas com diferentes densidades de energia, há indicativos que as mudanças estruturais são maiores quanto maior a densidade de energia utilizada. O mesmo se aplica as bandas de $\mathrm{OH}$-, amida II , amida III e colágeno $\left(1203 \mathrm{~cm}^{-1}\right)$, que não apresentaram diferenças estatisticamente significantes entre os grupos irradiado com densidade de energia maior ou igual a $5,7 \mathrm{~J} / \mathrm{cm}^{2}$ Estes resultados corroboram os achados de estudos prévios da literatura que utilizaram o laser de Er,Cr:YSGG na irradiação de outros tecidos calcificados, como esmalte ou dentina, também constataram que as mudanças químicas induzidas nos tecidos irradiados aumentam com o aumento da densidade de energia ${ }^{13,17,42}$.

Considerando os resultados deste estudo, podemos concluir que quando tecido ósseo é cortado por irradiação com o laser de Er,Cr:YSGG esta causa 
alterações na composição química do tecido ósseo remanescente. As mudanças químicas induzidas pela irradiação com o laser podem modificar o processo de regeneração dependendo da temperatura atingida, conforme reportado na literatura ${ }^{34,35,39}$, devido principalmente à diminuição de material orgânico no tecido remanescente. Essas mudanças poderiam causar um retardo no processo de regeneração após o corte a laser. . Por outro lado, as mudanças promovidas são devido apenas à geração de calor pelo laser no tecido, fenômeno também provocado por instrumentos rotatórios mecânicos, como discos ou brocas diamantadas Portanto, ainda se faz necessária a avaliação do processo de cicatrização de tecidos cortados a laser de forma padronizada e comparando-se com métodos tradicionais, de forma a se estabelecer as vantagens de cada métodos e, com isso, sugerir um protocolo clínico seguro para a utilização da irradiação laser para o corte de tecido ósseo.

Os resultados encontrados auxiliam no entendimento da interação da radiação laser com o tecido ósseo. As alterações caudadas pela irradiação não descredenciam o uso do laser de Er,Cr:YSGG, uma vez que as irradiações foram realizadas sem a refrigeração das amostras e mesmo assim, não prejudicam a capacidade regenerativa do tecido, pois todos os componentes ainda foram identificados e não observou-se aumento de temperatura suficiente para ter afetado a matriz inorgânica do tecido ósseo. 


\section{CONCLUSÃO}

A técnica espectroscópica ATR-FTIR se mostrou uma ferramenta eficaz na caracterização de tecido ósseo. As melhores condições do equipamento espectrômetro de absorção no Infravermelho por Transformada de Fourier para a análise de amostras ósseas com $100 \mu \mathrm{m}$ de espessura foram determinadas, sendo que a melhor qualidade de sinal dos espectros foi obtida com resolução de $4 \mathrm{~cm}^{-1}, 40$ varreduras por espectro e velocidade do espelho móvel de 0,6329 $\mathrm{cm} / \mathrm{s}$. Verificou-se a impossibilidade de utilizar o método da segunda derivada para a localização das bandas, além da necessidade de normalização dos espectros para realizar uma análise semiquantitativa.

Foi possível avaliar os efeitos na composição do tecido ósseo caudados pela irradiação com o laser de Er,Cr:YSGG. Verificando-se perda gradativa das amidas, colágeno, e água conforme o aumento da densidade de energia empregada, consequência do aumento de temperatura que a irradiação laser causa ao tecido. 


\section{ANEXO A - Principais publicações e prêmios referentes ao trabalho desenvolvido}

1) ASLMS Student Travel Grant

2) RABELO, J.S.; BENETTI, C; ANA, P.A; VALÉRIO, M.E.G.; ZEZELL, D.M. Changes in Dental Enamel oven Heated or Irradiation with Er,Cr:YSGG Laser. Analysis by FTIR. Laser Physics, v.20, n. 4, p. 871-875, 2010.

3) Zezell, D.M.; Ana, P.A.; Benetti, C.; Goulart, V.P.; Bachmann, L.; Tabchoury, C;P.M; Cury, J.A. Compositional and crystallographic changes on enamel when irradiated by Nd:YAG or Er,Cr:YSGG lasers and its resistance to demineralization when associated with fluoride. SPIE Proceedings, v. 7549, p. 75490G(1-12), 2010. 


\section{REFERÊNCIAS BIBLIOGRÁFICAS} ${ }^{1}$ PEAVY, G.M.; REINISCH, L.; PAYNE, J.T; VENUGOPALAN, V. Comparison of Cortical Bone
Ablation by Using Infrared laser Wavelengths 2.9 to $9.2 \mu \mathrm{m}$. Laser in Surgery and Medicine, v.
26, p. 421-434, 1999.

${ }^{2}$ SPENCER, P.; PAYNE, J.M.; COBB, C.M.; REINISCH, J.; PEAVY, G.M.; DRUMMER, D.D.; SUCHMAN, D.L.; SWAFFORD, J.R. Effective Laser Ablation of Bone Based on the Absorption Characteristics of Water and Proteins. J. Periodontol. v. 70, n.1, p.68-74, 1999.

${ }^{3}$ ABOUZGIA, M.B.; JAMES, D.F. Temperature Rise During Drilling Though Bone. The International Journal of Oral \& Maxillofacial Implants. v. 12, n. 3, p.342-353, 1997.

${ }^{4}$ WANG, W.; ZHANG, C.; MATSUMOTO, K. In vivo study on the healing processes that occur in the jaws of rabbits following perforation by an Er,Cr:YSGG laser. Lasers in Medical Science, $v$. 20, p. 21-27, 2005.

${ }^{5}$ BELTRANO, J.J.; TORRISI, L.; CAMPAGNA, E.; RAPISARDA, E.; FINOCCHIARO, I.; OLIVI, G. Er,Cr:YSGG Pulsed laser applied to medical dentistry. Radiation Effects \& Defects in Solids, v. 163, n. 4-6, p. 331-338, 2008.

${ }^{6}$ DODICK, J.M.; LALLY, J.M.; SPERBER, L.T.D. Laser in Cataract Surgery. Current Opinion in Ophthalmology, v. 4, n. 1, p. 107-109, 1993.

${ }^{7}$ WANG, X.; ISHIZAKI, N.T.; SUZUKI, N., KIMURA, Y; MATSUMOTO, K. Morphological Changes of Bovine Mandibular Bone Irradiated by Er,Cr:YSGG Laser: An in Vitro Study. J. of Clinical Laser Medicine \& Surgery, v. 20, n.5, p. 245-250, 2002.

${ }^{8}$ ANA, P.A.; BACHMANN, L.; ZEZELL, DM. Lasers Effects on Enamel for Caries Prevention. Laser Physics, v. 16, n. 5, p.865-875, 2006.

${ }^{9}$ KIMURA, Y.; YU, D.; FUJITA, A.; YAMASHITA, A.; MURAKAMI, Y., MATSUMOTO, K. Effects of Erbium, Chromium:YSGG Laser Irradiation on Canine Mandibular Bone. J. Periodontol, v. 72, n, 9, p. 1178-1182, 2001.

${ }^{10}$ STOCK, K.; HIBST, R.; KELLER, U. Comparison of Er:YAG and Er:YSGG ablation of dental hard tissues. SPIE Proceedings, v. 3192, p. 88-95, 1997.

${ }^{11}$ IVANOV, B.; HAKIMIAN, A.M.; PEAVY, G.M.; HAGLUND JR, R.F. Mid-infrared laser ablation of hard biocomposite material: mechanistic studies of pulse duration of interface effects. Applied Surface Science, v. 208-209, p. 77-84, 2003.

${ }^{12}$ SPENCER, P.; TRYLOVICH, D.J.; COBB, C.M. Chemical Characterization of Lased Root Surfaces Using FTIR Photoacoustic Spectroscopy. J. Periodontol; v. 63, n. 7, p.633, 1992.

${ }^{13}$ RABELO, J.S.; BENETTI, C; ANA, P.A; VALÉRIO, M.E.G.; ZEZELL, D.M. Changes in Dental Enamel oven Heated or Irradiation with Er,Cr:YSGG Laser. Analysis by FTIR. Laser Physics, v.20, n. 4, p. 871-875, 2010.

${ }^{14}$ SASAKI, S.K.; AOKI,K.M.; MASUMO, A.; ISHINOSE, S.; YAMADA, S.; ISHIKAWA I. Compositional analysis of root cementum and dentin after Er,YAG laser irradiation compared with $\mathrm{CO}_{2}$ lased and intact root using Fourier transformed infrared spectroscopy. J. Periodontal Research, v. 37, p. 50-59, 2002.

${ }^{15}$ SILERSTEIN, R.M.; WEBSTER, F.X., Spectrometric Identification Of Organic Compounds. Infrared Spectrometry. USA: John Wiley \& Sons, 2005. 
${ }^{16}$ BACHMANN, L.; DIEBOLDER, R.; HIBST, R.; ZEZELL, D.M. Infrared Absorption Bands of Enamel and Dentin Tissues from Human and Bovine Teeth. Applied Spectroscopy Reviews, v. 38, n. 1, p. 1-14, 2007.

${ }^{17}$ BACHMANN, L.; DIEBOLDER, R.; HIBST, R.; ZEZELL, D.M. Changes in Chemical Composition and Collagen Structure of Dentine tissue after erbium laser irradiation. Spectrochimica Acta Part A, v. 61, p. 2634-2639, 2005.

${ }^{18}$ BOSKEY, A.; CAMACHO, N.P. FT-IR imaging of native and tissue-engineered bone and cartilage. Biomaterials, v.28, p. 2465-2478, 2007.

${ }^{19}$ BOSKEY, A.; MENDELSOHN, R. Infrared analysis of bone in health and disease. Journal of Biomedical Optics, v. 10, n.3, p.(031102)1-9, 2005.

${ }^{20}$ PIENKOWSKI, D.; DOERS, T.M.; MONIER-FAUGERE,M.; GENG, Z.; CAMACHO, N.P.; BOSKEY. A.L.; MALLUCHE, H.H. Calcitonin Alters Bone Quality in Beagle Dogs, J. of Bone and Mineral Research, v.21, n. 11, p.1936-1943, 1997.

${ }^{21}$ GADALETA, S.; LANDIS, W.J.; BOSKEY, A.L.; MENDELSOHN, R. Polarized FT-IR Microscopy of Calcified Turkey Leg Tendon. Connective Tissue Research, v. 34, n. 4, p. 203-211, 1996.

${ }^{22}$ PASCHALIS, F.B.; DICARLOS, E.; MENDELSOHN, R.; BOSKEY, A.L. FTIR Microspectroscopic Analysis of Human lliac Crest Biopsies from Untreated Osteoporotic Bone. Calcif. Tissue Int. v. 61, p. 487-492, 1997.

${ }^{23}$ ANTUNES, A.; SALVADOR, V.L.R.; SCAPIN, M.A.; DE ROSSI, W.; ZEZELL, D.M. Nanosecond $\mathrm{Nd}$ :YAG laser on dental enamel: compositional analysis by X-ray fluorescence. Laser Physics Letters, v.2, n. 6, p. 318-323, 2005.

${ }^{24}$ FEATHERSTONE, J.D.B.; FRIED, D. Fundamental Interactions of Lasers with Dental Hard Tissues. Medical Laser Applications, v.16, p.181-194, 2005.

${ }^{25}$ JUNQUEIRA, L.C.; CARNEIRO, J. Histologia Básica. Rio de Janeiro: Guanabara Koogan, 1995.

${ }^{26}$ GIANFRANTE, G.; D'ELIA, M.; QUARTA, G.; VALLI, L.; CALCAGNILE, L.. Qualitative application base on IR spectroscopy for bone sample quality control in radiocarbon dating. Nucl. Instr. And Meth. In Phys. Res. B, v.259, p.316-319, 2007.

${ }^{27}$ YACKER, M.J.; KLEIN, M. The Effect of Irrigation on Osteotomy Depth and Bur Diameter. JOMI, v. 11, p. 634-638, 1996.

${ }^{28}$ Imagem de instrumento de corte. Disponível em:

<http://www.revistahospitaisbrasil.com.br/perfil_detalhe.asp?id_perfil=115>. Acesso: Fev. 2010

${ }^{29}$ Imagem de instrumento de corte. Disponível em:

<http://www.odontologiabrasileira.com.br/wp-content/uploads/71.jpeg>

${ }^{30}$ KANG, H.W.; LEE, H.; CHEN, S.; WELCH, A.J. Enhancement of Bovine Bone Ablation Assisted by a transparent Liquid Layer on a Target Surface. IEEE Journal of Quantum Electronics, v. 42, n. 4, p. 633-642, 2006.

${ }^{31}$ BUCHEL, T, M.; KUTSCGERA, H.P.; KATTERSCHAFKA, T.; KISS, H.; LANG, S.; BEER, R.; LOSERT, U. ErB:YAG AND Hol:YAG laser osteotomy: the effect od laser ablation on bone healing. Laser Surgery and Medicine, v.15, p. 373-381, 1994. 
${ }^{32}$ MCDAVID, V.G.; COBB, C.M.; RAPLEY, J.W.; GLAROS, A.G.; SPENCER, P. Laser irradiation of bone: III. Long-term healing following treatment by $\mathrm{CO}^{2}$ and Nd:YAG lasers. J. Periodontol, v. 72, p.174-182, 2001.

${ }^{33}$ ZEZELL, D.M; MALDONADO; E.P.; RIBEIRO, M.S. Apostila Mestrado Profissionalizante: “Lasers em Odontologia"-Interação da Luz Laser com Tecidos Biológicos: Aplicações. 10 Ed. IPEN e Faculdade de Odontologia da Universidade de São Paulo. 2010.

${ }^{34}$ POURZARANDIAN, A.; WATANABE, H.; AOKI, A.; ICHINOSE, S.; SASAKI, K.M.; NITTA, H.; ISHIKAWA, I. Histological and TEM examination of early stages of bone healing after Er:YAG laser irradiation. Photomed Laser Surg., v. 22, p. 342-350, 2004

${ }^{35}$ NELSON, J.S., ORENSTEIN, A.; LIAW, L.H.; BERNS, M.W. Mid-infrared erbium:YAG laser ablation of bone: The effect of laser osteotomy on bone healing. Lasers Surg. Med., v. 9, p. 362374, 1989.

${ }^{36}$ KNAPPE, V.; KRANK, F.; ROHDE, E. Principles od Lasers and Biophotonic Effects. Photomedicine and Laser Surgery, v. 22. N. 5, p. 411-417, 2004.

${ }^{37}$ JOVANOVIC, S.; SCHONFELD, U.; PRAPAVAT, V.; BERGHAUS, A.; FISCHER, R.; SCHERER, H.; MULLER, G. Effects of Pulse laser Systems on Stapes Footplate. Laser Surg Med, v. 21, p. 341-350, 1997.

${ }^{38}$ EL MONTASER, M.A.; DEVLIN, H.; SLOAN, P.; DICKINSON, M.R. Pattern of healing of calvarial bone in the rat following application of the erbium-YAG laser. Lasers in Surgery and Medicine, v.21, n. 3, p. 373-381, 1997.

${ }^{39}$ LEWANDROWSKI, K.U.; LORENTE, C.; SCHOMACKER, K.T.; FLOTTE, T.J; WILKES, J.W.; DEUTSCH, T.F. Use of the Er:YAG laser for improved plating in maxillofacial surgery: Comparison of bone healing in laser and drill osteotomies. Lasers Surg. Med., v. 19, p. 40-45, 1996.

${ }^{40}$ YOSHINO, Y., AOKI, A.; ODA, S.; TAKASAKI, A.A.; MIZUTANI, K.; SASAKI, K.M.; KINOSHITA,A.; WATANABE, I.; IZUME, Y. Long-Term Histologic Analysis of Bone Tissue Alteration and Healing Following Er:YAG Laser Irradiation Compared to Electrosurgery. J. Periodontol, v. 80, p.82-92, 2009.

${ }^{41}$ ERIKSSON, R.A.; ALBREKTSSON, T. The Effects of heat on bone regeneration : An experimental study in the rabbit using the bone growth chamber. J. Oral Maxillofac. Surg., v. 42, p. $705-711,1984$.

${ }^{42}$ BACHMANN, L.; ZEZELL, D.M. Estrutura e Composição do Esmalte e da Dentina, Tratamento térmico e Irradiação Laser. 1.ed. São Paulo, Ed. Livraria da Física, 2005.

${ }^{43}$ GRIFFITHS, D.J. Introduction to electrodynamics, 3 Ed. Brasil. Editora Prentice-Hall do Brasil Ltda, 1999

${ }^{44}$ Imagem onda eletromagnética. Disponível em:

<http://www.fernando.tavares.nom.br/astronomia/fisica.htm>. Acesso em Fev.2010

${ }^{45}$ SKOOG, D.A.; HOLLER, F.J.; NIEMAN, T.A. Principles of Instrumental Analysis. 5 Ed. USA: Harcocourt Brace College Publishers, 1998. 
${ }^{46}$ DYER, J.R. Aplicações da espectroscopia de absorção aos compostos orgânicos. Trad. Sob a direção de Aurora Giora Albanese. São Paulo, Editora Edgard Blucher Ltda. 1969.

${ }^{47}$ STUART, B. Biological Applications of Infrared Spectroscopy. 1Ed. Inglaterra: John Wiley \& Sons: 1997.

${ }^{48}$ ALBERO, F.G. Diagnóstico de lesões da tireoide pela espectroscopia de absorção no infravermelho por transformada de Fourier - FTIR. 2010. Dissertação (Mestrado) - Instituto de Pesquisa Energéticas e Nucleares, São Paulo.

${ }^{49}$ GENITA, E.A.; BASHKATOV, A.N.; TUCHIN, V.V. Optical Clearing of cranial Bone. Advances in Optical Technologies, v. 208; n. 267867 p. 1-8.

${ }^{50}$ LIMA, S.M; IZIDA, T.; FIGUEIREDO M.S; L. H.C. ANDRADE L.H.C.; DEL RÉ, P.V.; JORGE, N.; BUBA E.;.ARISTONE, F. Analysis of biodiesel and frying vegetable oils by means of FTIR photoacoustic spectroscopy. The European Physical Journal - Special Topics,v. 153, n.1, p.535-537, 2008.

${ }^{51}$ GOSTIC, T.; KLEMENC, S.; Evidence on unusual way of cocaine smuggling: Cocainepolymethyl methacrylate (PMMA) solid solution—study of clandestine laboratory samples. Forensic Science International, v. 169, n-1-4, p.1=210-219, 2006.

${ }^{52}$ SINELLI, N.; CASIRAGHI. E.; DOWNEY, G. Studies on Proofing of Yeasted Bread Dough Using Near- and Mid-Infrared Spectroscopy. J. of Agricultural and Food Chemistry, v. 56, p. 922-931, 2008.

${ }^{53}$ BACHMANN, L.; GOMES, A.S.L.; ZEZELL, D.M. Collagen absorption band in heated and rehydrated dentine. Spectrochimica Acta Part A, v. 62, p.1045-1049, 2005.

${ }^{54}$ RABELO, J.S. Hidroxiapatita Sintética Nanoestruturada e Esmalte Dental Aquecido e Irradiado por Laser de Er,Cr:YSGG. Caracterização por FTIR e por DRX. 2009. Dissertação (Mestrado) - Instituto de Pesquisa Energéticas e Nucleares, São Paulo.

${ }^{55}$ REY, C., SHIMIZU, M., COLLINS, B., GLIMCHER, M.J. Resolution-Enhanced Fourier Transform Infrared Spectroscopy Study of the Environment of Phosphate lons in the Early Deposits of a Solid Phase of Calcium-Phosphate in Bone and Enamel, and their Evolution with Age. I: Investigations in the $v_{4} \mathrm{PO}_{4}$ Domain. Calcif. Tissue.Int. v. 43, p. 384-394, 1990.

${ }^{56}$ EMERSON, W.H., FISCHER, E.E. The Infra-Red Absorption Spectra of carbonate in Calcified Tissues. Arch. Oral Biol. v. 7, p. 671-683, 1962.

${ }^{57}$ SASAKI, S.K.; AOKI,K.M.; MASUMO, A.; ISHINOSE, S.; YAMADA, S.; ISHIKAWA I.

Compositional analysis of root cementum and dentin after Er,YAG laser irradiation compared with $\mathrm{CO}_{2}$ lased and intact root using Fourier transformed infrared spectroscopy. J. Periodontal

Research, v. 37, p. 50-59, 2002.

${ }^{58}$ STOCH, A.; JASTRZEBSKI, W.; BROZEK, A.; STOCH, J.; SZARANIEC, J.; TRYBALSKA, B.; KMITA, G. FTIR absorption-reflection study of biomimetic growth of phosphate on titanium implants. Journal of Molecular Structure. v. 555, p. 375-382, 2000.

${ }^{59}$ FEATHERSTONE, J.D.B.; NELSON, D.G.A. Laser effects on dental hard tissue. Adv. Dent. Res, v.1, p.21-26, 1987. 
${ }^{60}$ FOWLER, B.O.; KURODA, S.; Changes in heated and in laser-irradiated human tooth enamel and their probable effects on solubility. Calcified Tissue International, v.38, p.197-208, 1986.

${ }^{61}$ OSTANG, M; MCKINLEY, JT; REINISCH, L; HARRIS, DM; TOLK, NH. Laser Ablation as a Function of the Primary Absorber in Dentin. Lasers in Surg. and Med.v. 21, p.384-394, 1997.

${ }^{62}$ APEL, J.; MEISTER, R.S.; FRAZEN, P.; HERING, P.; GUTKNECHT, N. The ablation threshold of Er:YAG and Er,Cr:YSGG Laser Radiation in Dental Enamel. Laser Med. Sci. v. 17, p. 246-252, 2002.

${ }^{63}$ IZZAT, J.A.; ALBAGLI, D.; ITZKAN, I.; FELD, M.S. Pulsed laser ablation of calcified tissue: physical mechanisms and fundamental parameters. Laser-Tissue Interaction -SPIE, v. 1202, p.133-140, 1990.

${ }^{64}$ HIBST, R.; KELLER, U. Mechanism of Er:YAG laser induced ablation of dental hard substances. Lasers in Orthopedic, Dental, and Medicine II - SPIE, v. 1880, p. 156-162, 1993.

${ }^{65}$ FRIED, D.; FEATHERSTONE, J.D.B, VISURU, S.R.; SEKA, W.W.; WASLSH, J.T. The caries inhibition potencial of Er:YAG and Er,Cr:YSGG laser irradiation. In: Wigdor HA; Featherstone JDB; White JM; Neev J; Katzir A, eds. Proceedings of Laser in Dentistry II. Bellinghan, WA: Proceedings of the society of photo optical instrumentation engineers (SPIE), Inc: 1996; 2672:73-78

${ }^{66}$ BONK, P.A. Avaliação da mudança da micordureza na superfície de esmalte dentário irradiada com laser de hólmio e modelamento das microexplosões. 1999. Dissertação (Mestrado) - Instituto de Pesquisa Energéticas e Nucleares, São Paulo.

${ }^{67}$ KURODA, S.; FOWLER, B.O. Compositional, structural, and phase changes in in vitro laserirradiated human tooth enamel. J. Calcified Tissue International, v. 36, p. 361:369, 1983. 